de Ronde, C.E.J., Humphris, S.E., Höfig, T.W., and the Expedition 376 Scientists

Proceedings of the International Ocean Discovery Program Volume 376

publications.iodp.org

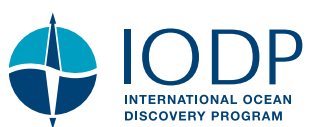

https://doi.org/10.14379/iodp.proc.376.103.2019

Check for updates

Contents

\section{Site U1527}

C.E.J. de Ronde, S.E. Humphris, T.W. Höfig, P.A. Brandl, L. Cai, Y. Cai, F. Caratori Tontini, J.R. Deans, A. Farough, J.W. Jamieson, K.P. Kolandaivelu, A. Kutovaya, J.M. Labonté, A.J. Martin, C. Massiot, J.M. McDermott, I.M. McIntosh, T. Nozaki, V.H. Pellizari, A.G. Reyes, S. Roberts, O. Rouxel, L.E.M. Schlicht, J.H. Seo, S.M. Straub, K. Strehlow, K. Takai, D. Tanner, F.J. Tepley III, and C. Zhang ${ }^{2}$

Keywords: International Ocean Discovery Program, IODP, JOIDES Resolution, Expedition 376, Brothers Arc Flux, Brothers volcano, Site U1527, Kermadec arc, submarine arc volcano, hydrothermal systems, volcaniclastics, dacite lava, hydrothermal alteration, borehole fluids, hypersaline brine, fluid inclusions, acidic fluids, alteration mineral assemblages, Upper Cone, Lower Cone, NW Caldera
1 Summary

3 Background and objectives

4 Operations

8 Igneous petrology and volcanology

15 Alteration

20 Structural geology

22 Geochemistry

28 Paleomagnetism

31 Physical properties

35 Microbiology

35 References

\section{Summary Background and objectives}

Site U1527 (proposed Site NWC-1A) is located on the rim of the NW Caldera wall of Brothers volcano at a water depth of $1464 \mathrm{~m}$. Drilling targeted what was considered to be either the margin of an older, modified seawater hydrothermal upflow zone and/or a recharge zone to the currently active discharge areas several hundred meters northwest and southeast of the drill site, respectively. A key objective of Expedition 376 was to quantify the mechanisms and extent of fluid-rock interaction and the consequences for mass transfer of metals into the ocean in both seawater-influenced and magmatically influenced hydrothermal systems in the caldera of Brothers volcano. Hence, the main objective of Site U1527 was to drill through the margin of the inferred upflow zone of a Type I (modified seawater) hydrothermal system.

\section{Operations}

We conducted operations in three holes at Site U1527. Hole $\mathrm{U} 1527 \mathrm{~A}$ is located at $34^{\circ} 51.6528^{\prime} \mathrm{S}, 179^{\circ} 3.2397^{\prime} \mathrm{E}$ at a water depth of $1464.2 \mathrm{~m}$. We used the rotary core barrel (RCB) system to core from the seafloor to 101.4 meters below seafloor (mbsf), with poor recovery of $1.27 \mathrm{~m}(1.3 \%)$. The downhole conditions encountered in Hole U1527A determined the preparations needed for running a reentry system. In Hole U1527B, located at $34^{\circ} 51.6519^{\prime} \mathrm{S}, 179^{\circ} 3.2526^{\prime} \mathrm{E}$ at a water depth of $1464.2 \mathrm{~m}, 10.75$ inch $(\sim 27.3 \mathrm{~cm})$ casing was drilled to $95.5 \mathrm{mbsf}$, with final penetration of the drilling assembly to 105.5 mbsf. Upon releasing from the casing, the reentry system hung up on the underreamer arms, which failed to retract, and the entire as- sembly returned to the surface, where it was recovered. Hole $\mathrm{U} 1527 \mathrm{C}$ is located at $34^{\circ} 51.6625^{\prime} \mathrm{S}, 179^{\circ} 3.2534 \mathrm{E}$ at a water depth of $1464.1 \mathrm{~m}$. After installing $95.5 \mathrm{~m}$ of casing, we RCB cored continuously from 99.9 to $238.0 \mathrm{mbsf}$ and recovered $25.9 \mathrm{~m}$ (19\%) of material. There was extremely poor to no recovery in unconsolidated volcanic deposits until a formation change at $187 \mathrm{mbsf}$, after which average recovery increased to $49 \%$ for the rest of coring in cemented volcaniclastic rocks. Unstable hole conditions forced abandonment of Hole U1527C, and once again the reentry system was unintentionally retrieved due to clogging of the hydraulic release tool (HRT) and upper casing sub. In total, $249.5 \mathrm{~h}$, or 10.4 days, were spent at Site U1527.

\section{Principal results \\ Igneous petrology and volcanology}

Igneous rocks cored at Site U1527 were divided into two units. Igneous Unit 1 was recovered in Hole U1527A (29.10-67.81 mbsf) and Hole U1527C (108.40-176.16 mbsf). It consists of plagioclaseclinopyroxene-phyric and Fe-Ti oxide-bearing dark gray dacite lava with a glassy trachytic groundmass and stratigraphically related unaltered scoria and pumice lapilli.

Igneous Unit 2 was recovered in Hole U1527C (185.20-234.38 mbsf). The contact between Units 1 and 2 was not recovered. Igneous Unit 2 consists of progressively hydrothermally altered volcaniclastic rocks and is divided into four subunits $(2 \mathrm{a}-2 \mathrm{~d})$ based on changes in modal composition of clasts, matrix-to-clast ratio, and color. Igneous Subunit 2a (185.20-185.44 mbsf) is lapilli-tuff consisting of fresh dacitic clasts surrounded by a brown, fine-grained matrix that probably represents altered tuff. Igneous Subunit $2 b$

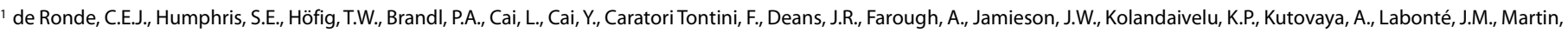
A.J., Massiot, C., McDermott, J.M., McIntosh, I.M., Nozaki, T., Pellizari, V.H., Reyes, A.G., Roberts, S., Rouxel, O., Schlicht, L.E.M., Seo, J.H., Straub, S.M., Strehlow, K., Takai, K., Tanner, D., Tepley III, F.J., and Zhang, C., 2019. Site U1527. In de Ronde, C.E.J., Humphris, S.E., Höfig, T.W., and the Expedition 376 Scientists, Brothers Arc Flux. Proceedings of the International Ocean Discovery Program, 376: College Station, TX (International Ocean Discovery Program). https://doi.org/10.14379/iodp.proc.376.103.2019

2 Expedition 376 Scientists' affiliations.

MS 376-103: Published 5 July 2019

This work is distributed under the Creative Commons Attribution 4.0 International (CC BY 4.0) license. (cc) BY
} 
(185.44-220.98 mbsf) is composed of matrix-supported monomict and polymict lapilli-tuffs, lapillistones, and tuff-breccias. Igneous Subunit 2c (220.98-226.49 mbsf) is made up of clast-supported polymict lapillistones, whereas Igneous Subunit 2d (228.40-234.38 mbsf) is composed of both altered matrix- and clast-supported tuffbreccias and lapilli-tuffs.

Igneous Unit 2 rocks contain various clasts of volcanic origin: (1) unaltered to slightly altered dacite in Subunit 2a; (2) volumetrically significant greenish gray altered volcanic clasts in Subunits $2 b$, 2c, and 2d; (3) fine-grained, dark green altered clasts in Subunit 2b; and (4) various types of rare, dark gray volcanic clasts in Subunits $2 \mathrm{~b}, 2 \mathrm{c}$, and $2 \mathrm{~d}$. The matrix of the volcaniclastic rocks and the groundmass of volcanic clasts in Igneous Unit 2 appear very similar to the trachytic groundmass of the dacite lava of Igneous Unit 1, but they are increasingly replaced by secondary chlorite, clays, and quartz with depth. All clasts contain varying amounts of plagioclase, clinopyroxene, and $\mathrm{Fe}-\mathrm{Ti}$ oxides, strongly resembling the primary phenocryst assemblage of the dacite lavas of Igneous Unit 1. Although the degree of alteration increases downhole, as indicated by the increasing degree of silicification, plagioclase crystals are only slightly altered, whereas clinopyroxene alters significantly or disappears and Fe-Ti oxides alter to sulfides. Petrography and abundance of alteration-resistant elements suggest that the protolith for altered volcaniclastic rocks in Igneous Unit 2 was dacitic, similar to unaltered dacite lavas encountered in Igneous Unit 1 and at other sites at Brothers volcano.

\section{Alteration}

Three distinct types of alteration were observed in core material recovered from Site U1527.

Alteration Type I (0-185.44 mbsf) occurs in intervals of fresh to slightly altered volcanic rocks and is characterized by low-temperature alteration mineral assemblages. This alteration type is split into two distinct Alteration subtypes: Ia and Ib. Alteration Subtype Ia (0-185.20 mbsf) consists of unaltered to slightly altered vesicular dacitic lava. Alteration is characterized by the formation of zeolite in vesicles and the occurrence of palagonite, iron oxyhydroxide, and trace pyrite partly replacing volcanic glass. Alteration Subtype Ib (185.20-185.44 mbsf) pertains solely to the volcaniclastic rocks of Igneous Subunit 2a, which are slightly to moderately altered. The clasts exhibit only trace alteration and retain primary plagioclase and clinopyroxene phenocrysts, but the degree of alteration in the matrix is greater than in Alteration Subtype Ia. The alteration material in the matrix consists of iron oxyhydroxide and illite with minor zeolite, smectite, magnetite, and pyrite.

Alteration Type II (185.72-234.38 mbsf) is characterized by more extensive alteration of most primary minerals being replaced by clay minerals, silica, and pyrite in both clasts and matrix of the volcaniclastic rocks. This alteration type is also divided into two subtypes. Alteration Subtype IIa (185.72-234.38 mbsf; intercalated with Alteration Subtype IIb and Alteration Type III) features a pervasive green-gray chlorite-smectite mineral assemblage with increasing amounts of silica/quartz infilling pore spaces and increasing abundance of disseminated pyrite with depth. The moderate to intense alteration occurs in both clasts and matrix of the primary volcaniclastic rocks. The degree of alteration in this interval increases downhole. Alteration Subtype IIb (186.40-208.06 mbsf; intercalated with Alteration Subtype IIa) is characterized by several centimeter- to meter-scale zones of yellow-brown alteration overprinting the greenish Alteration Subtype IIa. The overprinting boundary is sharp. Iron oxyhydroxide, which occurs both on its own and as an oxidized coating on pyrite, gives this alteration type its characteristic yellow-brown color. Throughout both the green and yellow-brown altered intervals, clasts display a range of degrees of alteration and resorption, from slightly altered clasts with primary igneous textures and sharp boundaries to intensely altered clasts with diffuse boundaries to the surrounding matrix.

Alteration Type III (220.98-226.49 mbsf) represents a more heterogeneous alteration type that is intercalated with Alteration Subtype IIa. In this type of alteration, both clasts and matrix are pervasively altered. The matrix contains dark gray silica and chlorite, disseminated pyrite (as much as $3 \%$ ), and magnetite. Vugs are partially filled with clay minerals and silica.

\section{Structural geology}

Site U1527 is characterized by moderately to steeply dipping alteration contacts, fractures, and faults in addition to shallowly dipping shears and relatively few alteration veins. Alteration contacts are sharp and range in dip from $0^{\circ}$ to $74^{\circ}$ (average and median $=48^{\circ}$ ), and they demarcate the Alteration Subtype IIa-IIb transition. Fractures also have a moderate to steep dip with a range from $37^{\circ}$ to $90^{\circ}$ and an average of $68^{\circ}$. The density of veins and fractures is low. Fractures almost always have a brown/orange alteration halo overprinting all other types of alteration. This alteration halo defines Alteration Subtype IIb and indicates that formation of fractures is late and/or is the focus of seawater ingress. Faults were observed only in Hole U1527C. Faults have steep dips ranging from $45^{\circ}$ to $83^{\circ}$ (average of $66^{\circ}$ ) and are most abundant in Igneous Subunit 2c. All faults represent discrete, centimeter-scale zones and have a normal sense of shear. Shallowly dipping shears are defined by elongate ribbons of white clay that may represent flattened and altered volcanic clasts. White ribbons wrap around larger volcanic clasts, which may indicate crystal-plastic deformation. The shallowly dipping shears have an average dip of $22^{\circ}$ and are overprinted by brittle faults. The overall lack of veins and the indications of fractures being late suggest that alteration is not structurally controlled and may instead be due to pervasive, hydrothermal flow.

\section{Geochemistry}

Unaltered volcanic rocks from Hole U1527A and the shallower sections of Hole U1527C (Igneous Unit 1) represent dacites that are compositionally similar to those previously reported from Brothers volcano. However, two distinctly different trend lines for fluid-immobile incompatible trace element ratios $(\mathrm{Zr} / \mathrm{Y}$ and $\mathrm{Zr} / \mathrm{Ti})$ suggest that the unaltered dacites from Holes U1527A and U1527C may derive from different magma sources.

Most of the pervasively altered volcaniclastic rocks recovered from Hole U1527C (Igneous Unit 2) share the incompatible element composition of the overlying Igneous Unit 1 from the same hole, based on $\mathrm{Zr}, \mathrm{Y}$, and $\mathrm{TiO}_{2}$ abundances. These findings indicate an origin from a common parental magma despite petrographic differences. Geochemical analyses of the highly altered, variously colored volcaniclastic rocks demonstrate the mobility of alkali metals during high- and low-temperature hydrothermal alteration of the rock. $\mathrm{Ba}, \mathrm{K}_{2} \mathrm{O}, \mathrm{Mg}, \mathrm{SiO}_{2}$, and total sulfur contents record a complex history of hydrothermal overprint marked by multiple alteration stages. Geochemical changes recorded in Hole U1527C are consistent with petrographic observations, including the formation of pyrite and replacement of groundmass and matrix by clay in deeper, more altered volcaniclastic rocks.

Organic carbon comprises the bulk of measured total carbon (TC) concentrations. Only detectable at 185-205 mbsf in Hole 
U1527C, this organic carbon may originate from seawater-derived fluid circulation and/or microbial biomass. Headspace analysis of gases evolved from the pore spaces of Hole U1527C samples indicates higher-than-ambient $\mathrm{H}_{2}$ contents that may be produced by mechanochemical sampling artifacts such as generation during RCB drilling and/or crushing rock samples prior to headspace sampling.

\section{Paleomagnetism}

The two igneous units at Site U1527 have different natural remanent magnetization (NRM) intensities before demagnetization, and Igneous Unit 1 has a more intense NRM $(>0.5 \mathrm{~A} / \mathrm{m})$ than Unit 2. However, both units show a consistent direction of magnetization with an average inclination of $-59^{\circ}$, which is very close to the inclination of a geomagnetic axial dipole (GAD) of $-55^{\circ}$ at the latitude of Brothers volcano. This consistency suggests a young age for these rocks, most certainly during the current normal polarity Brunhes geomagnetic epoch. Unit 1 also shows significantly higher magnetic coercivities. Thermal demagnetization experiments from Unit 2 show a more complex pattern than similar experiments from Unit 1 , although they consistently indicate magnetite or titanomagnetite as the main magnetic mineral in both lithologic units. In addition, susceptibility measurements and isothermal remanence magnetization experiments suggest a comparable magnetite content in both units, with a slight decrease in Subunits 2c and 2d.

\section{Physical properties}

Igneous Unit 1, which consists of fresh dacitic volcanics, shows an inverse correlation between porosity and bulk density but not between porosity and $P$-wave velocity or between bulk density and $P$-wave velocity. Igneous Unit 2 , which consists of variably altered volcaniclastic rocks, displays an inverse correlation between porosity and bulk density and between porosity and $P$-wave velocity. Mean bulk density $\left(2.2 \mathrm{~g} / \mathrm{cm}^{3}\right)$, porosity $(30 \%)$, and $P$-wave velocity $(3330 \mathrm{~m} / \mathrm{s})$ generally show small variations throughout Unit 2 and do not appear to be affected by transitions between alteration types. Alteration Subtypes IIa and IIb are clearly identifiable on reflectance colorimetry. A sharp increase in $P$-wave velocity at the boundary between Subunits 2b and 2c (velocity of $\sim 4000$ and 4200 $\mathrm{m} / \mathrm{s}$ on working halves and discrete samples, respectively) was observed, followed by a downhole decrease in $P$-wave velocity to the end of Subunit 2c. This variation in $P$-wave velocity in Subunit 2c is reflected in a similar trend in bulk density and a matching inverse variation in porosity that appears to be associated with deformation and shear in this unit.

Magnetic susceptibility (MS) measured on whole rounds and section halves is compatible with discrete measurements. MS in Igneous Subunits $2 \mathrm{a}$ and $2 \mathrm{~b}$ is higher overall than in Igneous Subunits $2 \mathrm{c}$ and $2 \mathrm{~d}$. Thermal conductivity values range from 1.09 to 2.35 $\mathrm{W} /(\mathrm{m} \cdot \mathrm{K})$ with an average of $1.72 \mathrm{~W} /(\mathrm{m} \cdot \mathrm{K})$, and Igneous Unit 2 has higher thermal conductivity values than Igneous Unit 1 . Thermal conductivity in Unit 2 also varies over smaller scales, which reflects changes in type and distribution of alteration minerals. Low thermal conductivity values occur where alteration is dominated by the presence of water-rich clay minerals (e.g., a low of $1.53 \mathrm{~W} /[\mathrm{m} \cdot \mathrm{K}]$ in Subunit $2 \mathrm{~b}$ at $\sim 203.40 \mathrm{mbsf}$ ). Meanwhile, the highest thermal conductivity value is consistent with increases in pyrite, silica, and magnetite concentrations in Subunit 2c. Hence, thermal conductivity data reflect the heterogeneity of mineral compositions and alteration assemblages throughout the core.

\section{Microbiology}

Five whole-round samples were collected from hydrothermally altered, relatively hard materials from Hole U1527C. The wholeround samples (each 11-20 cm long) were processed and preserved as subsamples for shore-based investigations, which will include quantification of microbial and viral biomass, molecular analysis of extracted environmental DNA and RNA, estimation of microbial metabolic activity and viral production, and cultivation of subseafloor microorganisms. Quantification of the contamination tracer perfluoromethyl decaline (PFMD) was conducted for the drilling fluid and for the exterior and interior of whole-round samples. PFMD was routinely detected, although barely above detection levels, indicating that penetration of drilling fluids to the interior of whole-round samples was minimal.

\section{Background and objectives}

Site U1527 is located on the rim of the NW Caldera wall of Brothers volcano at $34^{\circ} 51.6528^{\prime} \mathrm{S}, 179^{\circ} 03.2397^{\prime} \mathrm{E}$ (Figure F1) about 240 m northeast of seismic Line Bro-3 (Figure F2) at a water depth of $1464 \mathrm{~m}$. Based on an expected outward dip of the caldera-bounding faults (Embley et al., 2012) and known mineralization ages that decrease from the caldera rim to floor (de Ronde et al., 2011), drilling targeted the margin of an older Type I hydrothermal upflow zone dominated by seawater-derived fluids. Anticipated lithologies were volcaniclastic material and dacite lava. Shallow holes drilled by Neptune Minerals, Inc., located 250 m northeast and east-south-

Figure F1. Detailed bathymetry of Brothers volcano and surrounding area showing the location of sites drilled during Expedition 376. Contour interval $=200 \mathrm{~m}$. Modified from Embley et al. (2012).

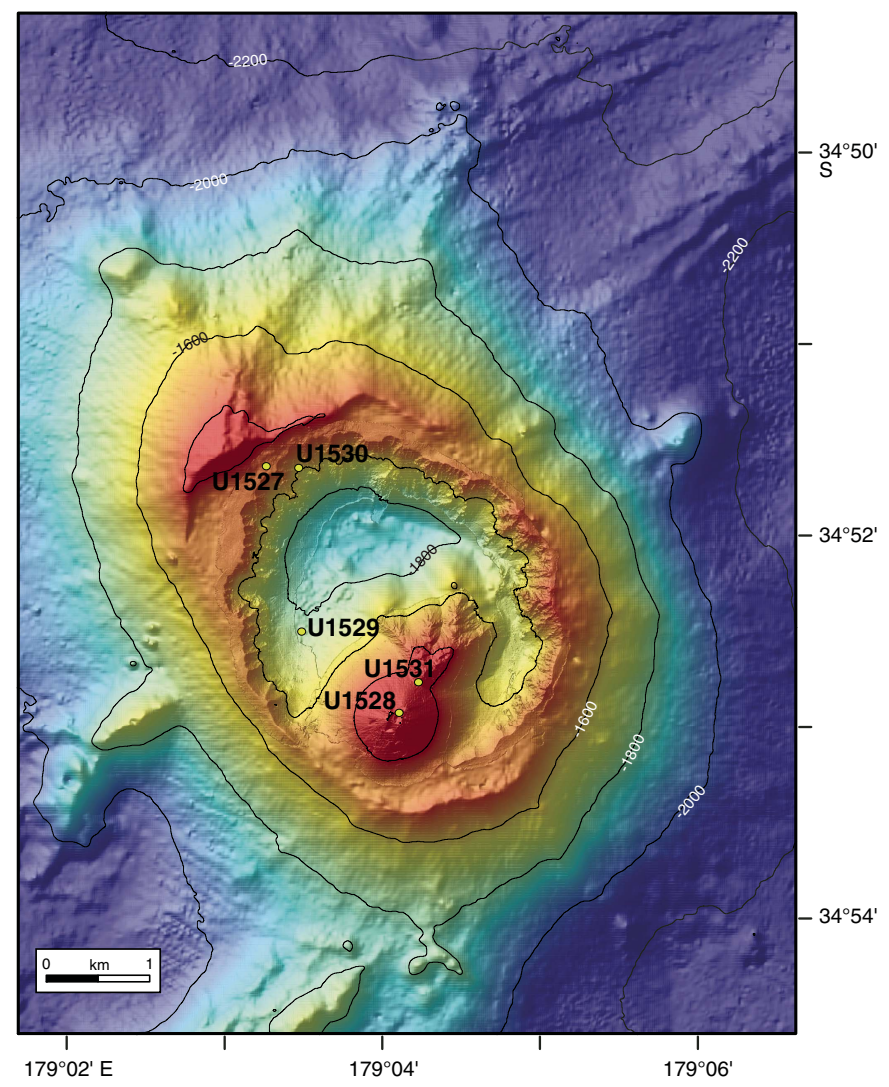


Figure F2. Seismic section along Line Bro-3 for the three proposed primary sites (NWC-1A, UC-1A, and WC-1A) and one proposed alternate site (UC-2A). The depth of a $\sim 400 \mathrm{~m}$ hole is based on a seismic velocity of $2.5 \mathrm{~km} / \mathrm{s}$; higher velocities mean deeper holes in the same section, and lower velocities mean shallower holes. Blue line = seafloor derived from bathymetric data. Proposed Site WC-1A is slightly out of the plane of the section. The two-phase zone is derived from the ocean-bottom hydrophone survey of Dziak et al. (2008).

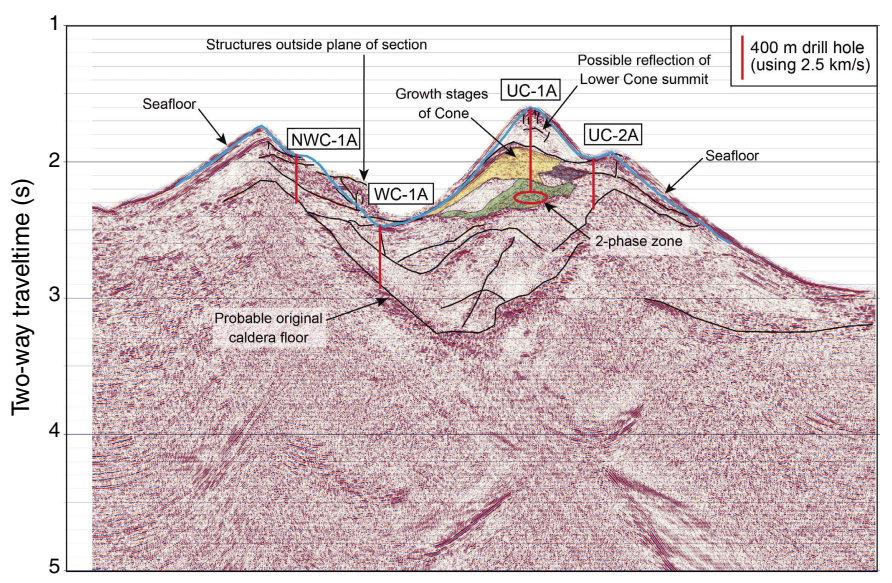

east of the site, recovered brown platy iron oxyhydroxides with varying amounts of volcanic glass in the uppermost $3 \mathrm{~m}$ in the cores.

The plan for drilling at Site U1527 was to penetrate to 400 mbsf through the margin of the inferred upflow zone and down through the footwall of the original caldera depicted in the seismic section through this area (proposed primary Site NWC-1A; Figure F2) to intersect the minimum modeled thickness estimate of $300 \mathrm{~m}$ for a zone of low crustal magnetization (Caratori Tontini et al., 2012) over this site.

\section{Operations Auckland port call}

Expedition 376 started with the first line ashore at the Freyberg Wharf B in Auckland, New Zealand, at 0652 h on 5 May 2018, which marked the end of Expedition 375. Activities on the first day of port call included boarding the Expedition 376 Co-Chief Scientists, JOIDES Resolution Science Operator (JRSO) staff, and Center for Deep Earth Exploration (CDEX) engineering staff. JRSO staff conducted the crossover with their Expedition 375 counterparts. Initial loading of incoming freight began while Expedition 375 core and sample shipments were offloaded.

On 6 May, the Expedition 376 scientists boarded the vessel, moved their luggage into their cabins, received an introduction regarding information technology, attended an initial safety orientation, and then were introduced to life on board and the science laboratories. Loading and discharge of freight continued throughout the day, including loading 83 joints of casing (10.75 and 13.375 inches), 40 joints of 5.5 inch drill pipe, and 88.5 metric tons of sepiolite.

On 7 May, the scientists and JRSO technical staff were introduced to each other, and the Co-Chief Scientists initiated the expedition with a presentation on the expedition science objectives. A second talk that addressed the science work plan was presented by the International Ocean Discovery Program (IODP) Expedition Project Manager. During the afternoon, the captain introduced key staff to the science party and gave an orientation on ship safety. All science groups then started learning their onboard laboratory tasks, including setting up applicable instruments, assisted by JRSO staff.

On 8 May, all public relation activities and loading of supplies and hardware were completed. That evening, the ship shifted to Wynyard Wharf for fueling, with the first line ashore at $1930 \mathrm{~h}$. Fueling was completed at $0400 \mathrm{~h}$ on 9 May.

\section{Transit to Site U1527}

At 0758 h on 9 May 2018, the pilot arrived on board, and the vessel departed Wynyard Wharf with the last line away at $0821 \mathrm{~h}$. Our departure was assisted by one harbor tug, and we proceeded to the pilot station, where the pilot departed the vessel at $0924 \mathrm{~h}$. We then began our transit through the Hauraki Gulf to Site U1527 at Brothers volcano. On the afternoon of 9 May, the Captain held the first fire and safety drill. During the transit, the Co-Chief Scientists met with key members of the JRSO staff and ship's crew to review the coring and logging plan for the expedition.

\section{Site U1527}

The original plan for Site U1527 was to drill two holes. The first one, a pilot hole, was designated to core to $\sim 50 \mathrm{mbsf}$ with the RCB system (Figure F3). The second hole would drill in a reentry system to a depth determined based on the pilot hole. The reentry system was supposed to allow for $405 \mathrm{~m}$ of penetration at Site U1527. Actual operations proved different from the plan, and three holes were drilled. Hole U1527A was RCB cored to 101.4 mbsf. Hole U1527B was RCB drilled to 105.5 mbsf with $95.5 \mathrm{~m}$ long casing installed but could not be reentered because the reentry system was inadvertently retracted. Hole U1527C was cased to $95.5 \mathrm{mbsf}$ and reentered with continuous RCB coring from 99 to 238 mbsf.

\section{Hole U1527A}

After completing the $24 \mathrm{~h}$ transit from Auckland $(246 \mathrm{nmi}$ at $10.6 \mathrm{kt}$ ), we arrived at Site U1527 at $0800 \mathrm{~h}$ on 10 May 2018. We picked up a new RCB coring bit with a mechanical bit release, assembled the RCB bottom-hole assembly (BHA) (Figure F4), verified the correct space-out of the core barrel, and lowered it to the seafloor. We deployed nonmagnetic core barrels throughout coring at Site U1527. The subsea camera system with the advanced piston corer temperature tool (APCT-3) shoe was lowered to the seafloor to conduct a survey, and the seafloor site marker left in 2017 by a remotely operated vehicle was quickly located. After tagging six potential hole locations to verify the water depth and the absence of vent-related animals, the subsea camera system was retrieved and the acoustic beacon was deployed. We then spudded Hole U1527A at a water depth of $1464.2 \mathrm{~m}$ at $2240 \mathrm{~h}$ on 10 May. Tracer material (PFMD) was pumped continuously while drilling. The maximum downhole temperatures were recorded by temperature strips contained in a housing tool attached to the RCB core barrel head.

Cores 376-U1527A-1R through 15R penetrated the seafloor to a final depth of 101.4 mbsf with poor recovery of only $1.27 \mathrm{~m}(1.3 \%)$ in unconsolidated volcanic deposits. The change to half-length advance $(4.8 \mathrm{~m}) \mathrm{RCB}$ coring for Cores $7 \mathrm{R}-15 \mathrm{R}$ did not improve the recovery, and all core barrels but one were empty when recovered. All cores, penetration depths, core recovery, and times recovered on deck are displayed in Table T1. Coring was terminated when we determined that the hole conditions were worsening, leading to the 
Figure F3. A. RCB coring system. ID = inner diameter, $\mathrm{OD}=$ outer diameter. B. RCB coring bit (displayed upside down). Modified from Graber et al. (2002).
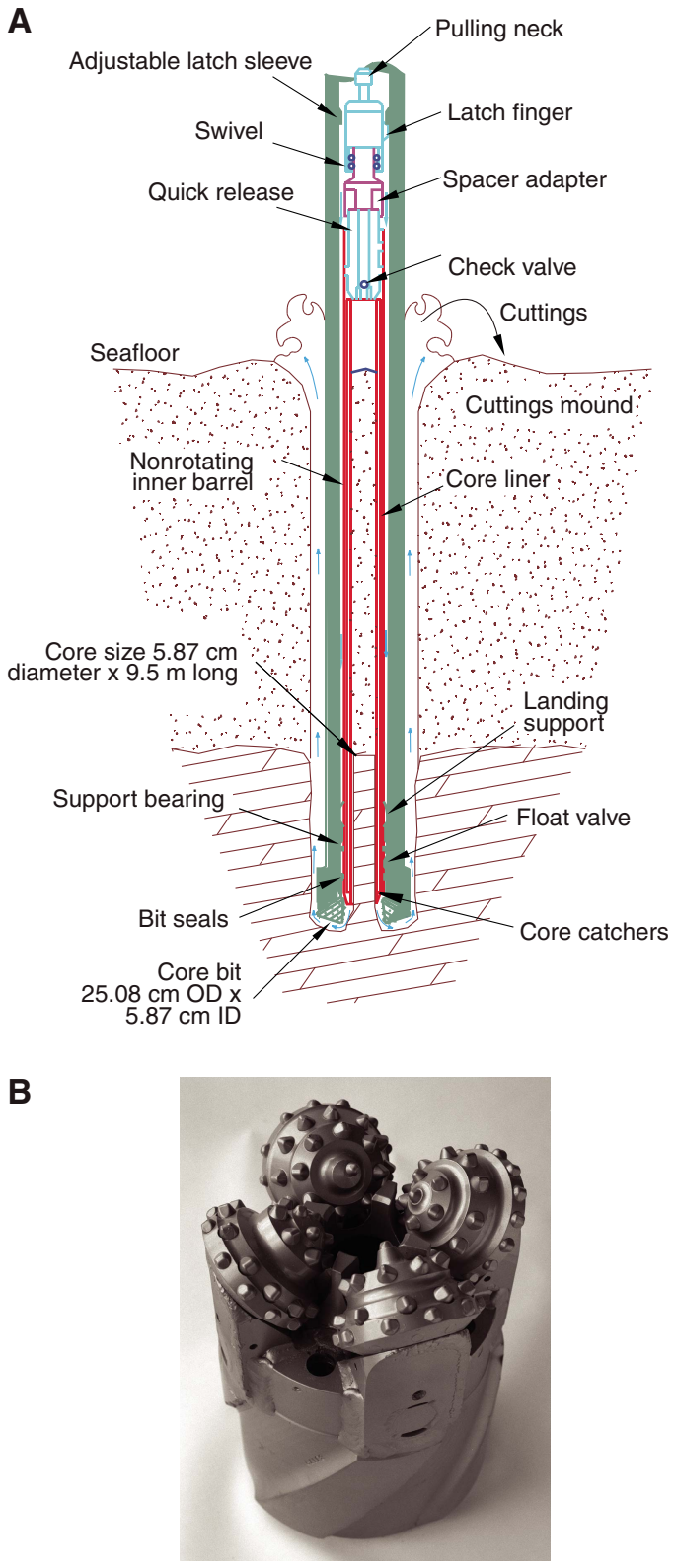

decision that $\sim 100 \mathrm{~m}$ of casing was all that could likely be installed and would be sufficient to prevent the hole from collapsing.

\section{Hole U1527B}

After completing Hole U1527A, the ship was offset 20 m east, and we started assembling a reentry system for installation in Hole U1527B to facilitate deep coring and logging objectives at this site. We assembled a $95.5 \mathrm{~m}$ long 10.75 inch casing string and a BHA consisting of a 9.875 inch $(\sim 25 \mathrm{~cm})$ tricone drill bit, an underreamer (set to 12.75 inches) (Figure F5), a mud motor, two stands of drill collars, and $23 \mathrm{~m}$ of drill pipe. The preassembled running stand with the HRT (casing running tool) was lowered to the moonpool and connected to the casing string. The reentry funnel was picked up, installed, and welded to the top casing joint together with the hard rock landing frame.
Figure F4. RCB BHA. ID = inner diameter. Modified from Graber et al. (2002).

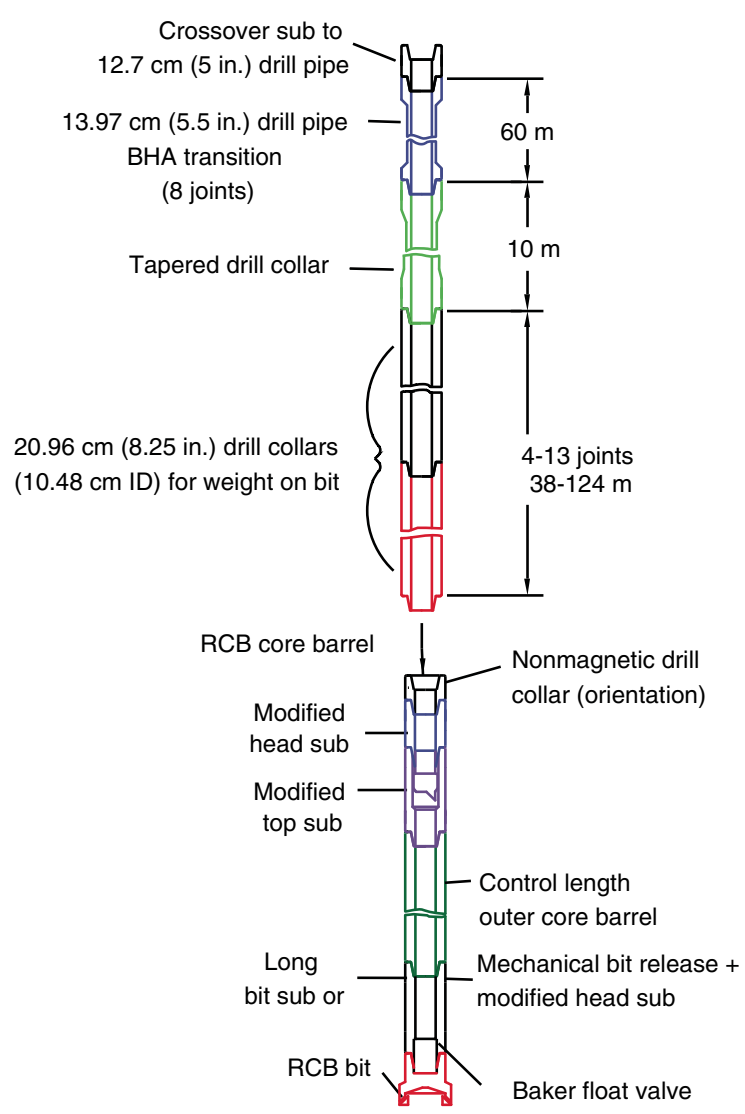

At 1000 h on 13 May 2018, we opened the moonpool and started lowering the $95.5 \mathrm{~m}$ long casing string and drilling assembly to the seafloor. Upon deploying the subsea camera system at $1530 \mathrm{~h}$, we spudded Hole U1527B at $1715 \mathrm{~h}$ at a water depth of $1464.2 \mathrm{~m}$. After drilling in the casing to $92 \mathrm{mbsf}$, drilling slowed to a stop with high standpipe pressures. We then worked the reentry system and eventually landed it on the seafloor, completing drilling in the casing when the bit reached $105.5 \mathrm{mbsf}$ at $0030 \mathrm{~h}$ on 15 May. The HRT was activated to release the drill string from the casing. After recovering the subsea camera system and pulling the drill string back to the ship, we found that the reentry system and casing were still attached to the drill string because the underreamer arms had not retracted. The reentry system was landed back in the moonpool, and the reentry funnel and hard rock landing frame were removed. After working the drill string, the underreamer was finally drawn up into the casing, and the HRT BHA was disassembled. When the end of the drill string cleared the rig floor at $1530 \mathrm{~h}$ on 15 May, we discovered that the 9.875 inch tricone bit was missing from the bit sub, which was damaged beyond repair (Table T1; Figure F6). After examining the damaged components and the rig instrumentation data, we determined that the bit most likely failed at $\sim 92 \mathrm{mbsf}$.

\section{Hole U1527C}

We offset the vessel $20 \mathrm{~m}$ south of Hole U1527B as we started making up a new reentry system for installation in Hole U1527C, utilizing the $95.5 \mathrm{~m}$ of casing already landed in the moonpool. A new 9.875 inch tricone bit and underreamer (set to 12.75 inches) were installed in the drilling assembly, which was shortened by $\sim 5$ $\mathrm{m}$. The remainder of the BHA, two stands of drill collars, and $23 \mathrm{~m}$ 
Table T1. Site U1527 core summary. DRF = drilling depth below rig floor, DSF = drilling depth below seafloor, RST = rotary shifting tool, N-Mag $=$ nonmagnetic core barrel, C-BIT = center bit. R = rotary core barrel, numeric core type $=$ drilled interval. Totals from Hole U1527C exclude drilled interval. (Continued on next page.) Download table in CSV format.

\section{Hole U1527A}

Latitude: $34^{\circ} 51.6528^{\prime} \mathrm{S}$

Longitude: $179^{\circ} 3.2397^{\prime} \mathrm{E}$

Seafloor (drill pipe measurement below rig floor, m DRF): 1475.0

Time on hole (days): 2.1

Total depth (drill pipe measurement from rig floor, $\mathrm{m}$ DRF): 1576.4

Distance between rig floor and sea level $(\mathrm{m}): 10.77$

Total penetration (drilling depth below seafloor, m DSF): 101.4

Total length of cored section (m): 101.4

Total core recovered $(\mathrm{m}): 1.27$

Core recovery (\%): 1.3

Drilled interval $(\mathrm{m}): 0$

Total cores (no.): 15

\section{Hole U1527C}

Latitude: $34^{\circ} 51.6625^{\prime} \mathrm{S}$

Longitude: $179^{\circ} 3.2534^{\prime} \mathrm{E}$

Seafloor (drill pipe measurement below rig floor, m DRF): 1475.0

Time on hole (days): 5.1

Total depth (drill pipe measurement from rig floor, $\mathrm{m} \mathrm{DRF):} 1713.0$

Distance between rig floor and sea level $(\mathrm{m}): 10.88$

Total penetration (drilling depth below seafloor, m DSF): 238.0

Total length of cored section $(\mathrm{m}): 138.1$

Total core recovered $(\mathrm{m}): 25.9$

Core recovery (\%): 18.8

Drilled interval (m): 99.9

Total cores (no.): 19

\section{Hole U1527B}

Latitude: $34^{\circ} 51.6519^{\prime} \mathrm{S}$

Longitude: $179^{\circ} 3.2526^{\prime} \mathrm{E}$

Seafloor (drill pipe measurement below rig floor, m DRF): 1475.0

Time on hole (days): 3.2

Total depth (drill pipe measurement from rig floor, m DRF): 1580.5

Distance between rig floor and sea level $(\mathrm{m}): 10.84$

Total penetration (drilling depth below seafloor, m DSF): 105.5

Total length of cored section $(\mathrm{m}): 0$

Total core recovered $(\mathrm{m}): 0$

Core recovery (\%): 0

Drilled interval $(\mathrm{m}): 105.5$

Total cores (no.): 0

\begin{tabular}{|c|c|c|c|c|c|c|c|c|c|c|c|c|}
\hline Core & $\begin{array}{l}\text { Top of } \\
\text { interval } \\
\text { DSF }(m)\end{array}$ & $\begin{array}{l}\text { Bottom of } \\
\text { interval } \\
\text { DSF }(m)\end{array}$ & $\begin{array}{l}\text { Interval } \\
\text { advanced } \\
\text { (m) }\end{array}$ & $\begin{array}{l}\text { Recovered } \\
\text { length } \\
(\mathrm{m})\end{array}$ & $\begin{array}{l}\text { Curated } \\
\text { length } \\
\text { (m) }\end{array}$ & $\begin{array}{l}\text { Recovery } \\
\text { (\%) }\end{array}$ & $\begin{array}{c}\text { Date on } \\
\text { deck } \\
(2018)\end{array}$ & $\begin{array}{l}\text { Time on } \\
\text { deck UTC } \\
\text { (h) }\end{array}$ & $\begin{array}{l}\text { Time to } \\
\text { cut core } \\
\text { (min) }\end{array}$ & $\begin{array}{l}\text { Core } \\
\text { barrel }\end{array}$ & $\begin{array}{l}\text { Mud } \\
\text { pumped } \\
\text { (bbl) }\end{array}$ & Driller's notes \\
\hline \multicolumn{13}{|c|}{ 376-U1527A- } \\
\hline $1 \mathrm{R}$ & 0.0 & 9.7 & 9.7 & & & & 10 May & 1150 & 25 & N-Mag & & Temperature strips. \\
\hline $2 \mathrm{R}$ & 9.7 & 19.4 & 9.7 & & & & 10 May & 1355 & 50 & N-Mag & & \\
\hline $3 R$ & 19.4 & 29.1 & 9.7 & & & & 10 May & 1540 & 30 & N-Mag & & Temperature strips. \\
\hline $4 \mathrm{R}$ & 29.1 & 38.8 & 9.7 & 0.00 & 0.01 & 0 & 10 May & 1735 & 35 & N-Mag & 30 & \\
\hline $5 \mathrm{R}$ & 38.8 & 48.5 & 9.7 & 0.34 & 0.37 & 4 & 10 May & 2040 & 55 & N-Mag & & Temperature strips; work out excess torque. \\
\hline $6 \mathrm{R}$ & 48.5 & 58.2 & 9.7 & 0.92 & 1.19 & 9 & 10 May & 2325 & 30 & N-Mag & 30 & Stuck at barrel landing; work out. \\
\hline $7 \mathrm{R}$ & 58.2 & 63.0 & 4.8 & & & & 11 May & 0033 & 20 & N-Mag & & Temperature strips. \\
\hline $8 \mathrm{R}$ & 63.0 & 67.8 & 4.8 & & & & 11 May & 0255 & 40 & N-Mag & 35 & $\begin{array}{l}\text { Work tight hole } 64-67 \text { mbsf. Max: } 800 \mathrm{~A}, \\
\text { overpull: } 60,000 \mathrm{lb} \text {. }\end{array}$ \\
\hline $9 \mathrm{R}$ & 67.8 & 72.6 & 4.8 & 0.01 & 0.01 & 0 & 11 May & 0525 & 20 & N-Mag & 30 & $\begin{array}{l}\text { Temperature strips, work tight hole } 67-73 \\
\text { mbsf. Max: } 800 \text { A, overpull: } 60,000 \mathrm{lb} .\end{array}$ \\
\hline $10 \mathrm{R}$ & 72.6 & 77.4 & 4.8 & & & & 11 May & 0815 & 20 & N-Mag & 30 & $\begin{array}{l}\text { Ran deplugger after Core 9R. Work tight hole } \\
77-72 \text { mbsf. Max: } 800 \mathrm{~A} \text {, overpull: } 40,000 \mathrm{lb} \text {. }\end{array}$ \\
\hline $11 \mathrm{R}$ & 77.4 & 82.2 & 4.8 & & & & 11 May & 0935 & 20 & N-Mag & & Temperature strips. \\
\hline $12 \mathrm{R}$ & 82.2 & 87.0 & 4.8 & & & & 11 May & 1115 & 10 & N-Mag & 30 & \\
\hline $13 \mathrm{R}$ & 87.0 & 91.8 & 4.8 & & & & 11 May & 1335 & 20 & N-Mag & 60 & $\begin{array}{l}\text { Temperature strips; work tight hole at } 1562 \mathrm{~m} \text {, } \\
\text { 88-91 mbsf. }\end{array}$ \\
\hline $14 \mathrm{R}$ & 91.8 & 96.6 & 4.8 & & & & 11 May & 1500 & 35 & N-Mag & & \\
\hline \multirow[t]{2}{*}{$15 \mathrm{R}$} & 96.6 & 101.4 & 4.8 & & & & 11 May & 1700 & 40 & N-Mag & 60 & No temperature strips. \\
\hline & \multicolumn{2}{|c|}{ Hole U1527A totals: } & 101.4 & 1.27 & 1.58 & 1.25 & & & & & & \\
\hline \multicolumn{13}{|c|}{ 376-U1527B- } \\
\hline 11 & 0.0 & 105.5 & $* * * * *$ Drill & lled from 0.0 & to $105.5 \mathrm{~m}$ & DSF $* * * * *$ & 14 May & 1232 & 1655 & C-BIT & 950 & Drill-in 10.75 inch casing. \\
\hline \multicolumn{13}{|c|}{ 376-U1527C- } \\
\hline 11 & 0.0 & 99.9 & \multicolumn{4}{|c|}{${ }^{* * * * *}$ Drilled from 0.0 to 99.9 m DSF***** } & 16 May & 1230 & 1225 & C-BIT & 240 & Drill-in 10.75 inch casing. \\
\hline $2 \mathrm{R}$ & 99.9 & 108.4 & 8.5 & & & 0 & 17 May & 1435 & 35 & N-Mag & 30 & \\
\hline $3 R$ & 108.4 & 118.0 & 9.6 & 0.05 & 0.05 & 1 & 17 May & 1655 & 110 & N-Mag & 40 & \\
\hline $4 \mathrm{R}$ & 118.0 & 127.6 & 9.6 & 0.01 & 0.01 & 0 & 17 May & 1825 & 135 & N-Mag & 30 & \\
\hline $5 \mathrm{R}$ & 127.6 & 137.2 & 9.6 & & & 0 & 17 May & 2000 & 240 & N-Mag & 30 & \\
\hline $6 \mathrm{R}$ & 137.2 & 146.8 & 9.6 & & & 0 & 17 May & 2125 & 230 & N-Mag & 30 & Unconsolidated tephra. \\
\hline $7 R$ & 146.8 & 156.4 & 9.6 & 0.08 & 0.09 & 1 & 17 May & 2250 & 170 & N-Mag & 30 & \\
\hline $8 \mathrm{R}$ & 156.4 & 166.0 & 9.6 & 0.08 & 0.13 & 1 & 18 May & 0000 & 200 & N-Mag & 30 & \\
\hline $9 \mathrm{R}$ & 166.0 & 175.6 & 9.6 & 0.03 & 0.05 & 0 & 18 May & 0215 & 135 & N-Mag & 60 & Note formation will not take weight on bit! \\
\hline $10 \mathrm{R}$ & 175.6 & 185.2 & 9.6 & 0.54 & 0.56 & 6 & 18 May & 0345 & 140 & N-Mag & 30 & Same as above. \\
\hline $11 \mathrm{R}$ & 185.2 & 194.8 & 9.6 & 2.77 & 3.12 & 29 & 18 May & 0615 & 120 & N-Mag & 30 & Formation change at $\sim 187$ mbsf. \\
\hline $12 \mathrm{R}$ & 194.8 & 199.6 & 4.8 & 2.72 & 2.82 & 57 & 18 May & 0745 & 165 & N-Mag & 30 & \\
\hline $13 \mathrm{R}$ & 199.6 & 204.4 & 4.8 & 4.22 & 4.23 & 88 & 18 May & 0910 & 175 & N-Mag & 30 & \\
\hline $14 \mathrm{R}$ & 204.4 & 209.2 & 4.8 & 3.57 & 3.66 & 74 & 18 May & 1050 & 190 & N-Mag & 60 & \\
\hline $15 \mathrm{R}$ & 209.2 & 214.0 & 4.8 & 3.30 & 3.55 & 69 & 18 May & 1230 & 125 & N-Mag & 30 & \\
\hline
\end{tabular}


Table T1 (continued).

\begin{tabular}{|c|c|c|c|c|c|c|c|c|c|c|c|c|}
\hline Core & $\begin{array}{l}\text { Top of } \\
\text { interval } \\
\text { DSF }(m)\end{array}$ & $\begin{array}{c}\text { Bottom of } \\
\text { interval } \\
\text { DSF }(m)\end{array}$ & $\begin{array}{l}\text { Interval } \\
\text { advanced } \\
\text { (m) }\end{array}$ & $\begin{array}{l}\text { Recovered } \\
\text { length } \\
(\mathrm{m})\end{array}$ & $\begin{array}{l}\text { Curated } \\
\text { length } \\
\text { (m) }\end{array}$ & $\begin{array}{c}\text { Recovery } \\
\text { (\%) }\end{array}$ & $\begin{array}{c}\text { Date on } \\
\text { deck } \\
(2018)\end{array}$ & $\begin{array}{l}\text { Time on } \\
\text { deck UTC } \\
\text { (h) }\end{array}$ & $\begin{array}{l}\text { Time to } \\
\text { cut core } \\
\text { (min) }\end{array}$ & $\begin{array}{l}\text { Core } \\
\text { barrel }\end{array}$ & $\begin{array}{l}\text { Mud } \\
\text { pumped } \\
\text { (bbl) }\end{array}$ & Driller's notes \\
\hline $16 \mathrm{R}$ & 214.0 & 218.8 & 4.8 & 1.5 & 1.50 & 31 & 18 May & 1400 & 145 & N-Mag & 30 & \\
\hline $17 R$ & 218.8 & 223.6 & 4.8 & 2.03 & 2.47 & 42 & 18 May & 1525 & 135 & N-Mag & 30 & \\
\hline $18 \mathrm{R}$ & 223.6 & 228.4 & 4.8 & 2.82 & 2.89 & 59 & 18 May & 1700 & 115 & N-Mag & 30 & \\
\hline $19 R$ & 228.4 & 233.2 & 4.8 & 1.35 & 1.80 & 28 & 18 May & 1820 & 125 & N-Mag & 30 & \\
\hline \multirow[t]{2}{*}{$20 \mathrm{R}$} & 233.2 & 238.0 & 4.8 & 0.83 & 1.18 & 17 & 19 May & 0915 & 145 & N-Mag & 90 & Tight hole at $1709 \mathrm{~m} ; 2$ wireline runs for RST. \\
\hline & Hole U1 & $527 C$ totals: & 238.0 & 25.90 & 28.10 & 18.8 & & & & & & \\
\hline
\end{tabular}

Figure F5. Underreamer tool. Roller cone cutters made up of tungsten carbide were used during Expedition 376. After Graber et al. (2002).

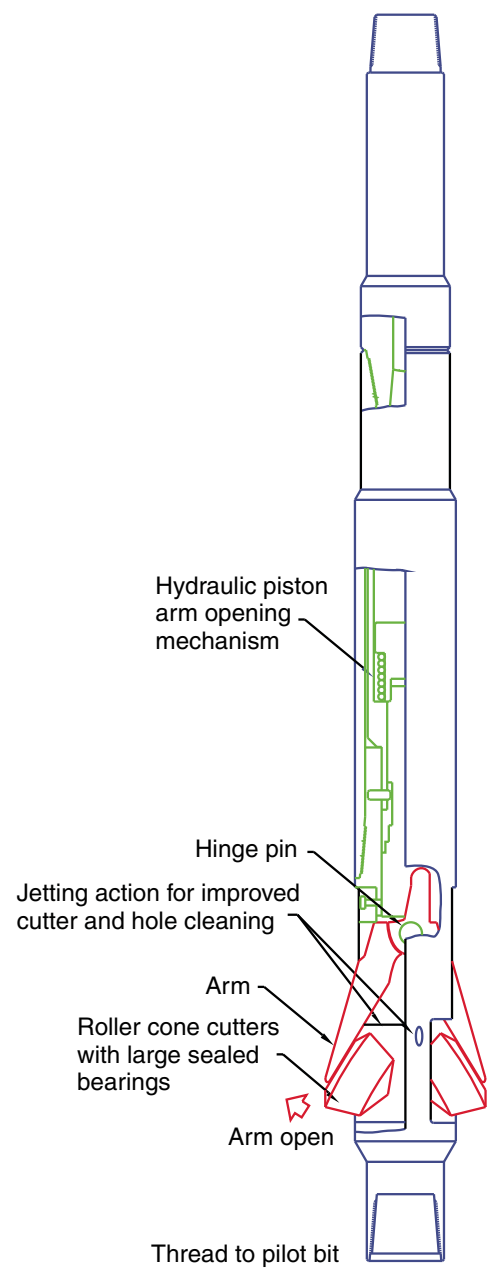

of drill pipe were assembled, and the HRT stand was attached to the top of the casing string. The drilling assembly was lowered through the moonpool and bolted to the casing string. The reentry funnel was then reassembled in the moonpool. The assembled reentry funnel and the hard rock landing frame were welded to the casing.

At $0615 \mathrm{~h}$ on 16 May 2018, the reentry system and $95.5 \mathrm{~m}$ long casing string (Figure F7) were lowered through the open moonpool doors to the seafloor. The subsea camera system was deployed at $0945 \mathrm{~h}$ to observe the reentry funnel while drilling in the casing. Hole U1527C was spudded at $1130 \mathrm{~h}$ on 16 May. Drilling was completed at $0045 \mathrm{~h}$ on 17 May when the bit reached 99.9 mbsf. The HRT was activated through deployment of a go-devil tool, which
Figure F6. Damaged bit sub recovered from the end of the drill string pulled out of Hole U1527B. Bit sub was damaged beyond repair by wearing during drilling in casing after the pilot bit had failed. (Credit: Tobias W. Höfig, IODP JRSO)

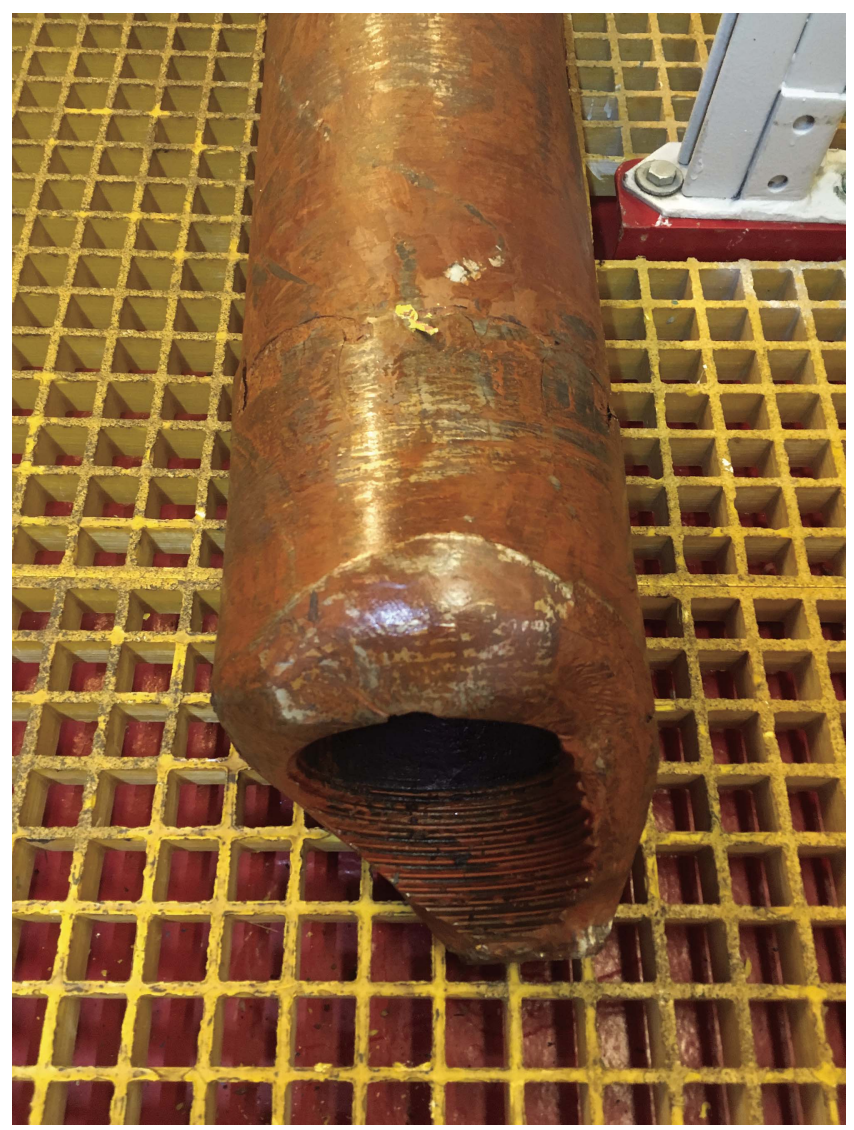

freed the drill string from the casing. The drill string was raised so that the HRT was visible above the reentry funnel. After the underreamer was verified to have entered the casing, the remainder of the hole was displaced with heavy mud. The drill string was pulled out of the hole, and the bit reached the rig floor at $1150 \mathrm{~h}$ on 17 May. The BHA was disassembled, and the mud motor and underreamer were flushed with freshwater.

An RCB BHA was made up, including a new RCB bit, and at $1300 \mathrm{~h}$ the drill string was lowered to the seafloor. We deployed the subsea camera system, located the reentry funnel immediately, and reentered Hole U1527C at 2014 h on 17 May after only 14 min of maneuvering. Upon recovery of the subsea camera system, the bit was washed down (i.e., drilled without coring) to $99.9 \mathrm{mbsf}$, and 30 bbl of mud sweep were pumped. We dropped a core barrel and be- 
Figure F7. Hole U1527C reentry system and casing installation, depicting the different operation steps, formation conditions, and associated depths (not to $\mathrm{scale}$ ). $\mathrm{mbsf}=$ meters below seafloor, $\mathrm{mbsl}=$ meters below sea level.

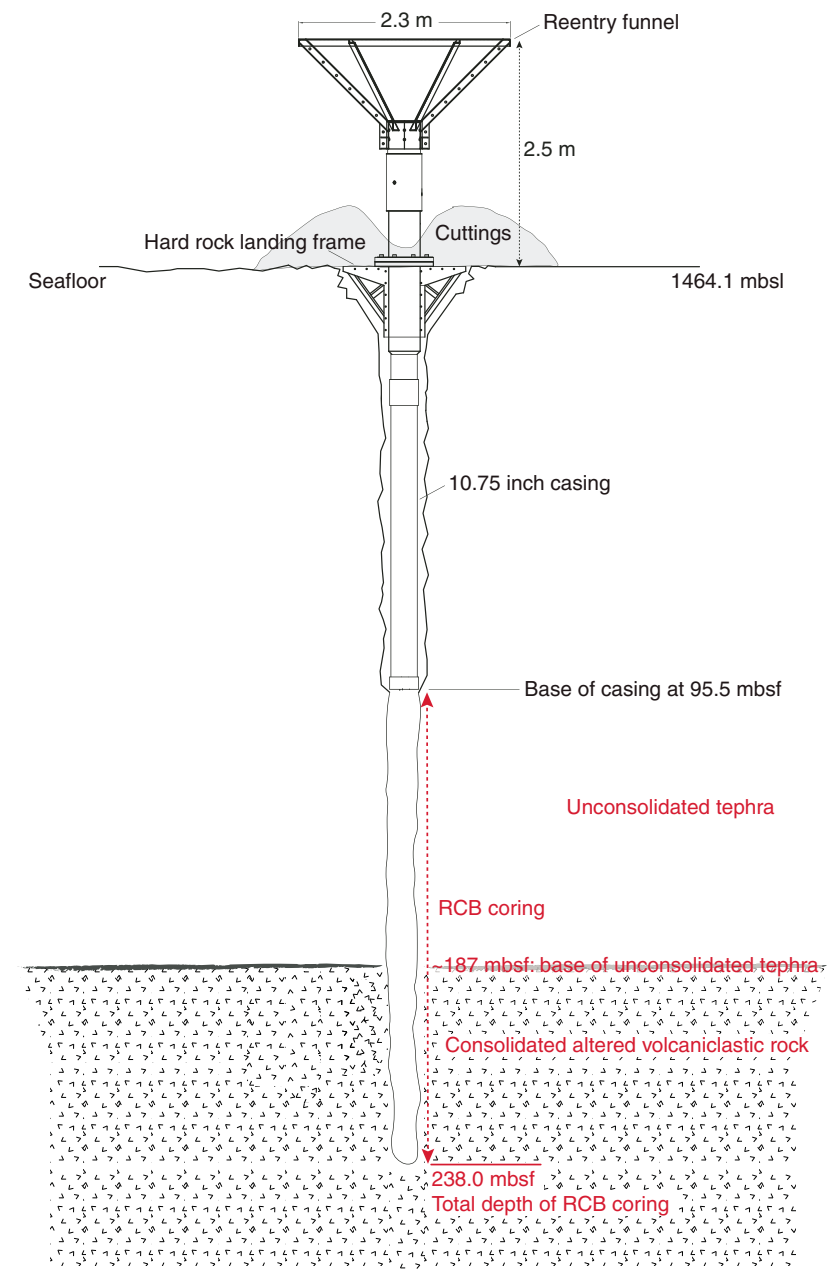

gan RCB coring from 99.9 mbsf. Cores 376-U1527C-2R through 20R penetrated to $238.0 \mathrm{mbsf}$ and recovered $25.9 \mathrm{~m}$ of core $(19 \%)$. The first nine of these cores took only 10 min each to cut but had no to poor recovery ( 0 to $0.54 \mathrm{~m}$ ); they retrieved pebbles from unconsolidated volcanic deposits. While cutting Core 11R, we encountered a substantial formation change at $\sim 187 \mathrm{mbsf}$ and core recovery improved to $29 \%$. The improvement in recovery was coincident with the intersection of consolidated volcaniclastic rock. After Core $11 \mathrm{R}$, we switched to half-length advances $(4.8 \mathrm{~m})$ and continued through Core 20R, recovering $54 \%$ on average. All cores, penetration depths, core recovery, and times recovered on deck are shown in Table T1. Regular mud sweeps were required to keep the hole clean, and $425 \mathrm{bbl}$ of high-viscosity mud were pumped during the coring.

While pulling up to make a connection after cutting Core 376U1527C-20R at $0700 \mathrm{~h}$ on 19 May, we experienced high torque with the bit at 234 mbsf. Although circulation and rotation were maintained, we had problems picking up the drill string. After working the stuck pipe for $13.75 \mathrm{~h}$, we were unable to work it past $125 \mathrm{mbsf}$ ( $30 \mathrm{~m}$ below the end of the casing string). The decision was made to release the bit in the hope that we would be able to pull the drill string clear of the hole. We offset the vessel $\sim 75 \mathrm{~m}$ to access a drill pipe connection at the rig floor to retrieve Core 20R and to release the bit in an attempt to free the drill string. The vessel was offset back to its original location while tension was maintained on the drill string, and attempts to free the stuck pipe continued. Eventually, the drill string cleared the seafloor at $0155 \mathrm{~h}$ on 20 May, but an overpull was observed at $0530 \mathrm{~h}$. The reentry system was still attached to the drill string. The reentry system was later secured in the moonpool, and the hard rock landing frame was removed from the system. Upon removal of the reentry funnel, we broke the flange connection and cleaned out cuttings made up of lapilli-sized tephra that clogged the HRT latch sleeve and upper casing sub. The cuttings were collected and curated for sampling. After working the drill string up and down, it was freed from the reentry system and pulled back to the rig floor. The bit cleared the rig floor at $1725 \mathrm{~h}$ on 20 May, ending Hole U1527C. While disassembling the remainder of the reentry system, including eight joints of 10.75 inch casing, the vessel moved to Site U1528 about $1 \mathrm{nmi}$ away using the dynamic positioning system.

\section{Igneous petrology and volcanology}

At Site U1527, two igneous units were recovered (Figure F8). Igneous Unit 1 consists of dacite lava and subordinate polymict lapilli tephra (see Table T2 in the Expedition 376 methods chapter [de Ronde et al., 2019a]). Dacite lava was recovered in Hole U1527A between intervals $5 \mathrm{R}-1,0 \mathrm{~cm}$, and 6R-1, $114 \mathrm{~cm}$ (38.80-49.64 mbsf), and in Hole U1527C in Cores 3R-10R (108.40-176.16 mbsf) (Figure F8). Polymict lapilli tephra containing both scoria and pumice clasts were present in intervals 376-U1527A-4R-CC, $0-1 \mathrm{~cm}$ (29.10-29.11 mbsf), 6R-1, 115-118 cm (49.64-49.69 mbsf), and 9RCC, 0-1 cm (67.80-67.81 mbsf). Furthermore, scoria lapilli were recovered from the BHA in Hole U1527C. These lapilli are grouped with Igneous Unit 1 because the scoria clasts are likely to be stratigraphically related to the unaltered, more massive dacite lava.

Igneous Unit 2 consists of hydrothermally altered lapilli-tuff, lapillistone, and tuff-breccia and was recovered in Hole U1527C from Cores 11R-20R (185.20-234.38 mbsf). It is divided into four subunits $(2 \mathrm{a}-2 \mathrm{~d})$ based on changes in the type of alteration, matrixto-clast ratio, and color (Figure F8). Igneous Subunit 2a is monomict lapilli-tuff consisting of unaltered dacitic fragments surrounded by a brown, fine-grained matrix. Subunit $2 b$ is composed of pervasively altered, matrix-supported, poorly sorted monomict and polymict lapilli-tuff, lapillistone, and tuff-breccia, as well as subordinate tuff and pyroclastic breccia. Subunit 2c consists of clast-supported, poorly sorted, polymict lapillistone, whereas Subunit $2 \mathrm{~d}$ is made up of altered matrix- and clast-supported polymict lapilli-tuffs and clast-supported monomict tuff-breccia. The degree of hydrothermal alteration increases downhole with an increase in silicification and greater abundance of secondary sulfides (see Alteration). The contact between Units 1 and 2 was not recovered.

\section{Igneous Unit 1}

Intervals: 376-U1527A-4R-CC, $0 \mathrm{~cm}$, to 9R-CC, $1 \mathrm{~cm}$; 376U1527C-3R-1, $0 \mathrm{~cm}$, to $10 \mathrm{R}-1,56 \mathrm{~cm}$

Depths: Hole U1527A $=29.10-67.81$ mbsf; Hole U1527C = 108.40-176.16 mbsf

Lithology: unaltered plagioclase-phyric dacite lava and polymict tephra

Igneous Unit 1 is unaltered plagioclase-phyric dacite lava that likely represents lava flows intercalated with lapilli block/bombsized tephra. Because of core diameter restrictions, the distinction 
Figure F8. Lithostratigraphic summary, Holes U1527A and U1527C.
U1527A

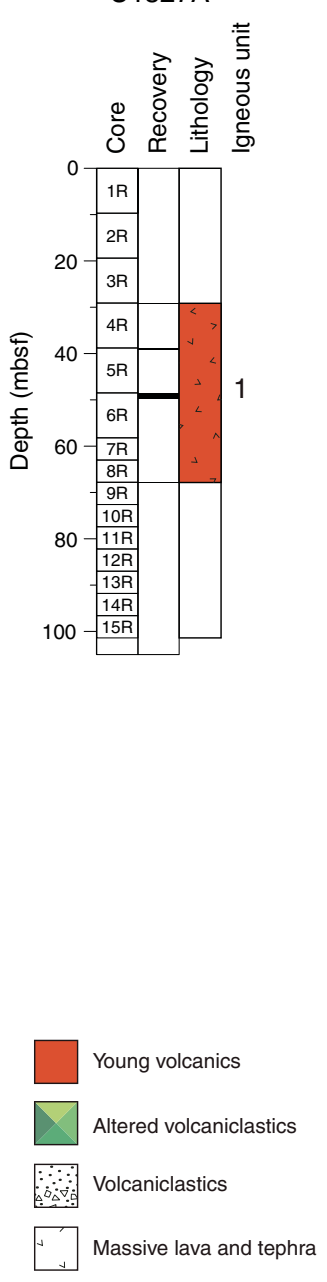

U1527C

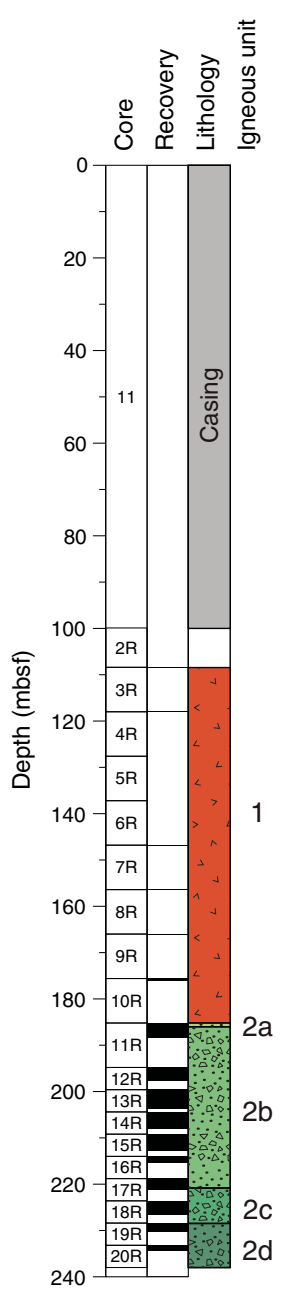

between lava flow and tephra is not easy to discern. The black, porphyritic, and glomeroporphyritic fine-grained lava (flow or block/bomb-sized tephra) is moderately to highly vesicular and contains rare plagioclase phenocrysts as large as $2 \mathrm{~mm}$ (Figure F9). Thin section observations indicate a primary mineral assemblage of plagioclase and clinopyroxene phenocrysts \pm magnetite set in a groundmass of unaltered to slightly altered glass. The phenocrysts have an equigranular texture with scattered tabular plagioclase $(<1$ $\mathrm{mm})$ and blocky clinopyroxene $(<1 \mathrm{~mm})$ crystals, as well as glomeroporphyritic clots of plagioclase (as large as $3 \mathrm{~mm}$ ), clinopyroxene (as large as $3 \mathrm{~mm}$ ), and magnetite (as large as $0.4 \mathrm{~mm}$ ) that make up approximately $2-3 \mathrm{vol} \%$ of the rock. Plagioclase crystals in Unit 1 show rare oscillatory zonation. The groundmass consists of 30-50 vol\% unaltered to slightly altered dark brown glass with an intersertal texture of randomly oriented acicular to swallow-tail plagioclase crystals. These crystals are $<0.1 \mathrm{~mm}$ long and make up $\sim 15$ vol\% of the rock. Vesicles range in size from 0.2 to $5 \mathrm{~mm}$, are subrounded to angular, and exhibit low (irregular) to moderate sphericity (see Figure F12 in the Expedition 376 methods chapter [de Ronde et al., 2019a]). Their volume ranges from 40 to $50 \mathrm{vol} \%$ of the rock (Figure F10). The dacitic composition was first confirmed by portable X-ray fluorescence (pXRF) measurements (see Geochemistry) and found to be very similar in composition to the silica-poor
Figure F9. Representative macroscopic samples from Igneous Unit 1, Holes U1527A and U1527C. A. Plagioclase phyric dacite lava. B. Plagioclase-pyroxene phyric dacite lava with elongate vesicles. C. Polymict lapilli tephra containing pumice mixed with scoria. D. Sample recovered from unconsolidated material that obstructed the BHA.
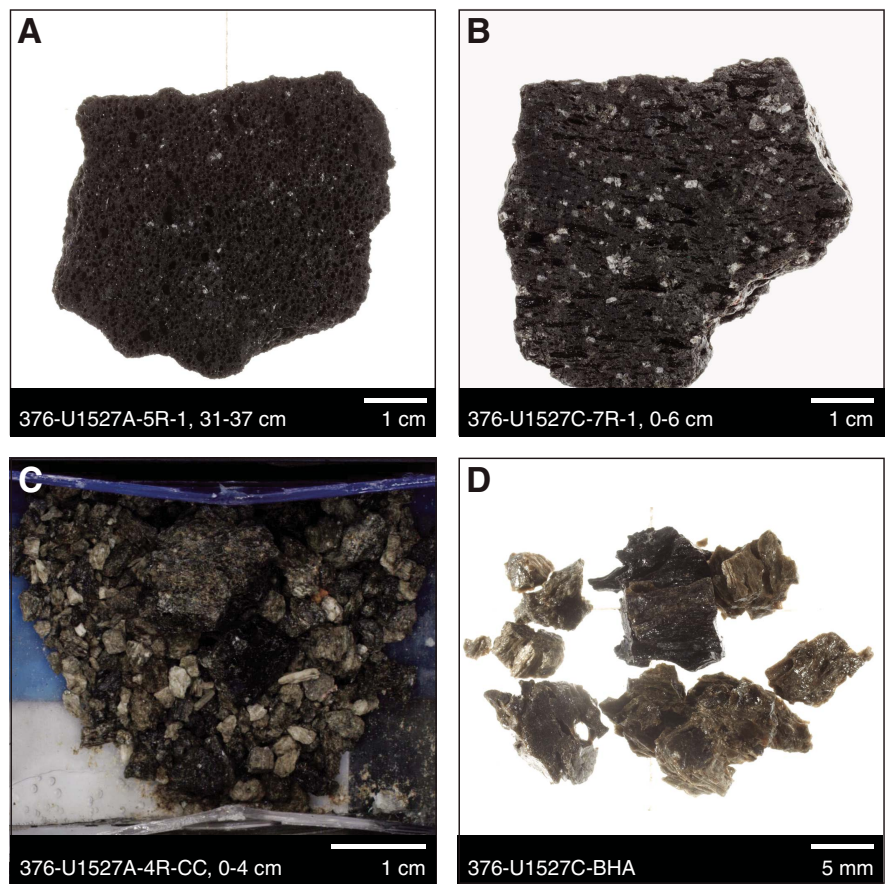

dacites previously reported from Brothers volcano (e.g., Wright and Gamble, 1999; Haase et al., 2006; Timm et al., 2012).

The volcaniclastic material recovered from Hole U1527A consists of fine- to medium-grained lapilli that are poorly to moderately sorted and composed of angular scoria and pumice clasts (Figures F9, F11). The stratigraphic and depositional context of the lapilli is unknown because it was lost, presumably by drilling. The black scoria is mostly fresh, contains sparse spherical vesicles, and appears similar to the dacitic lava. Pumice clasts from Sections 376-U1527A4R-CC and 9R-CC are white-gray in color and highly vesicular, whereas the pumiceous texture of green-gray colored clasts from Section 6R-1 is evident only under the scanning electron microscope (Figure F11). Section 4R-CC is host to a medium-sized scoria lapillus (see Table T2 in the Expedition 376 methods chapter [de Ronde et al., 2019a]) mixed with a pumiceous-looking clast. Material recovered after cleaning the Hole U1527C BHA consists almost exclusively of ash- to medium lapilli-sized scoria. Most clasts are black, glassy, and moderately vesicular and sometimes show fluidal textures. Many of the more fine grained clasts are brown, appear shiny, and are highly vesicular. However, they do not seem to constitute a different component because some larger clasts show a transition from a black glassy texture to a brown vesicular appearance (Figure F9D). All volcaniclastic samples contain very minor amounts of lithic components (fine-grained, unknown lithology) and no crystals.

\section{Igneous Unit 2}

Interval: 376-U1527C-11R-1, $0 \mathrm{~cm}$, to $20 \mathrm{R}-1,114 \mathrm{~cm}$ Depth: $185.20-234.38$ mbsf

Lithology: altered lapilli-tuff, lapillistone, and tuff-breccia; subordinate altered tuff and pyroclastic breccia 
Figure F10. Representative photomicrographs of Igneous Unit 1, Hole U1527A. A. Plagioclase phyric dacite lava containing subrounded vesicles (V) in groundmass containing altered glass (plane-polarized light [PPL]). B. Euhedral plagioclase (Plag) phenocrysts surrounded by plagioclase microlites (cross-polarized light [XPL]). C. Glomerocryst containing plagioclase and clinopyroxene (Cpx) (XPL). D. Subrounded vesicles in groundmass containing altered glass (PPL). E. Euhedral plagioclase and clinopyroxene phenocrysts surrounded by plagioclase microlites and vesicles (XPL). F. Glomerocryst containing plagioclase and clinopyroxene (XPL).
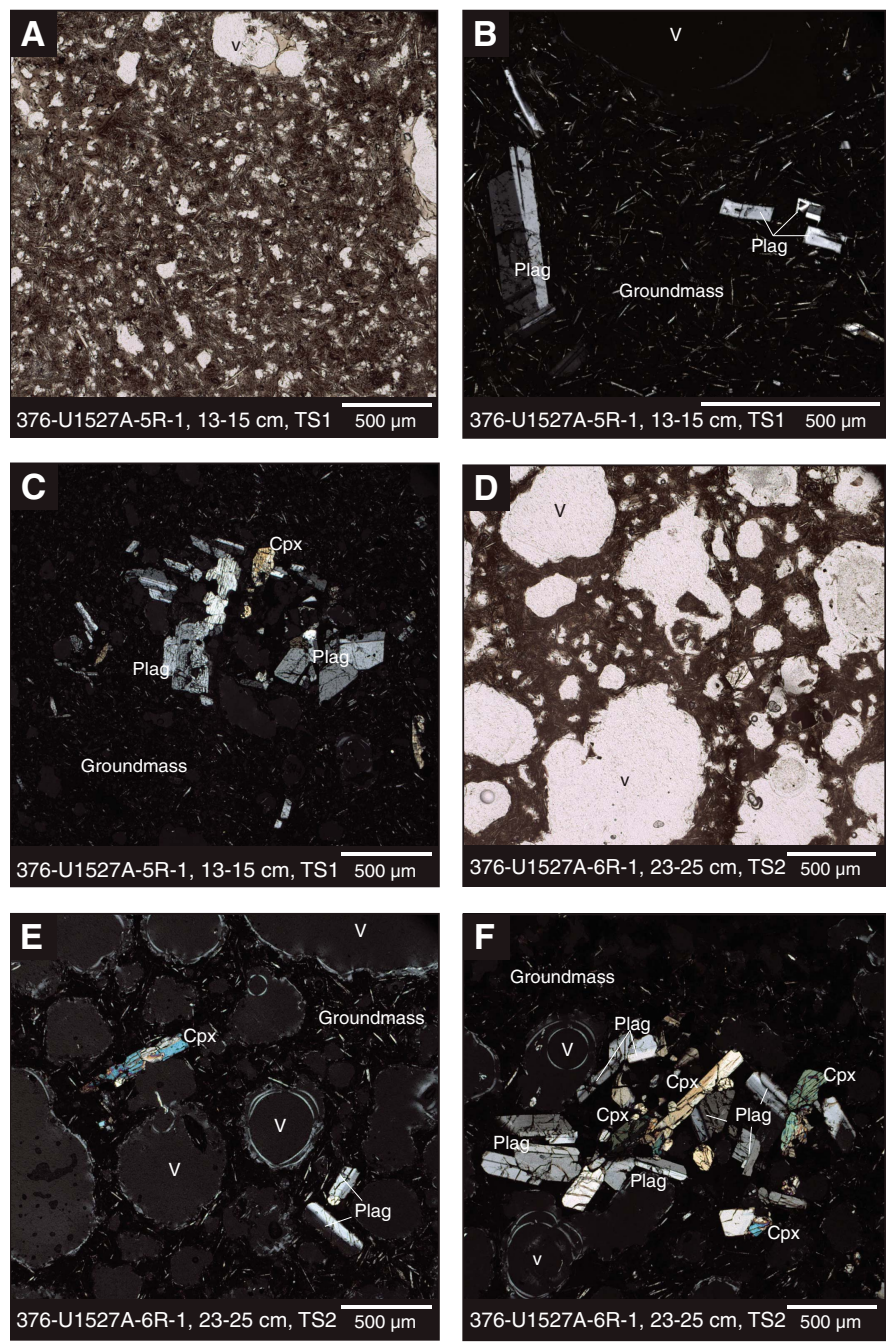

\section{Igneous Subunit 2a}

Interval: 376-U1527C-11R-1, $0 \mathrm{~cm}$, to $11 \mathrm{R}-1,24 \mathrm{~cm}$

Depth: 185.20-185.44 mbsf

Lithology: matrix-supported, monomict lapilli-tuff

Igneous Subunit 2a consists of matrix-supported, monomict lapilli-tuff. Slightly altered medium to coarse lapilli-sized clasts of dacite lava similar to that in Igneous Unit 1 are embedded in a brown, fine-grained, cemented matrix that probably represents altered (oxidized) tuff (Figures F12, F13). Thin section observations of the clasts confirm that the primary mineral assemblage is very similar to that of the unaltered dacite lava (i.e., plagioclase, clinopyroxene, magnetite, and a trachytic groundmass) (Figure F13). The dacite clasts have scattered tabular plagioclase $(<1 \mathrm{~mm})$ and blocky clinopyroxene $(<0.5 \mathrm{~mm})$ crystals, as well as glomeroporphyritic
Figure F11. Representative pumice and scoria clasts imaged using the shipboard scanning electron microscope, Holes U1527A and U1527C.
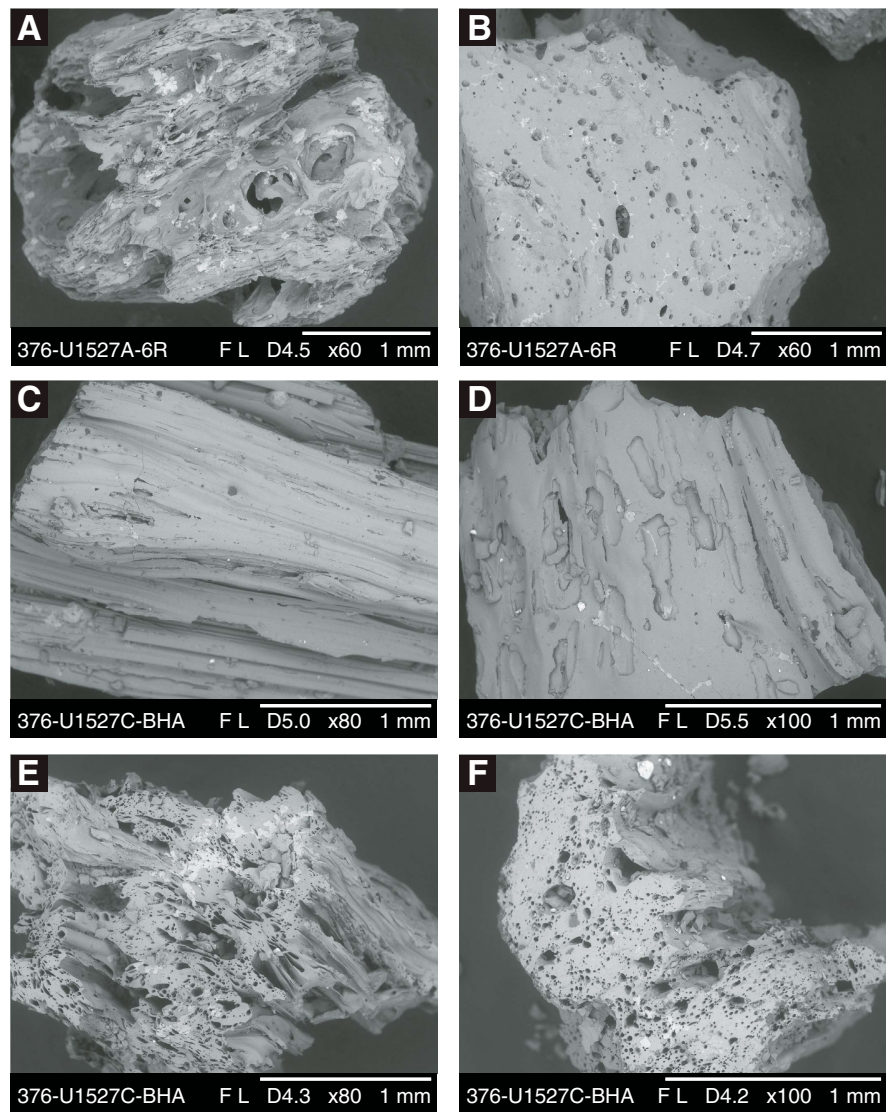

clots of plagioclase (as large as $1 \mathrm{~mm}$ ), clinopyroxene (as large as 0.6 $\mathrm{mm}$ ), and sparse magnetite (as large as $0.1 \mathrm{~mm}$ ), all of which make up approximately $15 \mathrm{vol} \%$ of the clasts. Plagioclase in Subunit 2a shows lamellar twinning and zoning. The groundmass of the clasts consists of $\sim 45 \mathrm{vol} \%$ partially altered, dark brown glass with both a trachytic texture of oriented acicular plagioclase microlites and a perlitic texture due to hydration of the glass. Vesicles make up $\sim 40$ vol\% of the clasts and range in size from 0.2 to $5 \mathrm{~mm}$, are subrounded to angular, and exhibit low (irregular) to moderate sphericity. The moderately altered, brownish matrix of the sample contains scattered, fractured crystals of subhedral to euhedral plagioclase (Figure F14) and clinopyroxene $(\sim 0.5 \mathrm{~mm})$ and some randomly oriented plagioclase microlites.

\section{Igneous Subunit 2b}

Interval: 376-U1527C-11R-1, $24 \mathrm{~cm}$, to $17 \mathrm{R}-2,83 \mathrm{~cm}$ Depth: 185.44-220.98 mbsf

Lithology: altered matrix-supported, monomict and polymict lapilli-tuff, lapillistone, and tuff-breccia; subordinate altered tuff with lapilli; and altered matrix-supported, monomict pyroclastic breccia with lapilli

Igneous Subunit $2 \mathrm{~b}$ mostly consists of matrix-supported, poorly sorted, monomict and polymict lapilli-tuff, lapillistone, and tuffbreccia, as well as subordinate tuff with lapilli and matrix-supported, monomict pyroclastic breccia with lapilli. The subunit is pervasively altered (see Alteration) with dominant greenish gray coloring, but it also displays very dark gray, bluish gray, brownish 
Figure F12. Representative macroscopic samples from Igneous Unit 2, Hole U1527C. A. Subunit 2a. B. Subunit 2b. C. Subunit 2c. D. Subunit 2d.
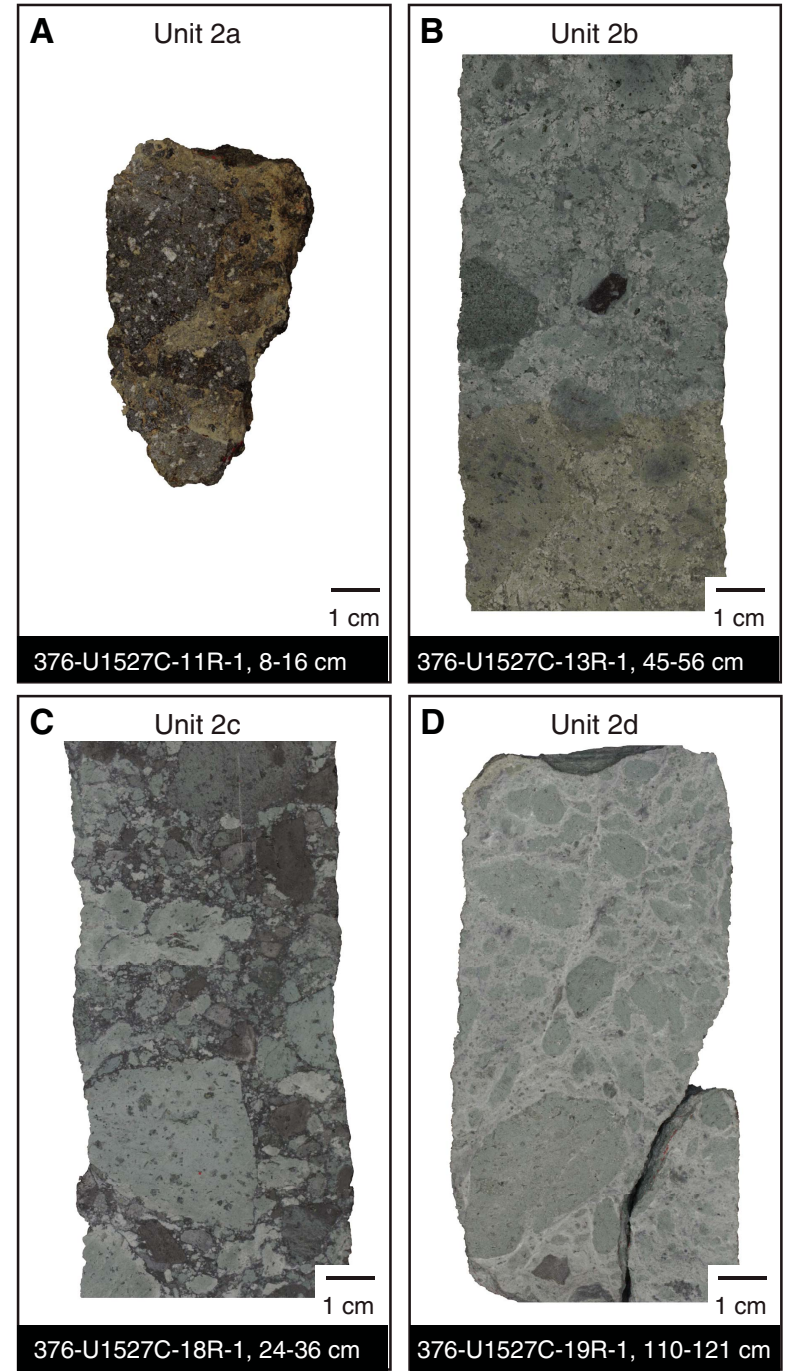

gray, olive, and (light) olive-gray colors. The matrix is fine grained, cemented, and probably represents completely altered tuff. Grain sizes of clasts range from granules to cobbles (see Table T2 in the Expedition 376 methods chapter [de Ronde et al., 2019a]). Boundaries of individual clasts are often no longer clearly distinguishable, making it difficult to determine the degree of roundness. However, larger clasts generally appear mostly subangular, whereas smaller ones (fine and medium lapilli) are more commonly subrounded. Macroscopically, the clasts appear to have the same volcanic textures and mineralogical content as the unaltered lava (Figure F12). Three different types of clasts could be distinguished macroscopically, and they are listed in order of their relative abundance (high to low):

- Clast Type 2b-1: altered volcanic clasts with light green or greenish gray colors (Figure F15A-F15C) represent the most dominant clast type. The larger clasts display original volcanic features such as vesicles and phenocrysts. Vesicles are usually filled by secondary minerals and are often elongated and aligned, producing an almost fiamme-like shape. Some clasts contain black, fluidal structures (see Alteration). Microscopi-
Figure F13. Thin section of Subunit 2a, Hole U1527C. A. PPL. B. XPL. Phenocrysts of plagioclase (Plag) and clinopyroxene (Cpx) are shown. In both images, the stippled yellow lines mark the boundaries between clasts and matrix.
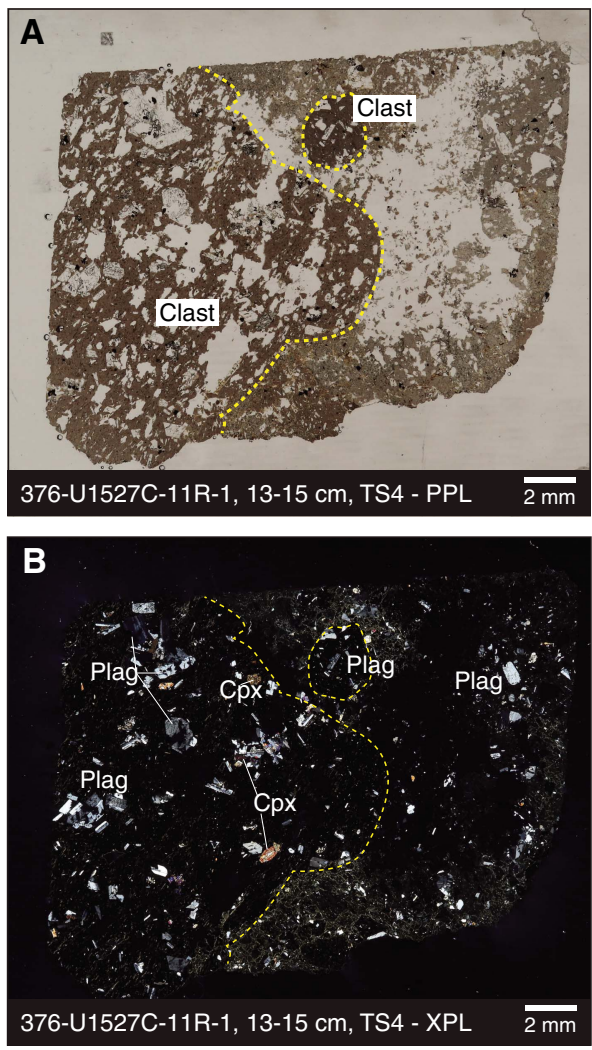

cally, the original groundmass (plagioclase microlites and glass) is largely preserved in the clasts in the upper parts of Subunit 2b; however, it becomes increasingly replaced by quartz, chlorite, clay, and accessory disseminated fine-grained $(0.05 \mathrm{~mm})$ euhedral pyrite with depth (see Alteration). The clasts are composed of $15-20 \mathrm{vol} \%$ plagioclase as both glomerocrysts (as large as 4 $\mathrm{mm}$ ) and phenocrysts (average size $=1 \mathrm{~mm}$ ), $\sim 1$ vol\% clinopyroxene (average size $=0.4 \mathrm{~mm}$ ), and accessory anhedral magnetite (average size $=0.1 \mathrm{~mm}$ ).

- Clast Type 2b-2: fine-grained, darker green clasts (Figure F15D-F15F). Because of their fine-grained/microcrystalline structure, the original lithology is mostly unidentifiable without the aid of thin sections, but some green clasts were macroscopically identified as altered tuff. Sometimes these clasts exhibit foliation. Furthermore, they are occasionally found enclosed within Type $2 \mathrm{~b}-1$ clasts. Type $2 \mathrm{~b}-2$ clasts contain plagioclaseclinopyroxene glomerocrysts and plagioclase phenocrysts in a groundmass of altered volcanic glass hosting plagioclase microlites. Glomerocrystic clots constitute $\sim 5 \mathrm{vol} \%$ of the clasts and are composed of plagioclase $(\sim 1 \mathrm{~mm})$ and anhedral clinopyroxene $(\sim 0.2 \mathrm{~mm})$. Plagioclase phenocrysts (average size is 0.2 $\mathrm{mm}$ ) constitute $2 \mathrm{vol} \%$ of the clasts. The groundmass is altered to quartz and chlorite with traces of anhedral pyrite (0.2 vol\%).

- Clast Type 2b-3: dark gray volcanic clasts (Figure F15G-F15I). Macroscopically, these clasts appear less altered than the other two clast types. Microscopically, however, they are the most altered of the three types, and the style of alteration affects all components of the clast except the plagioclase feldspars. These 
Figure F14. Representative microscopic textures from Igneous Unit 2, Hole U1527C. A. Plagioclase (Plag) phenocryst with a resorbed core and oscillatory zoned rim in Subunit $2 \mathrm{~b}(\mathrm{XPL})$. B. Clinopyroxene (Cpx) and magnetite $(\mathrm{Mt})$ phenocrysts with plagioclase microlites preserved in the matrix of Subunit 2a (XPL). C. Plagioclase phenocrysts in a groundmass with perlitic fracturing, outlined in yellow stippled lines, Subunit $2 b(P P L)$. D. Fractured plagioclase phyric clast, Subunit 2a (PPL). E. Quartz (Qtz) pseudomorph after glomeroporphyritic clinopyroxene in a groundmass containing plagioclase microlites, Subunit $2 b$ (XPL). F. Plagioclase phenocryst in a quartz-rich matrix, Subunit $2 b(X P L)$.
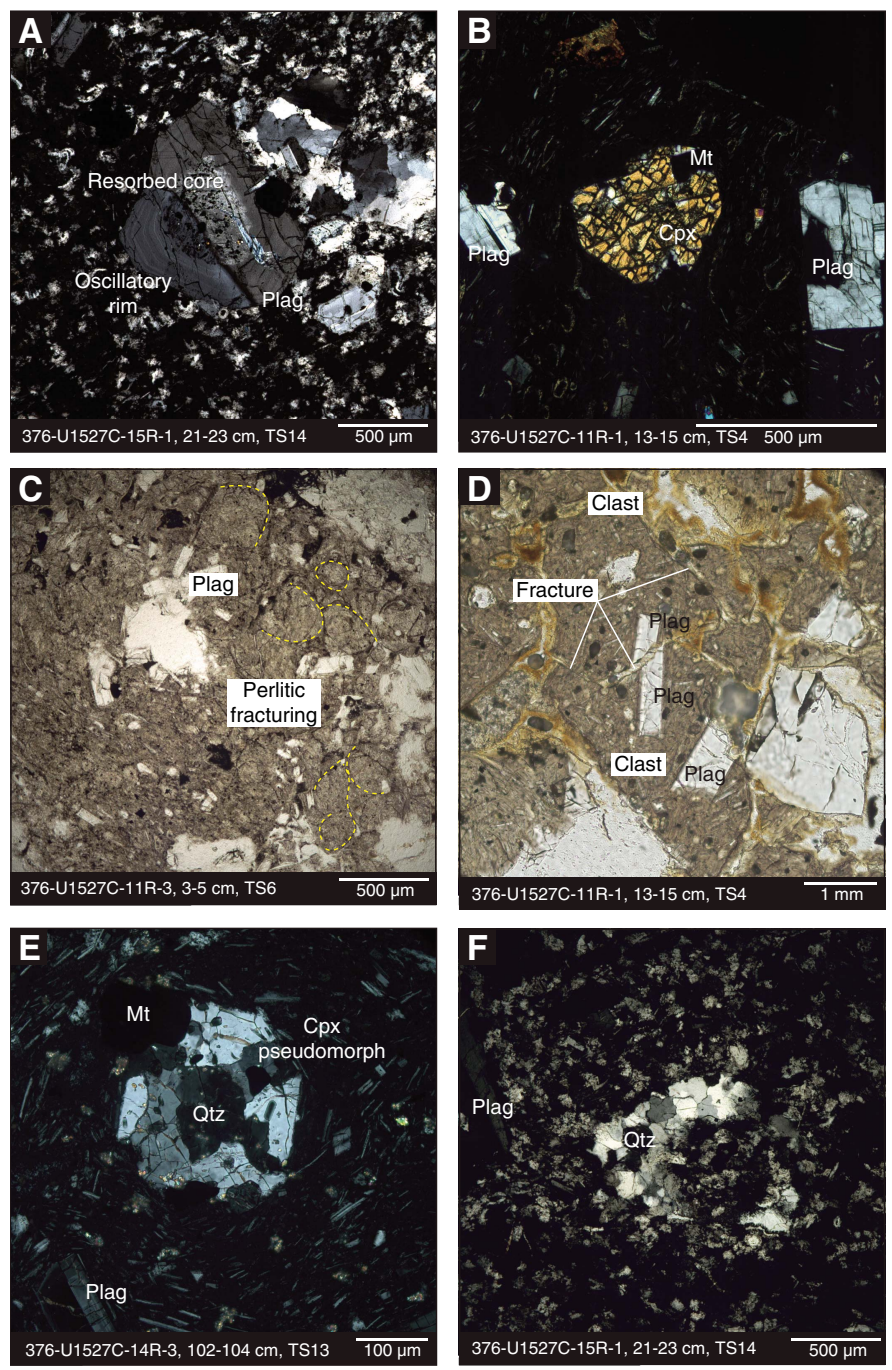

clasts have low vesicularity, are usually subangular, and are also commonly found enclosed within Type $2 \mathrm{~b}-1$ clasts. The mineral assemblage in these clasts consists of phenocrysts $(\sim 0.1 \mathrm{~mm})$ and glomerocrysts $(\sim 2 \mathrm{~mm})$ of $\sim 40-50 \mathrm{vol} \%$ plagioclase, $\sim 10$ vol\% clinopyroxene $(0.2 \mathrm{~mm})$, and $1-5 \mathrm{vol} \%$ magnetite $(0.1 \mathrm{~mm})$ emplaced in a groundmass of altered glass. Plagioclase phenocrysts are relatively unaltered; however, clinopyroxene crystals are mostly or entirely altered and, in some cases, replaced by quartz. Plagioclase microlites in the groundmass show trachytic flow textures. Minor chlorite overprints as much as $20 \mathrm{vol} \%$ of the groundmass.

Oscillatory zoning and lamellar twinning in plagioclase and in situ fracturing of individual crystals were observed in all three types of clasts and in the matrix of Subunit 2b (Figure F14). Plagioclase crystals with a resorbed core hosting melt and mineral inclusions were observed locally. All three clasts appear to have the same protolith (i.e., a glassy and occasionally vesicular glomeroporphyritic dacite with a trachytic groundmass that has undergone variable degrees of alteration). From the top of Hole U1527C to the bottom, pyroxene abundance decreases, and replacement by secondary quartz is more frequently observed downhole (Figure F14). Vesicularity of clasts varies from nonvesicular to a maximum of $40 \%$ vesicles. With depth, vesicles become infilled with secondary quartz. Although Type 2b-1 clasts were recognizable throughout Unit 2, the other two clast types were less common and were not observed in all of the subunits.

The matrix surrounding these three clast types appears similar to the groundmass of the dacitic lava, with a trachytic texture and microcrystalline plagioclase. Thus, distinguishing clasts from matrix is challenging. In the upper part of Subunit $2 \mathrm{~b}$ (through Section 376-U1527C-11R-3), the matrix has a perlitic texture and further grain-size reduction by hydraulic fracturing (Figure F14C). Furthermore, hydrothermal fluids pervasively affected both crystals and the surrounding trachytic matrix. With depth, this matrix is increasingly replaced by secondary quartz. The original matrix consists of $\sim 20$ vol\% plagioclase, approximately $<1$ vol\% clinopyroxene, and $\sim 0.5 \mathrm{vol} \%$ anhedral to subhedral magnetite, and the remaining $\sim 78 \%$ is completely altered volcanic ash. This altered ash becomes overprinted by secondary quartz (Figure F14F), chlorite, and clay, with minor euhedral pyrite in the lower parts of Subunit 2b. Sulfide phases are often located adjacent to magnetite (see Alteration). Quartz veinlets $(<0.5 \mathrm{~mm})$ cut both matrix and clasts in this subunit. The plagioclase in the matrix appears unaltered.

\section{Igneous Subunit 2c}

Interval: $376-\mathrm{U} 1527 \mathrm{C}-17 \mathrm{R}-2,83 \mathrm{~cm}$, to $18 \mathrm{R}-2,150 \mathrm{~cm}$ Depth: 220.98-226.49 mbsf

Lithology: altered clast-supported, polymict lapillistone, sometimes with blocks/bombs

Igneous Subunit 2c consists of clast-supported, polymict lapillistone that is generally poorly sorted and contains a significant portion of blocks/bombs in Section 376-U1527C-18R-1. This subunit is distinguished from the overlying subunit by a lower matrix-to-clast ratio, its color, and a different style of alteration (see Alteration). The dominant color is bluish gray, modified by varying degrees of alteration of individual clasts and the matrix. The matrix is cemented, highly altered, and fine grained and often exhibits fluidal textures and veins (see Alteration). Clasts range in size from granules to cobbles, are subrounded to subangular, and appear volcanic in origin (Figures F12, F16). We distinguished two types of clasts, listed here in order of their relative abundance (high to low abundance):

- Clast Type 2c-1: light green to gray, moderately altered, finegrained volcanic clasts; some contain plagioclase. These are similar to Clast Type 2b-1 (in Subunit 2b).

- Clast Type 2c-2: macroscopically, these dark, fine-grained volcanic clasts appear fresh to slightly altered, and some contain plagioclase and relatively abundant fine-grained sulfides. Microscopically, clasts of this type in Sample 18R-1, 82-84 cm (thin section [TS] 21; Figure F16) show a greater degree of alteration compared to the dark, fine-grained clasts of Subunit 2b (see Alteration). 
Figure F15. Representative images of the three clast types in Subunit 2b, Hole U1527C. A-C. Type 2b-1: (A) macroscopic image and (B, C) microscopic images with adjacent matrix (boundary marked by the stippled line) in (B) PPL and (C) XPL. D-F. Type 2b-2: (D) macroscopic image and (E, F) microscopic images in (E) PPL and (F) XPL. G-I. Type 2b-3: (G) macroscopic image and (H, I) microscopic images in (H) PPL and (I) XPL. Plag = plagioclase, $\mathrm{Cpx}=\mathrm{clinopyroxene}$.
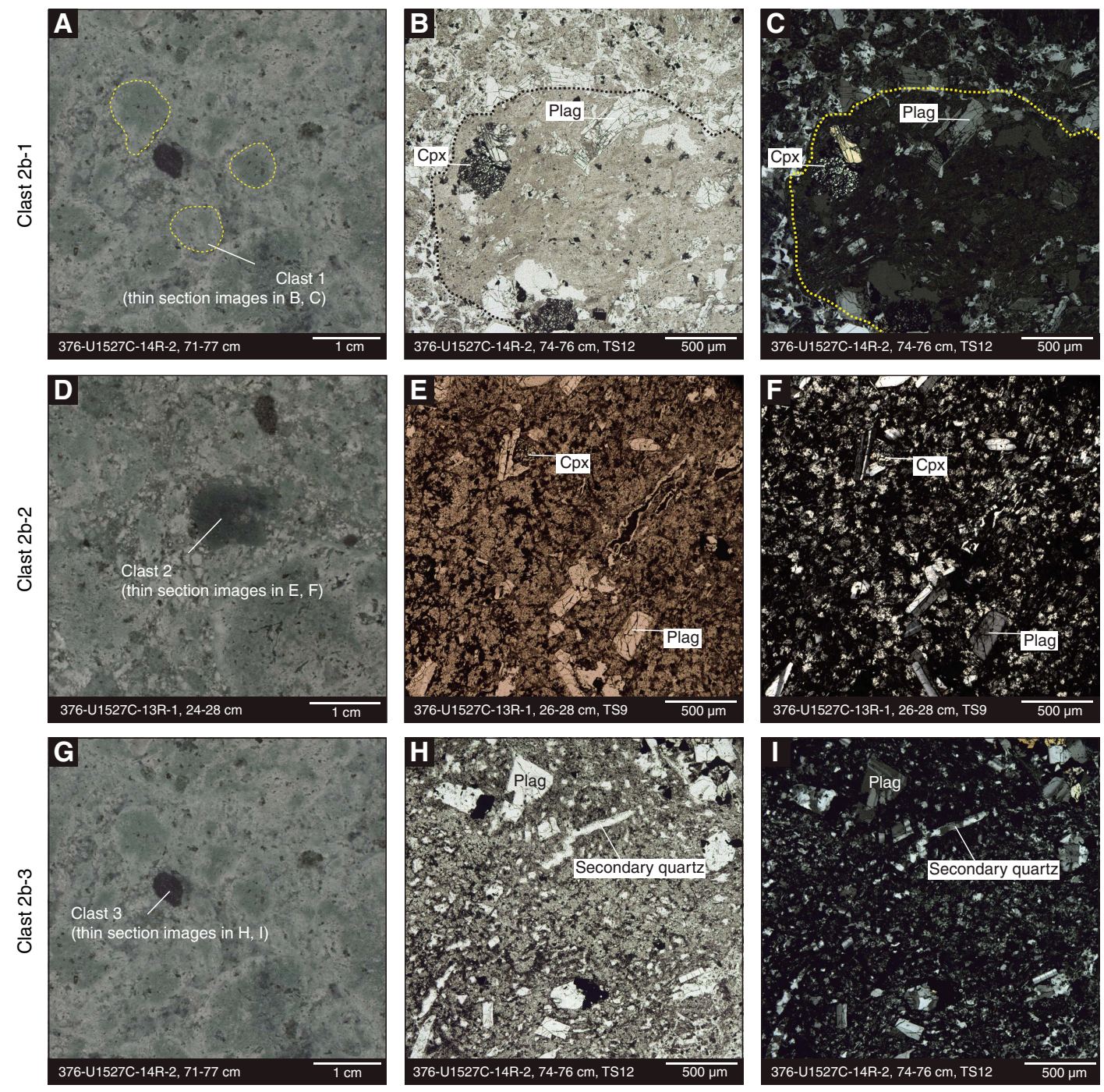

In contrast to the overlying Subunit $2 \mathrm{~b}$, the individual clasts in Subunit 2c appear less vesicular and lack aligned and elongate vesicles.

Plagioclase in Subunit 2c (5 vol\%) shows zoning and twinning, whereas pyroxene is absent (Figures F14, F16). The matrix contains perlitic areas resembling the trachytic groundmass of the dacitic protolith, as well as areas where the original matrix has been replaced by secondary quartz (cf. the lower parts of Subunit 2b). Fractured crystals were observed in certain thin section domains, supporting macroscopic observations of grain-size reduction (see Structural geology).

\section{Igneous Subunit 2d}

Interval: $376-\mathrm{U} 1527 \mathrm{C}-19 \mathrm{R}-1,0 \mathrm{~cm}$, to $20 \mathrm{R}-1,114 \mathrm{~cm}$

Depth: 228.40-234.38 mbsf

Lithology: altered matrix- and clast-supported, polymict lapillituff and clast-supported, monomict tuff-breccia

Igneous Subunit $2 \mathrm{~d}$ consists of hydrothermally altered matrixand clast-supported, polymict lapilli-tuff and clast-supported, monomict tuff-breccia that are bluish gray to greenish gray in color with poor sorting. This subunit is distinguishable from Subunit 2c by a more homogeneous color and a higher matrix-to-clast ratio. The matrix is fine grained, cemented, and probably represents highly altered tuff. The subangular to subrounded clasts range in size from granules to cobbles and are volcanic in origin (Figure F12D). We distinguished the following two clast types, listed in order of their relative abundance (high to low):

- Clast Type 2d-1: light green, moderately altered, plagioclasebearing volcanic clasts (Figure F17) similar to Clast Types $2 \mathrm{~b}-1$ and $2 \mathrm{c}-1$. Thin section observations showed that Type $2 \mathrm{~d}-1$ clasts contain $\sim 20$ vol\% primary plagioclase phenocrysts and glomerocrysts that are only slightly altered, with a maximum size range of $2-5 \mathrm{~mm}$ and an average size of $0.2-0.5 \mathrm{~mm}$. Secondary minerals in the clasts are dominated by $\sim 50$ vol\% quartz, $\sim 30$ vol\% chlorite with minor ( 20 vol\%) clays, and 1 vol\% sulfide. No original vesicles are present in the clasts. However, in a few clasts, the shape of secondary quartz suggests that it infilled vesicles that were aligned and elongated, possibly resembling 
Figure F16. Representative images of the two clast types in Subunit 2c, Hole U1527C. A-C. Type 2c-1: (A) macroscopic image and (B, C) microscopic images with the surrounding matrix in (B) PPL and (C) XPL. Images show that plagioclase (Plag) phenocrysts and microlites persist in the altered groundmass of the clast. D-F. Type 2C-2: (D) macroscopic image and (E, F) microscopic images with the surrounding matrix in (E) PPL and (F) XPL. Images D-F show the very altered phenocrysts, the groundmass of the clast, and the relative abundance of sulfide compared to other clast types.
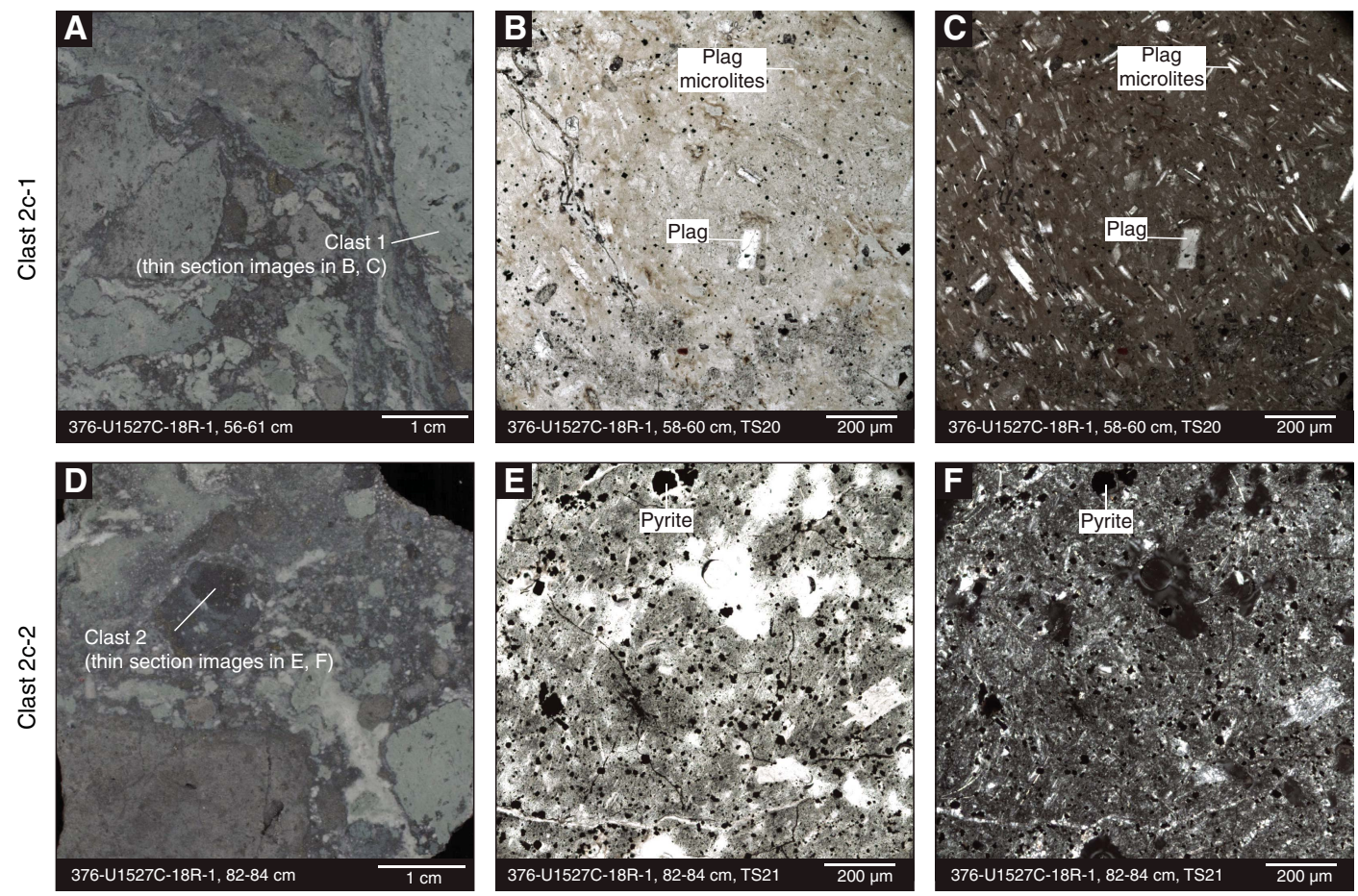

fiamme-like textures. The matrix surrounding the clasts is poorly sorted and contains 40-50 vol\% cryptocrystalline chlorite and clay, $30 \mathrm{vol} \%$ quartz, $15-20$ vol\% fractured and slightly altered plagioclase, and 1 vol\% pyrite grains and pyrite aggregates.

- Clast Type 2d-2: black, fine-grained clasts, sometimes with sulfides and/or laminated textures, that are macroscopically similar to Clast Type 2c-2. No thin sections of this clast were sampled.

As in Subunit 2c, some domains in the matrix exhibit perlitic textures of a trachytic groundmass, whereas in others, secondary quartz has replaced the original mineral assemblage. Plagioclase in the clasts and the matrix still shows oscillatory zoning and albite twinning, particularly in crystals $>1 \mathrm{~mm}$, attesting to their ability to preserve original volcanic textures and composition in moderately to intensely altered rocks. Relict glomerocrysts and pseudomorphs of quartz after pyroxene were more rarely observed.

\section{Interpretation}

\section{Igneous Unit 1}

The plagioclase- and clinopyroxene-bearing dacite lavas of Igneous Unit 1 are similar in many respects to published descriptions of the petrography and whole-rock geochemistry of rocks from Brothers volcano (e.g., Wright and Gamble, 1999; Haase et al., 2006; Timm et al., 2012). Petrographically, Igneous Unit 1 samples have low abundances of plagioclase and clinopyroxene phenocrysts that are similar in shape to those reported in Wright and Gamble (1999). The samples contain glomerocrysts of plagioclase, clinopyroxene, and magnetite, presumably grown in a subvolcanic magma reservoir or conduit before eruption. The abundance of plagioclase microlites in the groundmass of the dacites with swallow-tail quench textures attests to the sudden eruption and rapid cooling of the samples.

Analyses of rock powders by pXRF (Table T5) confirm the dacitic composition of the fresh lavas from Igneous Unit 1 encountered in Hole U1527A and in the upper section of Hole U1527C; both are very similar to the dacite compositions previously reported from Brothers volcano (Wright and Gamble, 1999; Haase et al., 2006; Timm et al., 2012).

Although no contacts with other units were recovered, the unaltered plagioclase-phyric dacite lava is interpreted to be an autobrecciated lava flow because of its distance from the presumed (and now missing) central cone and from sloping linear features imaged with seismic reflectors near the rim of the caldera (Figure F2) (de Ronde et al., 2017).

Based on low recovery and poor hole stability (see Operations), it appears that Site U1527 has a 185 m thick overburden of unconsolidated volcanic material. Because of the volcaniclastic material recovered from Igneous Unit 1, this overburden probably contains mostly scoria of varying vesicularity and fluidal textures as well as subordinate pumice clasts. These pyroclasts most likely surround blocks/bombs of fresh dacite lava (autobrecciated lava flow). Unfortunately, poor recovery and drilling-induced disturbances of sorting, grading, and component ratios limit any further constraints on the stratigraphic relationships. Pumice has not been reported for Brothers volcano to date, although that does not preclude a Brothers volcano origin. However, it cannot be discounted that the pumice clasts are rafted debris from an explosive eruption from nearby volcanoes along the Kermadec arc. 
Figure F17. Dominant Clast Type 2d-1 in Subunit 2d, Hole U1527C. A. Macroscopic image of altered light green clasts. B, C. Microscopic images from within the clast in (B) PPL and (C) XPL. Plag = plagioclase.
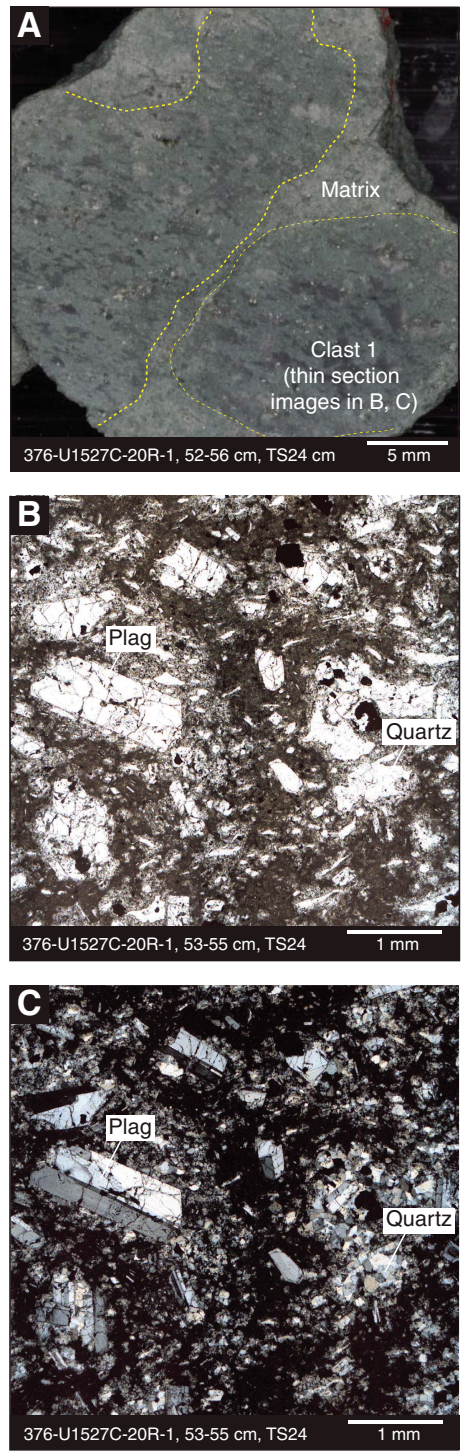

\section{Igneous Unit 2}

pXRF measurements of the Subunit $2 b-2 d$ volcanic clasts and matrix reveal evidence of the compositional changes typical of hydrothermal alteration, such as the mobilization (and mostly loss) of the fluid-mobile elements $\mathrm{K}$ and $\mathrm{Rb}$. Nevertheless, alteration-immobile elements $\mathrm{Zr}$ and $\mathrm{Y}$ suggest that the original composition of the clasts was similar to that of the unaltered dacite from Unit 1 and Subunit 2a (Table T5). These data support the hypothesis that the volcaniclastic deposits originally consisted of lava clasts embedded in volcanic ash of the same composition that were subsequently altered by hydrothermal fluids (de Ronde et al., 2005). The fact that the matrix is altered to a greater degree than the clasts suggests that the deposit was unconsolidated and the higher permeability of the matrix allowed the fluids to traverse and alter it more easily.

One possible model for the volcanic emplacement and primary fragmentation of the volcaniclastic sediments is gravitational collapse (flank collapse) of a massive lava formation, such as a lava flow or a lava dome, which would result in a debris flow. Other possible models include primary emplacement as pyroclastic deposits, such as by explosive eruptions, interaction of lava flows with seawater (forming hyaloclastites), or a submarine pyroclastic flow, which could stem both from an explosive eruption or the gas-driven collapse of a lava dome (e.g., Fisher and Schmincke, 1984).

The most common clast types of Subunits $2 b-2 d$ are all very similar, suggesting a common protolith. Subunit $2 \mathrm{~b}$ contains two other clast types, both more altered than Type $2 \mathrm{~b}-1$ clasts and sometimes entrained in Type $2 \mathrm{~b}-1$ clasts. Even though more detailed studies are required to resolve the detailed relationships and relative timing of brecciation and alteration, a possible hypothesis may be that both Type $2 b-2$ and $2 b-3$ clasts represent xenoliths of older, hydrothermally altered dacite entrained in the Type $2 \mathrm{~b}-1$ clasts during its eruptive emplacement. The Type $2 c-2$ and $2 d-2$ clasts of Subunit $2 \mathrm{c}-2 \mathrm{~d}$ are similar and may represent equivalents to Type $2 b-2$ clasts of Subunit $2 b$, but further investigation is needed into the detailed petrographic relationships. It is clear, however, that several fragmentation and alteration stages must have affected Igneous Unit 2. Clasts in the same core sections show different degrees of alteration. In addition, some clasts contain hydrothermal (secondary mineral) veins that do not project into the surrounding matrix, suggesting secondary brecciation after alteration of the pyroclastic deposits had already taken place. Secondary brecciation may have been due to movement along the ring faults surrounding the caldera, gravitational collapses due to slope instabilities, or possibly hydrothermal explosions. The fact that there is virtually no alteration above Unit 2 suggests either an impermeable zone between Units 1 and 2 or a significant time difference between these two units. If the latter is true, then the top of Unit 2 represents a paleoseafloor upon which Unit 1 was deposited after the hydrothermal activity affecting Unit 2 had ceased.

\section{Alteration}

The overall intensity of alteration from Site U1527 increases with depth (Figure F18), and three distinct alteration types (I-III) were identified (Figures F19, F20). Alteration Types I and II are both divided into subtypes (Ia/Ib and IIa/IIb, respectively). These types are classified based on a dominant alteration mineral assemblage complimented by various textural features. Alteration Type I reflects a relatively low level of hydrothermal alteration. Alteration Types II and III reflect higher degrees of alteration and are distinguished by the presence of specific alteration mineral assemblages. Alteration Subtypes Ib and IIb reflect a later stage alteration overprint of the dominant alteration mineral assemblage defined by $\mathrm{Al}$ teration Subtypes Ia and IIa, respectively. The alteration assemblages represent minerals that have precipitated both as a result of transformation of primary igneous minerals and direct precipitation from hydrothermal fluids.

\section{Alteration Subtype la}

Distinguishing alteration minerals: goethite + mordenite + palagonite + pyrite \pm illite \pm smectite

Degree of alteration: slightly altered

Intervals: 376-U1527A-4R-CC, $0 \mathrm{~cm}$, to 9R-CC, $1 \mathrm{~cm}$; 376U1527C-3R-1, $0 \mathrm{~cm}$, to 10R-1, $56 \mathrm{~cm} ; 11 \mathrm{R}-1,24-52 \mathrm{~cm}$

Depths: Hole U1527A = 29.10-67.81 mbsf; Hole U1527C = 108.40-176.16 and 185.44-185.72 mbsf

Alteration Subtype Ia is defined by the presence of minor goethite, mordenite, palagonite, and pyrite with trace illite and smectite altering the primary igneous mineral phases that still dominate samples at these depth intervals (Tables T2, T3; Figure F21; 
Figure F18. Alteration and abundances of key alteration minerals, Site U1527.

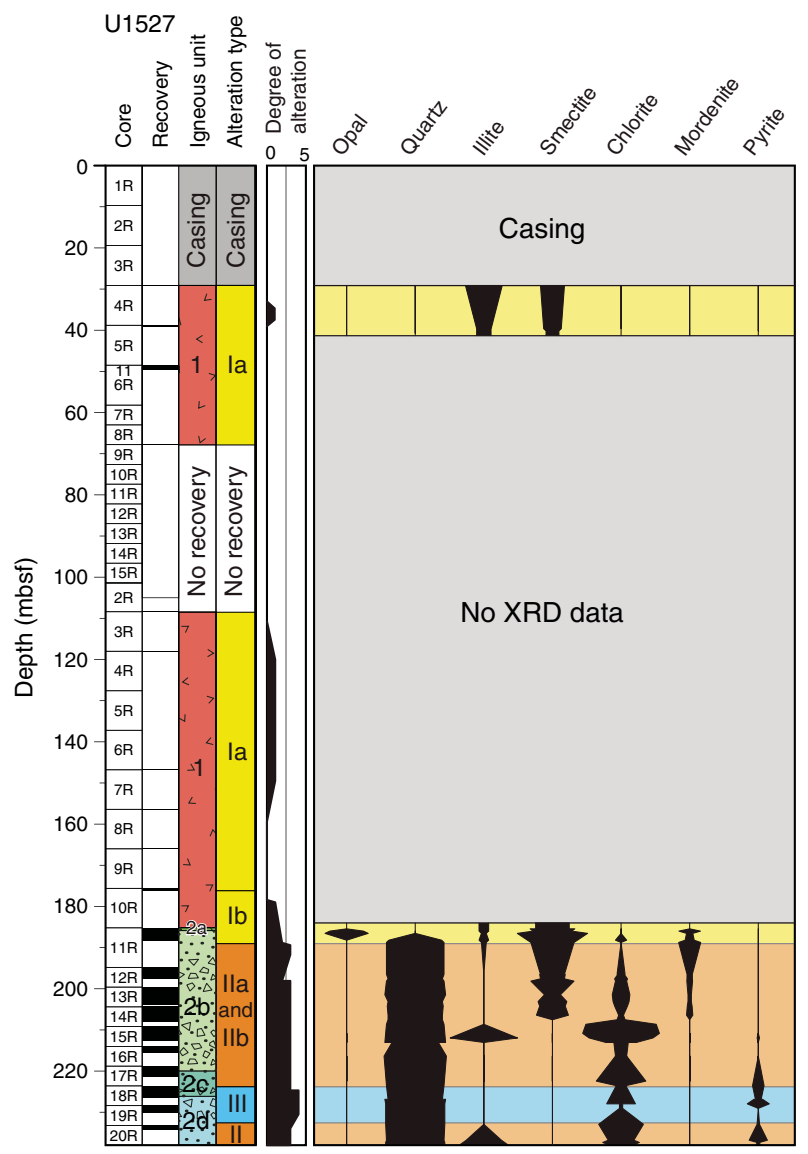

see Igneous petrology and volcanology). The dacitic and polymict dacitic to rhyolitic pumiceous fragments of Igneous Unit 1 are either unaltered or show evidence of only slight alteration $(<5 \mathrm{vol} \%$ alteration minerals). The groundmass is characterized by perlitic textures and volcanic glass that is variably altered to palagonite (Figure F21). Goethite, mordenite, palagonite, and rare pyrite are the only alteration minerals identified visually in the core. Illite and smectite were identified by X-ray diffraction (XRD). The inner walls of vesicles are commonly lined by disseminated pyrite or goethite and/or are partially infilled by mordenite or palagonite. The distribution of vesicle-infilling mordenite or palagonite throughout this section of the core is variable. Trace skeletal pyrite crystals also occur in association with magnetite in the groundmass (Figure F21).

\section{Alteration Subtype lb}

Distinguishing alteration minerals: goethite + opal + mordenite \pm illite \pm smectite \pm quartz

Degree of alteration: moderately altered

Interval: 376-U1527C-11R-1, 0-24 cm

Depth: 185.20-185.44 mbsf

Alteration Subtype Ib is characterized by orange-red goethite, opal, and mordenite with minor illite and smectite (Figure F22). XRD analysis of Sample 376-U1527C-11R-1, 15.0-16.0 cm, confirms the presence of minor mixed-layer illite-montmorillonite, opal, and quartz. Primary plagioclase and pyroxene phenocrysts persist in the samples and exhibit incipient alteration along cleavage traces. This alteration type is distinguished from Alteration Subtype Ia by the higher abundance of goethite, clay minerals, and opal, which replace groundmass, vesicle rims, and locally cut and fragment small feldspar grains (Figure F22). Vesicles are variably filled with mordenite or lined with goethite (Figure F22). The contact between dacitic clasts and the surrounding matrix is typically abrupt, with no evidence of resorption or an increase in alteration toward the clast margins (Figure F22). However, in rare cases, alteration halos surrounding some clasts are present.

\section{Alteration Subtype lla}

Distinguishing alteration minerals: chlorite + quartz + illite + smectite \pm mordenite

Degree of alteration: highly altered

Intervals: $376-\mathrm{U} 1527 \mathrm{C}-11 \mathrm{R}-1,52 \mathrm{~cm}$, to $17 \mathrm{R}-2,83 \mathrm{~cm}$; $19 \mathrm{R}-1,0$ $\mathrm{cm}$, to $20 \mathrm{R}-1,118 \mathrm{~cm}$

Depths: $185.72-220.98$ and 228.40-234.38 mbsf

Alteration Subtype IIa is characterized by the presence of abundant chlorite, quartz, illite, and smectite with minor mordenite (Figures F19, F23; Table T2). Smectite is common in the upper intervals of Alteration Type II (both a and b) but is not present below 200 mbsf. Illite and mordenite both occur throughout these intervals but in relatively low abundances $(<5$ vol\%). The first appearance of Alteration Subtype IIa coincides with the first occurrence of Igneous Unit 2. Primary plagioclase and magnetite are present within variably altered clasts throughout this alteration type. Augite is present in the less-altered clasts but notably absent in the more-altered clasts. The degree of alteration of both clasts and matrix, as well as within the clast population, varies between moderately, highly, and intensely altered (see Table T7 in the Expedition 376 methods chapter [de Ronde et al., 2019a]).

The matrix is primarily altered to chlorite, with acicular illite and minor opal. Perlitic textures are locally preserved with spherulites developed in feldspar phenocrysts. Euhedral to subhedral plagioclase and augite phenocrysts persist within the matrix but are more sparsely distributed and partially replaced by chlorite along cleavage planes.

Boundaries of individual clasts are variable in appearance. Some exhibit diffuse contacts due to extensive resorption, whereas others are characterized by well-defined sharp boundaries (Figure F24). With increasing depth, vesicle-fill mineralogy gradually transitions from mordenite to a silica-, pyrite- and magnetite-dominated assemblage; however, it is unclear whether the magnetite is primary or secondary. Below $214 \mathrm{mbsf}$, the abundance of disseminated pyrite increases from $<0.5$ to $>1 \mathrm{vol} \%$. Based on visual observation, magnetite abundance peaks at $220 \mathrm{mbsf}$ at $3-4 \mathrm{vol} \%$ and then decreases with increasing depth as pyrite and silica contents increase. Rare chalcopyrite grains are observed in hand specimens at 221.0 and 228.4 mbsf and in thin section at 209.4 mbsf (Figure F25).

\section{Alteration Subtype IIb}

Distinguishing alteration minerals: chlorite + quartz + goethite \pm illite \pm smectite \pm mordenite

Degree of alteration: highly altered

Intervals: 376-U1527C-11R-1, 120-145 cm; 11R-2, 0-22 cm; $11 \mathrm{R}-2,118-133 \mathrm{~cm} ; 11 \mathrm{R}-3,0-33 \mathrm{~cm} ; 12 \mathrm{R}-1,0-19 \mathrm{~cm} ; 13 \mathrm{R}-$ 1, 5-22 cm; 13R-2, 52-126 cm; 14R-1, 0-22 cm; 14R-1, 39$77 \mathrm{~cm} ; 14 \mathrm{R}-2,0-27 \mathrm{~cm} ; 14 \mathrm{R}-3,96-141 \mathrm{~cm} ; 16 \mathrm{R}-1,0-36 \mathrm{~cm}$ Depth: $186.40-215.36 \mathrm{mbsf}$ 
Figure F19. Representative intervals of alteration types, Hole U1527C. A. Subtype la: unaltered to slightly altered clast of dacite. B. Subtype Ib: dark, unaltered clasts of dacite with well-defined boundaries surrounded by altered, yellow-brown matrix. C. Subtype lla: pervasively altered clasts surrounded by chloritealtered matrix. D. Overprint of Subtype Ilb onto Subtype Ila. E. Type III: pervasively altered clasts with resorbed, gradational boundaries.
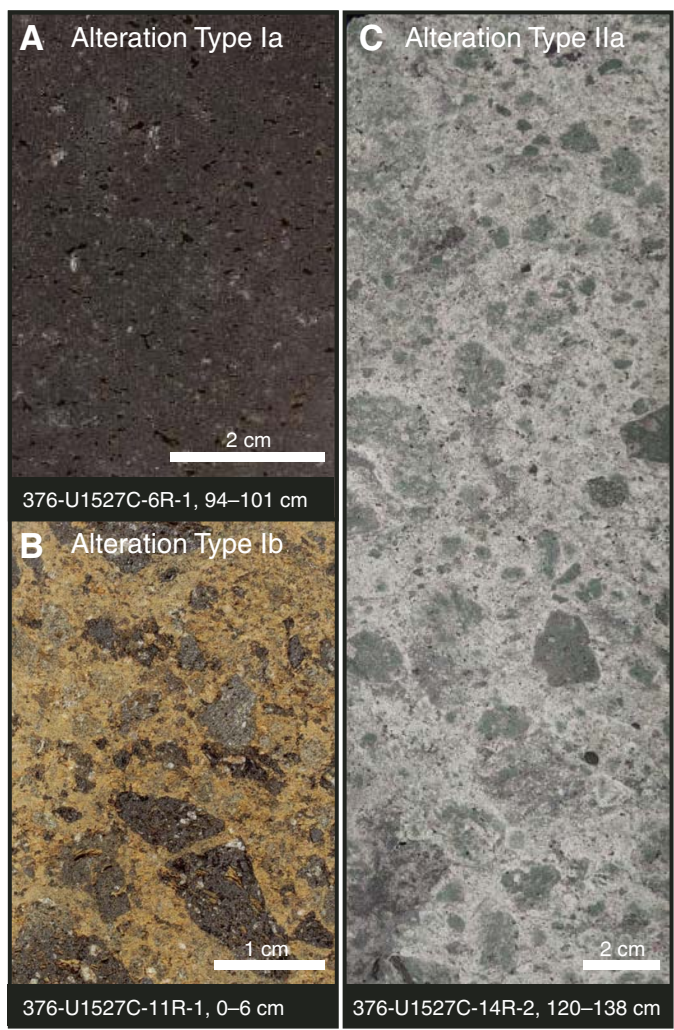

Figure F20. Downhole distribution of alteration types, Holes U1527A and U1527C.

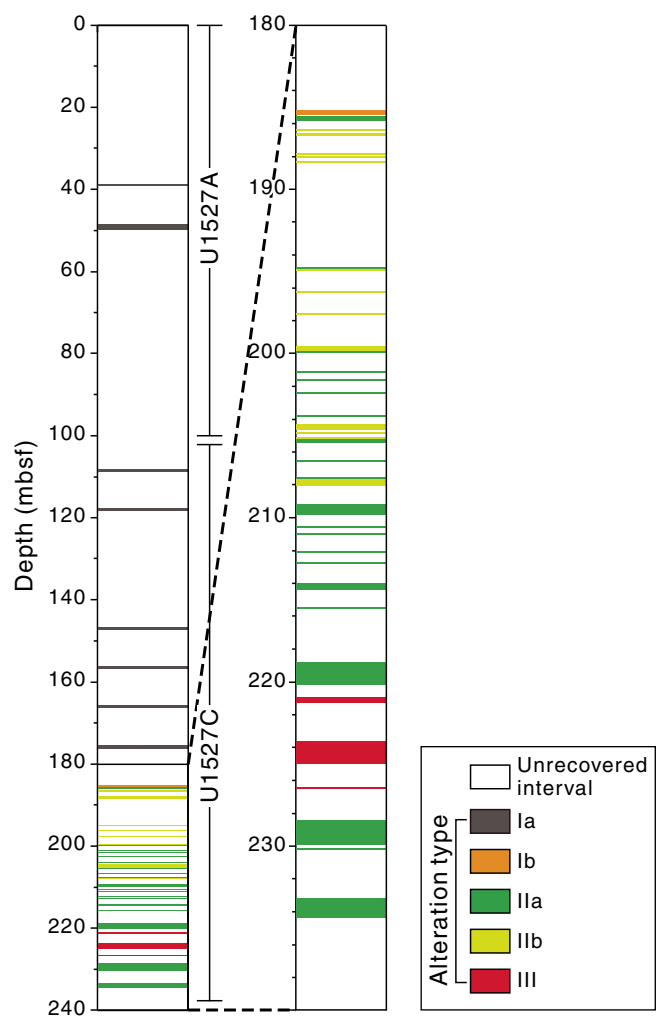

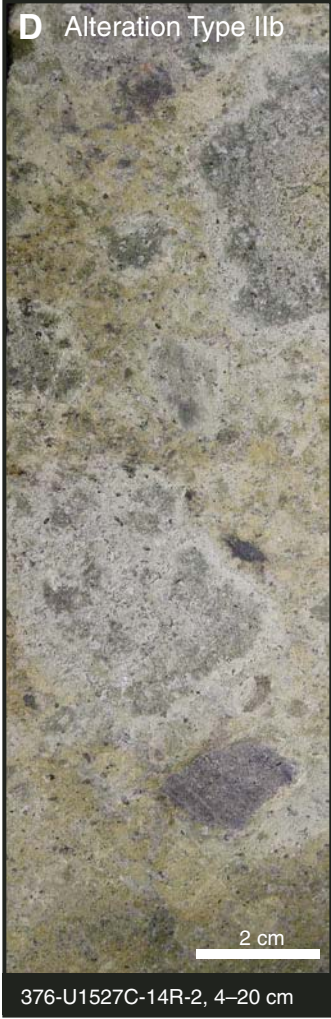

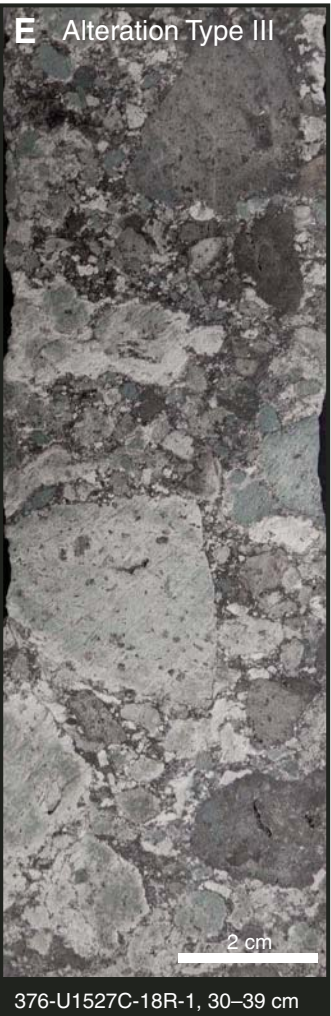

Table T2. Key alteration minerals by X-ray diffraction (XRD), Holes U1527A and U1527C. Download table in CSV format.

Table T3. Key alteration minerals by X-ray diffraction (XRD) (postcruise), Holes U1527A and U1527C. Download table in CSV format.

Alteration Subtype IIb is heterogeneously distributed at several depth intervals and largely interlayered with Alteration Subtype IIa, having a similar alteration assemblage that is dominated by quartz and chlorite (Table T2). However, a distinct color change from green-gray to yellow-brown coincides with an increased presence of goethite that replaces the groundmass (cf. Figures F23 and F47, which show clearly distinguishable reflectance colorimetry signatures between Alteration Subtypes IIa and IIb). The contacts between Alteration Subtypes IIa and IIb are sharp and irregular (Figure F23). The clasts range from slightly to intensely altered dacite, with primary minerals replaced by chlorite, quartz, and/or clay minerals. The outlines of the clast margins vary from sharp to completely resorbed, similar to Alteration Subtype IIa. Vesicles are invariably infilled with mordenite and pyrite.

\section{Alteration Type III}

Distinguishing alteration minerals: quartz + chlorite + pyrite \pm illite

Degree of alteration: highly altered

Intervals: 376-U1527C-17R-2, 83-112 cm; 18R-1, 0-139 cm; 18R-2, 0-150 cm

Depth: 220.98-226.49 mbsf 
Figure F21. Alteration Subtype la. A. Dacitic lava in hand specimen. B. Alteration of primary volcanic glass to palagonite (Palag). C. Primary magnetite (Mt) and globular pyrite (Py). $\mathrm{RL}=$ reflected light.
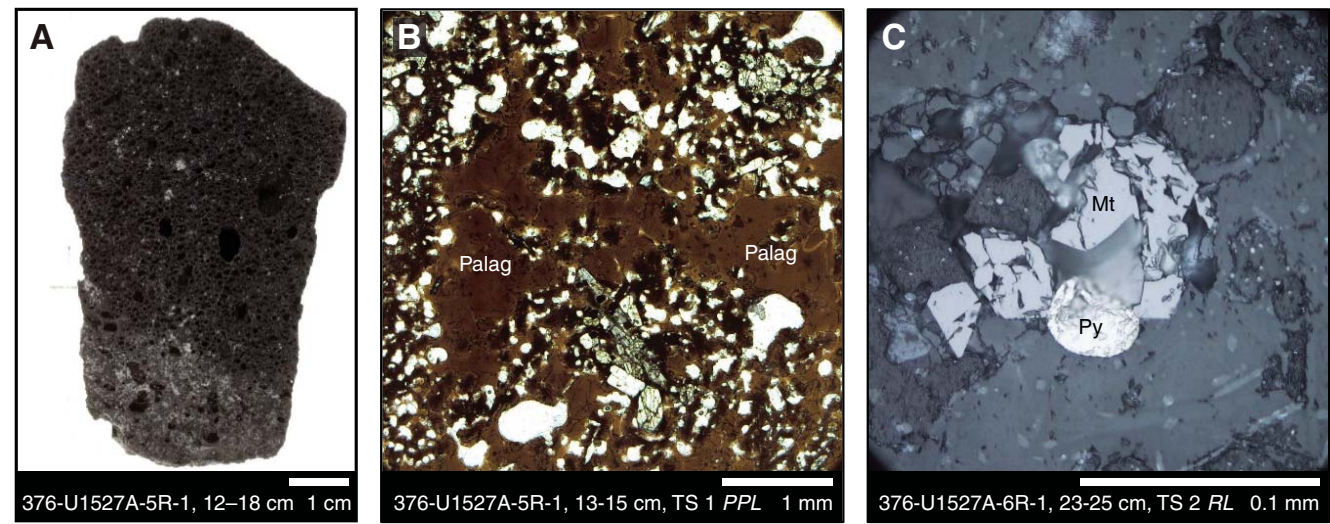

Figure F22. Alteration Subtype Ib. A. Dacite showing alteration of matrix to goethite. B. Zeolite (mordenite) infilling vesicles. C. Dacite clast (red outline) in a goethite-rich matrix. Note sharp clast-matrix boundary. D. Goethite in smectite-rich matrix.
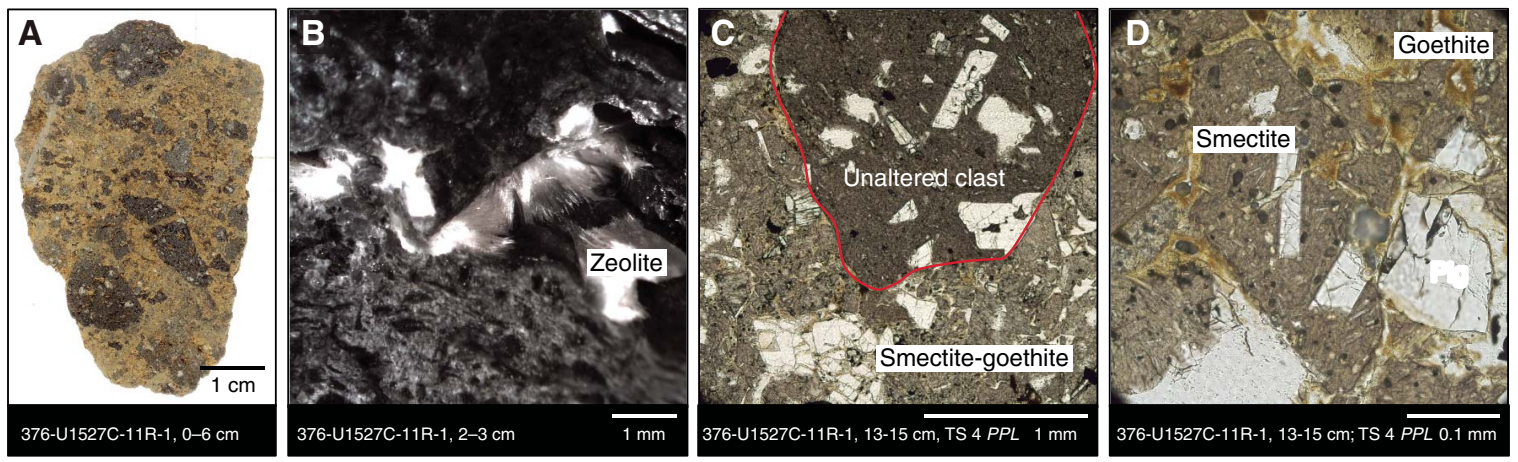

Figure F23. Alteration Type II. A. Typical appearance of Subtype Ila. B. Sharp boundary between Subtype Ilb (top) and Ila (bottom). C. Typical appearance of Subtype Ilb. D. Typical mineral assemblage in matrix associated with Subtype lla: fine-grained chlorite (Chl)-quartz (Qtz)-smectite matrix with unaltered plagioclase phenocrysts (Plg). E. Perlitic texture with chlorite-filled vugs in Subtype Ilb.
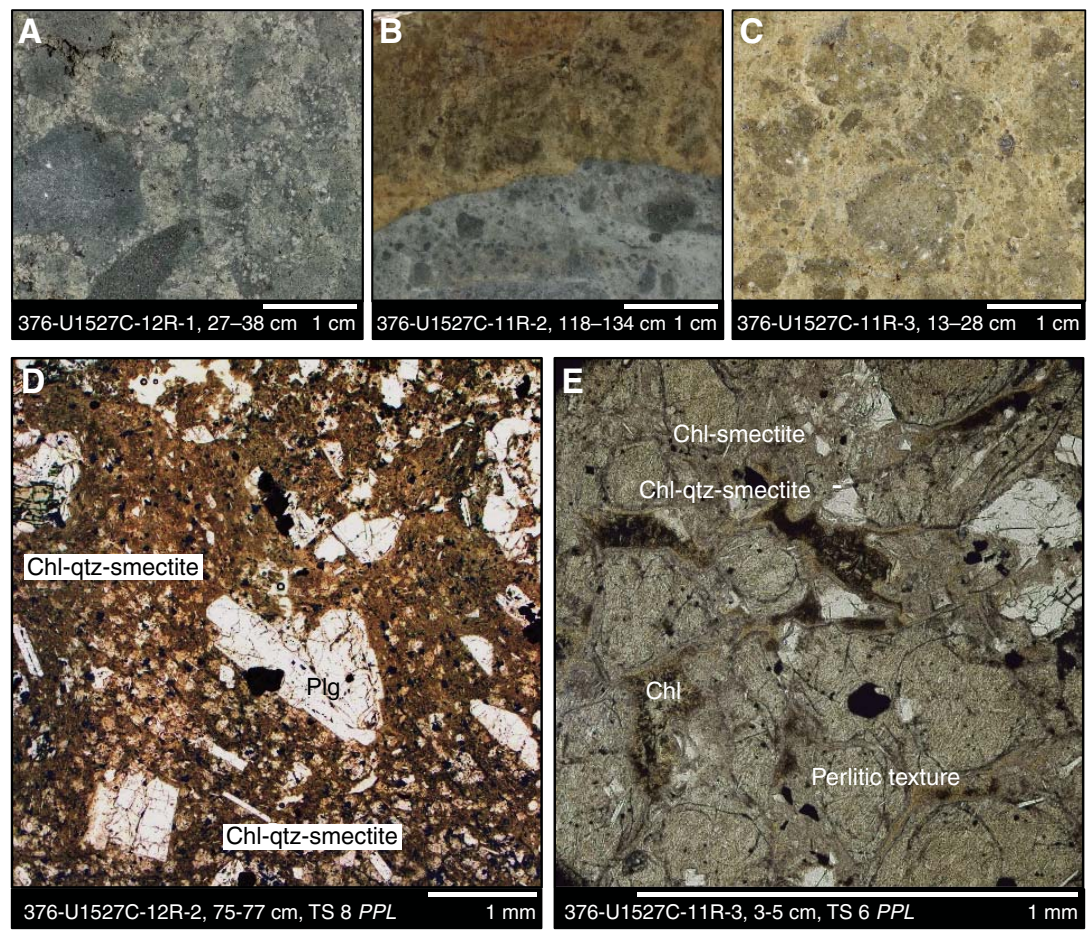
Figure F24. A-C. Clasts associated with Alteration Subtype lla exhibit varying degrees of resorption, ranging from (A) no resorption with sharp clast margins to (C) total resorption where margins are no longer distinguishable.
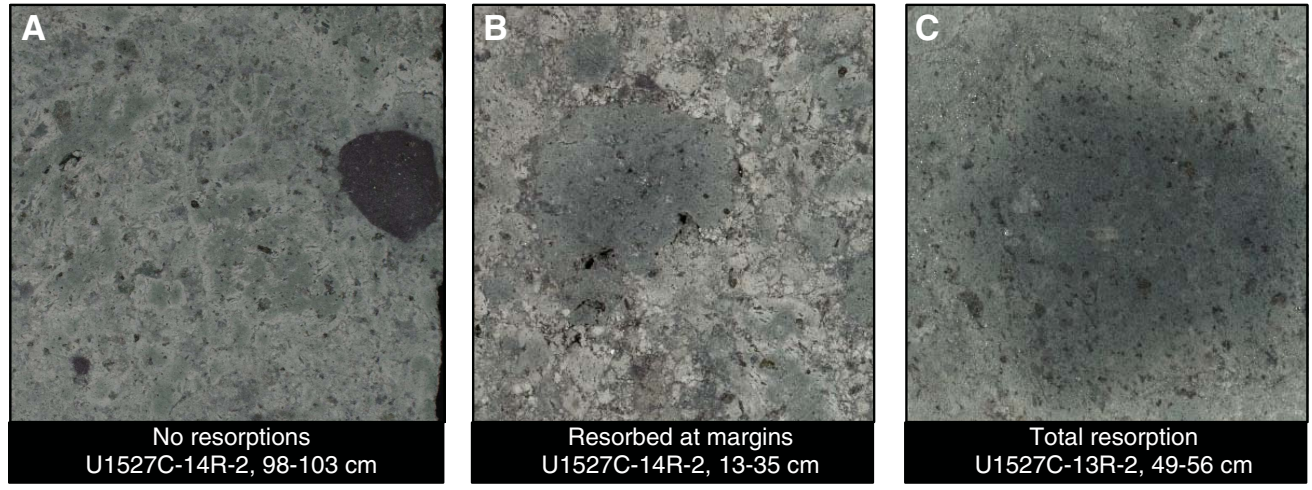

Figure F25. Typical sulfide mineral assemblage in Alteration Subtype Ila showing minor magnetite (Mt), pyrite (Py), and chalcopyrite (Cpy).

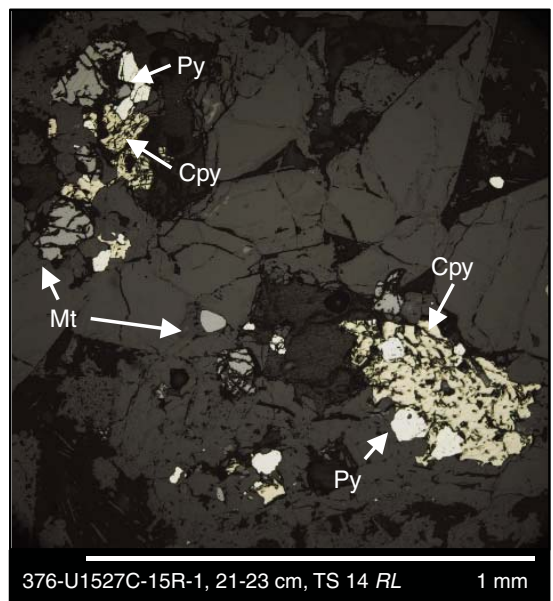

Alteration Type III is characterized by an assemblage of quartz, chlorite, and pyrite with minor illite (Figure F19; Table T2). Relict original plagioclase and augite phenocrysts are largely restricted to clasts. Smectite is absent. Clast boundaries appear sharp and are clearly discernible (Figure F26); however, the degree of alteration within individual clasts is variable. Larger clasts commonly show millimeter-scale reaction rims of pyrite and silica.

Variable clast types are distinguishable by color and range through shades of light green to dark gray to black (Figure F26). Green clasts are highly altered and contain abundant chlorite. Light gray clasts are variably altered with vesicles infilled by quartz and pyrite. The dark gray to black clasts were initially interpreted to be the least altered clasts in this part of the core. However, thin section observations confirmed the presence of abundant silica, pyrite, and magnetite, indicating the clasts exhibit the highest degree of alteration within this alteration type (Figure F26). The dark clasts also display the highest enrichment in $\mathrm{K}_{2} \mathrm{O}, \mathrm{Ba}$, and $\mathrm{S}$ and depletion in $\mathrm{MgO}$ (see Geochemistry), consistent with extensive alteration.
The matrix is pervasively altered to a chlorite + quartz + pyritedominated alteration assemblage (Figure F26) with minor illite, disseminated magnetite $(<1 \mathrm{~mm})$, and minor chalcopyrite. Pyrite exhibits a strong spatial association with silica, forming both a matrix constituent-commonly exceeding 5 vol\% of the sample-and vesicle infill within the clasts. Magnetite occurs as coarse grains associated with sparse to moderately altered and fractured plagioclase that occurs within the clasts. Plagioclase often exhibits some degree of disaggregation and is rarely present as unaltered tabular phenocrysts; rather, it forms subrounded aggregates with chlorite alteration along fractures (Figure F26). Localized, pervasive alteration occurs over short intervals with distinct veins of clay + silica-dominated material associated with masses of finely disseminated pyrite (Figure F26).

\section{Synthesis and interpretation}

The overall intensity of alteration of the rocks at Site U1527 increases with depth. When combined with downhole changes in alteration mineralogy such as changes in the silica polymorph from opal to quartz, increasing amounts of chlorite, and loss of smectite and mordenite, this increase in alteration intensity suggests gradually rising alteration temperatures (Figure F18).

Abundant mordenite and opal, characteristic of alteration and hydration of volcanic glass matrix at temperatures $<150^{\circ} \mathrm{C}$, are restricted to the upper $\sim 185$ mbsf of Site U1527 (i.e., Alteration Subtypes Ia and Ib). Smectite is included in this inferred lower temperature mineral assemblage that characterizes Alteration Type I, but its occurrence also extends into the upper $\sim 25 \mathrm{~m}$ of the interval characterized by Alteration Type II (i.e., to $200 \mathrm{mbsf}$ ). Goethite was also observed at these shallower intervals and sporadically to 215 mbsf, likely in response to the ingress of seawater. Quartz first becomes abundant below $\sim 160 \mathrm{mbsf}$, where it forms a dominant alteration mineral in Alteration Types II and III. The presence of chlorite coincides with quartz and remains a dominant alteration phase throughout the deeper intervals of Hole U1527C (Figure F18). 


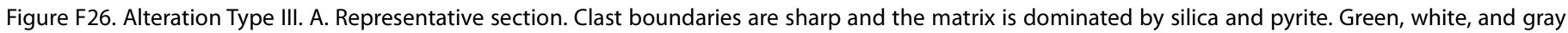

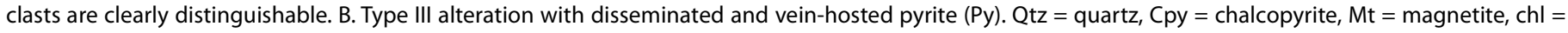

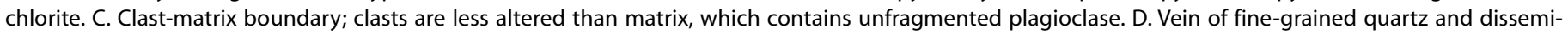
nated pyrite within a quartz-chlorite matrix; plagioclase (plg) exhibits no alteration.
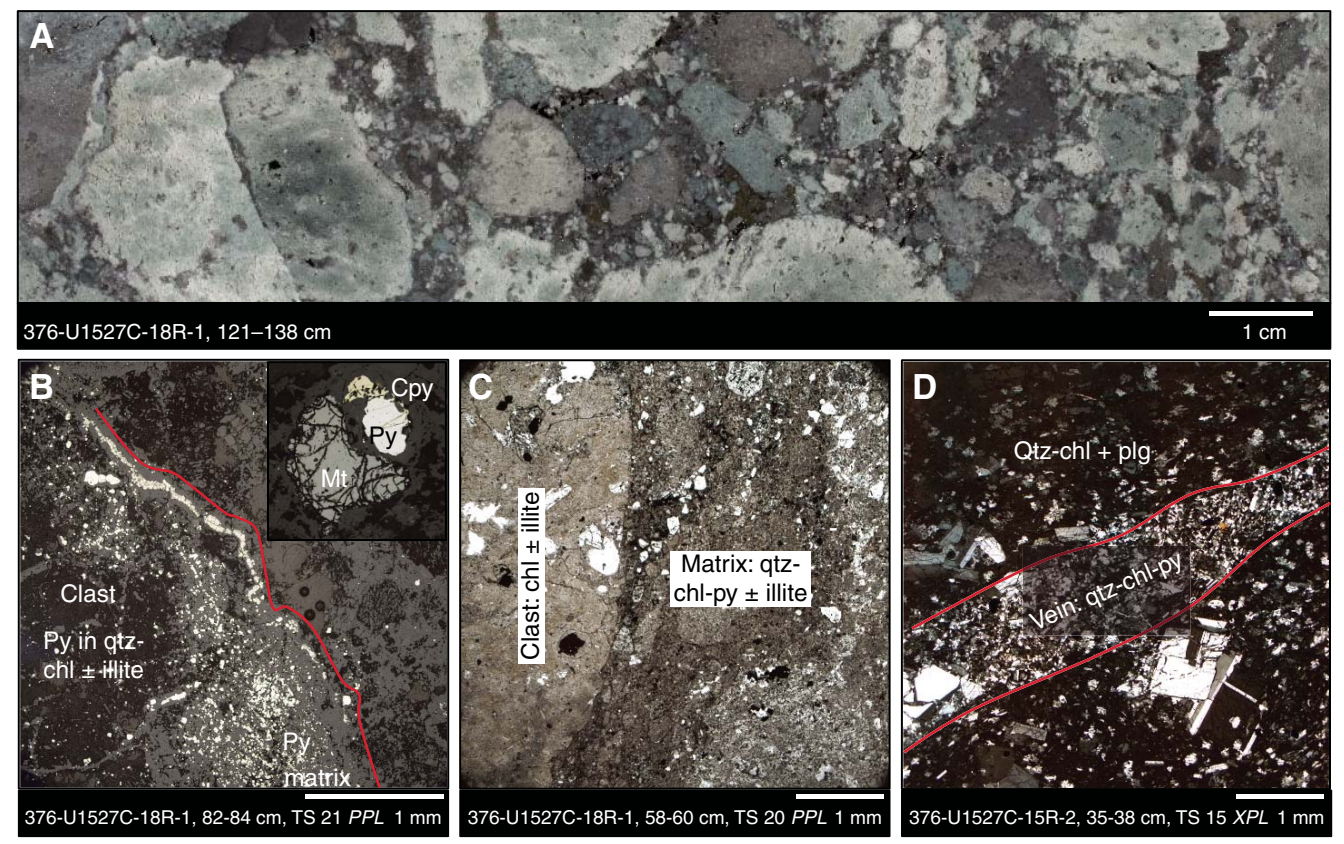

\section{Structural geology}

\section{Hole U1527A: Igneous Unit 1}

Structural measurements and microstructural observations were made on cores from Hole U1527A, which include a shape-preferred orientation (SPO) defined by elongate vesicles, bands with different proportions of vesicles, contacts between alteration styles, and fractures. Additionally, Hole U1527A has only a few fractures and no veins, faults, or crystal-plastic deformation. All observations and measurements were recorded in the DESClogik macroscopic worksheets. All measurements were made on Sections 376U1527A-5R-1 and 6R-1. Sections 4R-CC and 9R-CC are rubble and are inferred to be drilling induced and not indicative of fault zones.

\section{Volcanic structures}

Four within-unit structures were measured, including either vesicle SPO or bands with different proportions of vesicles. Vesicledefined SPO ranges from subhorizontal $\left(0^{\circ}-10^{\circ}\right.$ dip $)$ to inclined $\left(40^{\circ}-50^{\circ} \mathrm{dip}\right)$. Subhorizontal, elongated vesicles are present in intervals 376-U1527A-5R-1, 0-31 cm (38.8-39.17 mbsf) and 6R-1, 86$114 \mathrm{~cm}$ (49.36-49.64 mbsf). Inclined, elongated vesicles occur over intervals 6R-1, 20-42 cm (48.7-48.92 mbsf) and 6R-1, 62-86 cm (49.12-49.36 mbsf). Elongated vesicles over the $20-42 \mathrm{~cm}$ interval are curviplanar and range in dip from subhorizontal to inclined. In thin section, represented by interval 6R-1, 23-25 cm (TS 2; 48.73$48.75 \mathrm{mbsf}$ ), vesicles are subhorizontal. By contrast, plagioclase and clinopyroxene microlites and phenocrysts are isotropic. Vesicles in interval 6R-1, 35-95 cm (48.85-49.45 mbsf) are aligned and contained in bands of differing vesicularity that dip $50^{\circ}$. Bands are a few centimeters thick and have slightly different color.

Because the inclination of the paleomagnetic remanent magnetic vector is consistent over the above intervals (see Paleomagne- tism), the vesicle orientation is considered primary and the differences in orientation are a result of lava flow rather than block rotation.

\section{Alteration contacts and veins}

The orientation of a lower contact of an alteration type was measured. This contact occurs in interval 376-U1527A-5R-1, 13$15.5 \mathrm{~cm}(38.93-38.955 \mathrm{mbsf})$ and is characterized by zeolite-filled vesicles (see Alteration). The contact is planar to curviplanar and has a $45^{\circ}$ dip. This assessment was confirmed by microscopic observations on interval 5R-1, 13-15 cm (TS 1; 38.93-38.95 mbsf), which has a planar to curviplanar contact between the slightly altered zone and fresher lava.

\section{Brittle structures}

Brittle deformation is limited to intervals with discrete fractures. Five fractures were measured on Sections 376-U1527A-5R-1 and $6 \mathrm{R}-1$. The fractures are mostly planar, with one irregular, and they range in dip from steep $\left(87^{\circ}\right)$ to moderate $\left(37^{\circ}\right)$ with an average of $65^{\circ}$. Almost all of the fractures are fully to partially covered by a film of orange to brown alteration phases.

\section{Hole U1527C: Igneous Units 1 and 2}

Structural measurements and microstructural observations were made on Hole U1527C cores, including alteration contacts, faults and shears, alteration veins, and fractures; all were recorded in the DESClogik macroscopic worksheets. Igneous contacts were inferred by the Igneous Petrology and Volcanology team, but none was actually recovered. Volcanic clasts in Igneous Unit 2 (see Igneous petrology and volcanology) have vesicles and microlites with SPO. Because of the random orientation of clasts in lapilli-tuff and lapillistone, it was not possible to record meaningful orientation of 
Figure F27. Dip and density, Hole U1527C. There is casing above $100 \mathrm{mbsf}$. Inset: histogram of fracture and alteration vein dips in $10^{\circ}$ bins. Black curve is the expected distribution of a random set of dips sampled by a vertical borehole (see Structural geology in the Expedition 376 methods chapter [de Ronde et al., 2019a]). Fracture density is based on a scale of 0 to 3; vein density is based on a scale of 0 to 5 (for definition of fracture and vein density, see Structural geology in the Expedition 376 methods chapter [de Ronde et al., 2019a]).

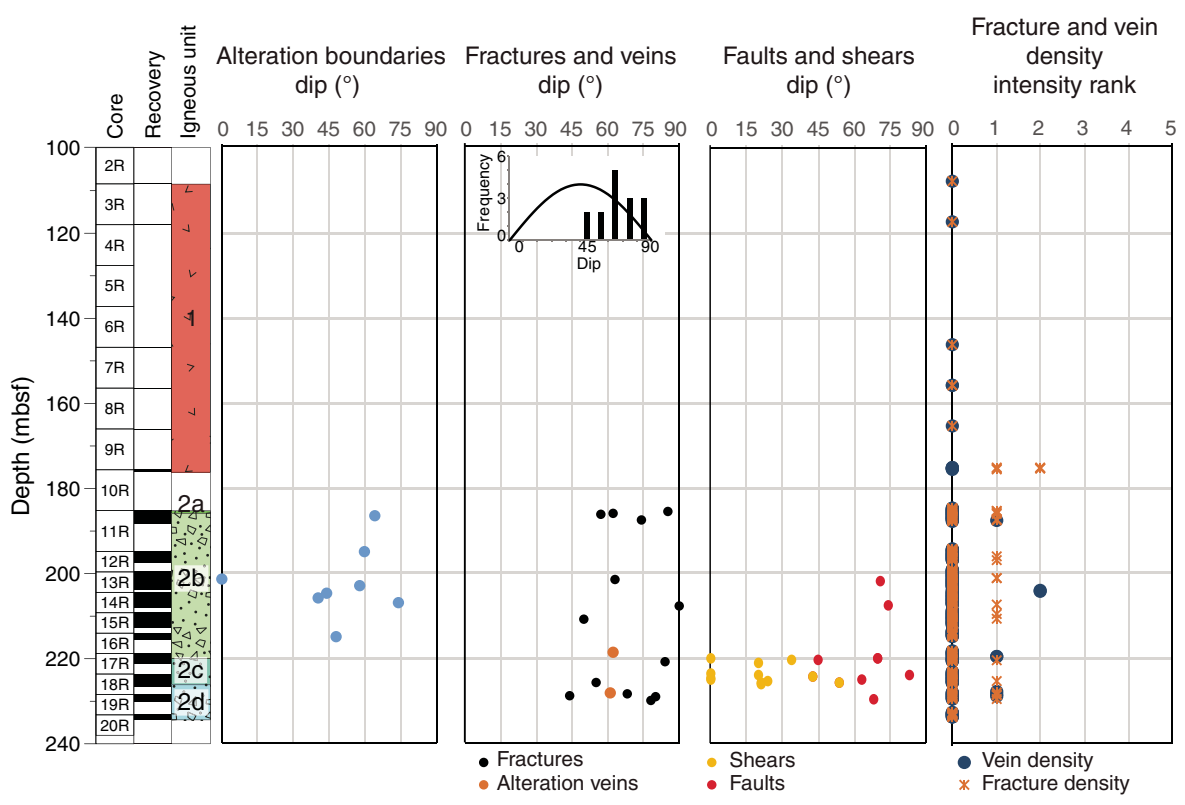

volcanic fabrics, so they were not measured. Sections 376-U1527C3R-1, 7R-1, 8R-1, 9R-1, and 10R-1 are mostly rubble and unoriented pieces interpreted to be due to drilling disturbances rather than the presence of faults.

\section{Alteration contacts and veins}

Only two measurable alteration veins were identified by the Alteration team in Igneous Unit 2 and Alteration Subtype IIa. Veins occur in interval 376-U1527C-17R-1, $130 \mathrm{~cm}$ (218.8 mbsf), and 19R-1, $102 \mathrm{~cm}$ (228.4 mbsf). Both veins are no more than $1 \mathrm{~mm}$ thick, branching and irregular, and filled with silica and pyrite (see Alteration; see also the Alteration tab in DESClogik Macroscopic workbook in DESC_WKB in Supplementary material). Both of the veins have a dip of $\sim 60^{\circ}$, which is very similar to measured open fractures (see below).

Alteration contacts are sharp, cross both matrix and volcanic clasts, are planar to curviplanar, and exhibit a color change from green-gray (Alteration Subtype IIa) to brown (Alteration Subtype IIb) (see Alteration). Eight alteration contacts were measurable; dip varies from horizontal to $74^{\circ}$ with an average and median of $49^{\circ}$ (Figure F27).

\section{Brittle structures}

Fractures were observed only in Igneous Unit 2 and across Alteration Subtypes Ib, IIa, IIb, and Alteration Type III. Fracture and vein density is quite low, never reaching more than five veins or fractures per $10 \mathrm{~cm}$ (Figure F27). In total, 15 fractures were identified, of which 13 were measureable. Fracture dip is steep, ranging from $44^{\circ}$ to $90^{\circ}$ with an average of $68^{\circ}$ (standard deviation $=14.6^{\circ}$ ) (Figure F27). Fractures are mostly irregular, but a few are planar. The majority of fractures are associated with orange-brown alteration, and they sometimes have an alteration halo.
Thirteen fault zones were identified based on discrete, foliated, fine-grained zones, nine of which were measureable. All faults occur in Igneous Unit 2 and across Alteration Subtypes IIa, IIb, and Alteration Type III. Fault dip ranges from $45^{\circ}$ to $83^{\circ}$ with an average of $66^{\circ}$ and a standard deviation of $11.2^{\circ}$ (Figure F27). Fault zones are usually $2 \mathrm{~cm}$ and no more than $4 \mathrm{~cm}$ wide. Each fault zone consists either of a well-defined fault breccia or a cataclasite. Both fault breccias and cataclasites have a low percentage of clasts, which are rounded and matrix supported (Figure F28). Fault texture is best exemplified microscopically in intervals 376-U1527C-18R-1, 58-60 cm (TS 20; 224.18-224.2 mbsf), and 20R-1, 29-31 cm (TS 23; 233.49-233.51 mbsf), although faults are also present in intervals 13R-2, 105-107 cm (TS 10; 202.15-202.17 mbsf), and 14R-3, 102$104 \mathrm{~cm}$ (TS 13; 207.58-207.6 mbsf). The sense of shear on all faults, where determined, is normal. The majority of faults occur deeper in the hole and seem to cluster within Igneous Subunit 2c (see Igneous petrology and volcanology). In Subunit 2c, what look to be shallowly inclined crystal-plastic fabrics have dips from $0^{\circ}$ to $45^{\circ}$ (average of $22^{\circ}$ ), as exemplified in Sections 18R-1 and 18R-2 (Figure F28B). Fabrics are defined by white ribbons that are deflected around larger volcanic clasts. Some of the volcanic clasts have tapered edges, one of which is transposed into a fault zone (Figure F28B). The high aspect ratio of the white ribbons and the tapered edges of volcanic clasts support the presence of crystal-plastic deformation. One potential cause of a shallowly dipping fabric is collapse during cooling and perhaps an increase in lithostatic load from burial by another eruption. This fabric is cut by the higher angle faults.

Fault microstructures are consistent with cataclasis, defined by more than $70 \%$ matrix and rounded to subrounded clasts (Figure F29). The most intense zones are the most fine grained and tend to have a clay-rich matrix. Cataclastic zones are typically only a few 
Figure F28. Faults, Hole U1527C. A. Cataclastic zone next to undeformed volcanic clast in wall rock (black clast). B. Shallowly dipping shears defined by elongate, high aspect ratio, and white ribbons that deflect around larger volcanic clasts (yellow arrows). Some larger volcanic clasts have tapered tails, one of which is transposed into crosscutting fault (white arrow). Fault is cataclastic and is very fine grained in contact with larger volcanic clast, determined in thin section. Fabric is transposed on either side of the fault zone, indicating a normal sense of shear. C. Fault breccia at the boundary between Alteration Subtypes Ila (green) and Ilb (brown).

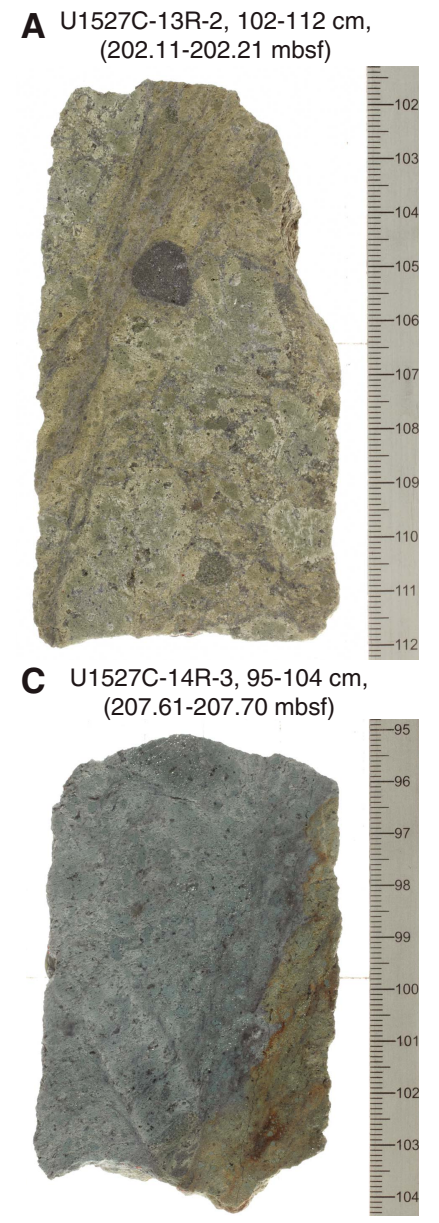

$$
\begin{gathered}
\text { B } \quad \text { 1527C-18R-1, } 52-77 \mathrm{~cm} \text {, } \\
(224.38-224.64 \mathrm{mbsf})
\end{gathered}
$$

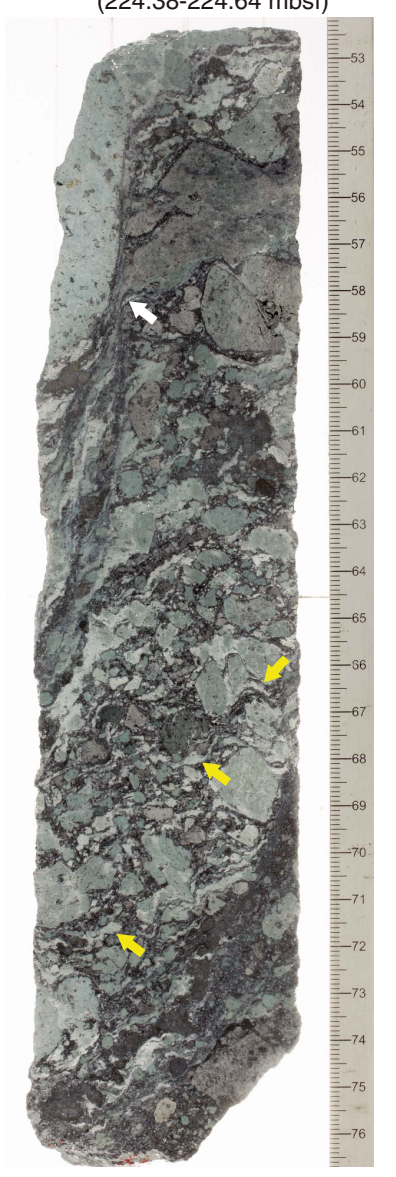

millimeters thick and are surrounded by fault breccias (Figure F29B). Fault breccias are also only a few millimeters thick but contain more clasts (Figure F29B), including fragments of plagioclase and volcanic clasts.

\section{Summary}

Site U1527 is characterized by moderate to steeply dipping alteration contacts, fractures, and faults in addition to shallowly dipping shears and relatively few veins. Vesicle and plagioclase phenocryst and/or microlite SPOs are indicative of primary volcanic structures. Fractures are almost always associated with oxidation alteration (brown color), which may indicate that they formed relatively late and acted as pathways for ambient seawater ingress. Faults tend to be thin, discrete, high-angle, normal sense cataclasites to fault breccias. The overall lack of veins and indications of late fractures suggest that alteration is not structurally controlled and may instead be due to pervasive, hydrothermal flow.
Figure F29. Fault zones, Hole U1527C. A. Cataclastic zone bounded by volcanic clast. Upcore is to the top of the image (black arrow). B. Cataclastic zone bounded by fault breccia. Cataclastic zone has fine-grained, brown clay; fault breccia has black, altered volcanic clasts. Piece is unoriented.
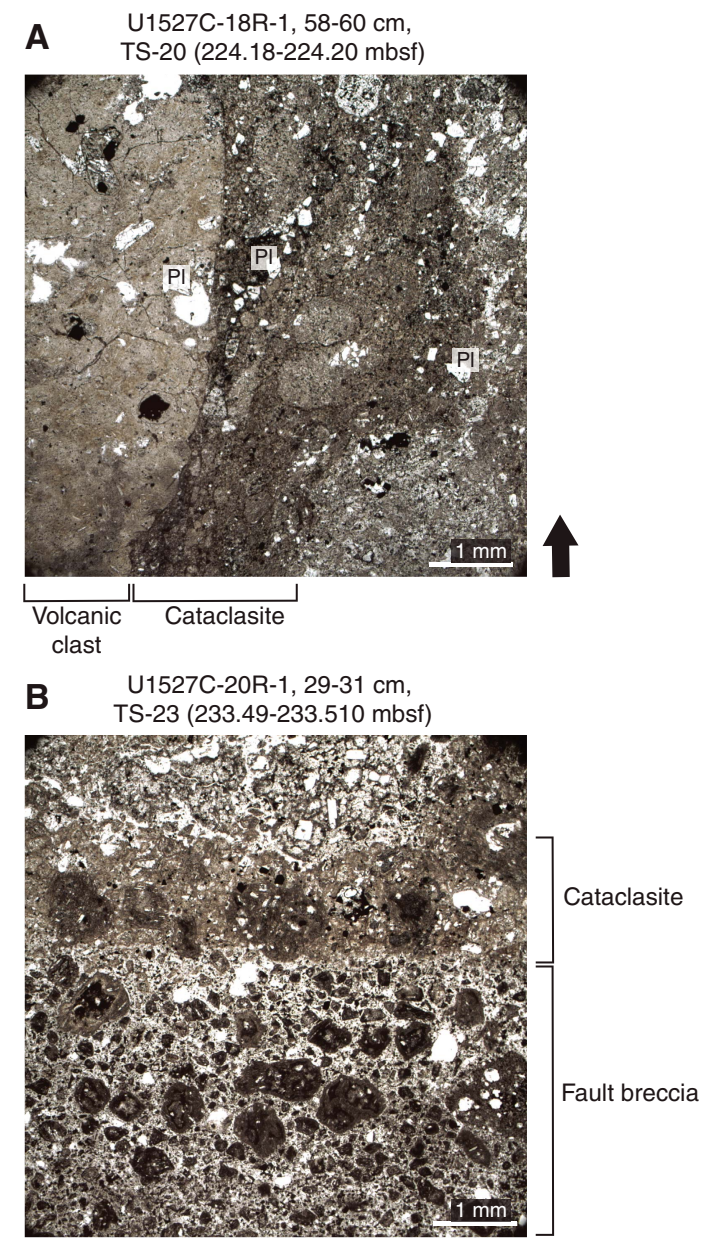

\section{Geochemistry Hard rock geochemistry}

A set of lithologic samples of varying types from Site U1527 was chosen for shipboard geochemical analysis of their major and trace element compositions. Sample selection was based on both lithostratigraphic position and alteration extent (see Igneous petrology and volcanology and Alteration for characterization of the igneous units and alteration types). In total, 46 samples were analyzed, covering the entire depth range from 38.85 mbsf (Sample 376U1528A-5R-1, 5-7 cm) to 234.33 mbsf (Sample 20R-1, 113-114 $\mathrm{cm})$. These samples represent the dominant lithologies recovered from Holes U1527A and U1527C and are briefly described by the following characteristics:

- Seven unaltered dacites (Holes U1527A and U1527C, Igneous Unit 1);

- One fresh lapilli-tuff with a brown matrix (Hole U1527C, Igneous Subunit 2a);

- Twenty-five altered, matrix-supported lapilli-tuff and tuff-breccias with light green to greenish gray altered volcanic clasts (Hole U1527C, Igneous Subunit 2b); 
- Six altered, clast-supported lapillistones with bluish gray altered volcanic clasts (Hole U1527C, Igneous Subunit 2c). In addition, six samples were prepared by separating clast materials from Sample 376-U1527C-18R-2, 36-38 cm. These subsamples were separated by crushing the sample into millimeter-size grains and picking under binocular microscope according to their color (from white-green to dark gray-green);

- Five altered lapilli-tuff and tuff-breccias with bluish gray to greenish gray, poorly sorted volcanic clasts (Hole U1527C, Igneous Subunit 2d); and

- Two volcanic samples recovered from the BHA in Hole U1527C consisting almost exclusively of ash- to medium lapilli-sized scoria (Samples 376-U1527C-BHA-P, glistening pumice, and 376-U1527C-BHA-S, darker scoria).

Major and trace element compositions of 16 powders were analyzed by both inductively coupled plasma-atomic emission spectroscopy (ICP-AES) and pXRF (Tables T4, T5). Major element oxide concentrations were determined by ICP-AES, and total iron was recalculated as $\mathrm{Fe}_{2} \mathrm{O}_{3}$. In addition, 12 other samples were analyzed exclusively by ICP-AES and another 13 only by pXRF. Mafic, intermediate, and silicic calibrated rock standards were analyzed in replicate as unknowns to determine precision and accuracy of both methods (see Geochemistry in the Expedition 376 methods chapter [de Ronde et al., 2019a] for information on analytical procedures, instrumentation, and data quality assessment). A comparison of ICP-AES and pXRF results for elements that were measured using both methods is shown in Figure F30. Reasonable agreement

Table T4. Major and trace element abundances determined by portable $X-$ ray fluorescence (pXRF), Holes U1527A and U1527C, Expedition 376. Download table in CSV format.

Table T5. Major and trace element abundances determined by inductively coupled plasma-atomic emission spectroscopy (ICP-AES), Holes U1527A and U1527C, Expedition 376. Download table in CSV format.

Figure F30. Comparison of pXRF and ICP-AES results for major and trace elements obtained on the same sample powder for (top) unaltered dacite (Igneous Unit 1) in Hole U1527A and (bottom) altered breccia (Igneous Unit 2) in Hole U1527C. Results show stronger discrepancies in altered samples (Unit 2, Hole U1527C), with significant differences for major element Mg and trace element $\mathrm{Zn}$.
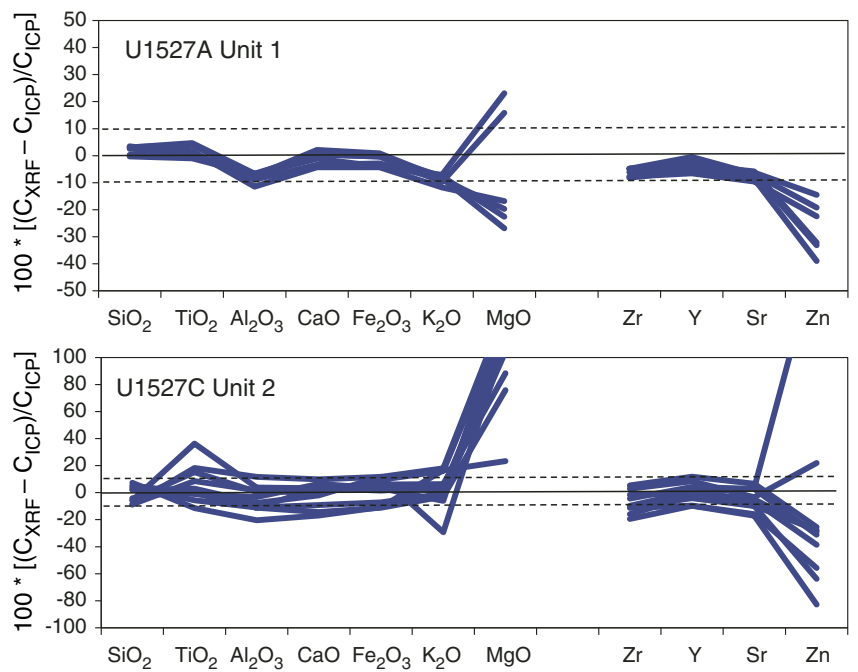

between ICP-AES and pXRF data (i.e., a relative difference of $\pm 10 \%$ ) was observed for major and minor elements for unaltered dacite (Hole U1527A, Igneous Unit 1), except for $\mathrm{Mg}$ and $\mathrm{Zn}$ and to a lesser degree $\mathrm{Al}, \mathrm{K}$, and $\mathrm{Sr}$, which show $>10 \%$ variability between methods for some individual analyses. By contrast, relative differences of $>10 \%$ between ICP-AES and pXRF results were commonly observed for the altered volcaniclastics (Hole U1527C, Igneous Unit 2) with relatively large deviations for most elements except $\mathrm{Si}, \mathrm{Ca}$, $\mathrm{Fe}, \mathrm{Zr}$, and $\mathrm{Y}$, which are in good agreement. Both measurements using a similar set of georeference materials. The reasons for such pronounced differences between ICP-AES and pXRF results for altered volcanics are probably related to calibration issues for $\mathrm{MgO}$ and higher detection limits for $\mathrm{P}_{2} \mathrm{O}_{5}, \mathrm{Cu}$, and $\mathrm{Zn}$ using pXRF.

\section{Igneous geochemistry}

Unaltered volcanic rocks from Holes U1527A and U1527C (Igneous Unit 1) are dacites with $\mathrm{SiO}_{2}$ ranging from 63.10 to $66.20 \mathrm{wt} \%$ and $\mathrm{Na}_{2} \mathrm{O}+\mathrm{K}_{2} \mathrm{O}$ ranging from 6.92 to 7.40 wt\% (Figure F31; Table

Figure F31. Major element Harker diagrams, Holes U1527A and U1527C. A. Total alkali $\left(\mathrm{Na}_{2} \mathrm{O}+\mathrm{K}_{2} \mathrm{O}\right)$ vs. $\mathrm{SiO}_{2}$. B. $\mathrm{CaO}$ vs. $\mathrm{SiO}_{2} \cdot \mathrm{C} . \mathrm{Al}_{2} \mathrm{O}_{3}$ vs. $\mathrm{SiO}_{2}$. D. $\mathrm{TiO}_{2}$ vs. $\mathrm{SiO}_{2}$. E. MgO vs. $\mathrm{SiO}_{2}$. Data are reported for unaltered dacites (Igneous Unit 1 , Holes U1527A and U1527C) and altered volcaniclastic breccia (Igneous Unit 2, Hole U1527C) and comparisons with (1) dacitic to rhyolitic glasses and whole rock from Brothers volcano reported in previous studies (e.g., Haase et al., 2006; Wright and Gamble, 1999; Timm et al., 2012) and (2) subaerial lavas recovered along the Kermadec arc $\left(25^{\circ} \mathrm{S}\right.$ to $37^{\circ} \mathrm{S}$ ) (data compiled from the GEOROC geochemical database, http://georoc.mpch-mainz.gwdg.de/georoc).
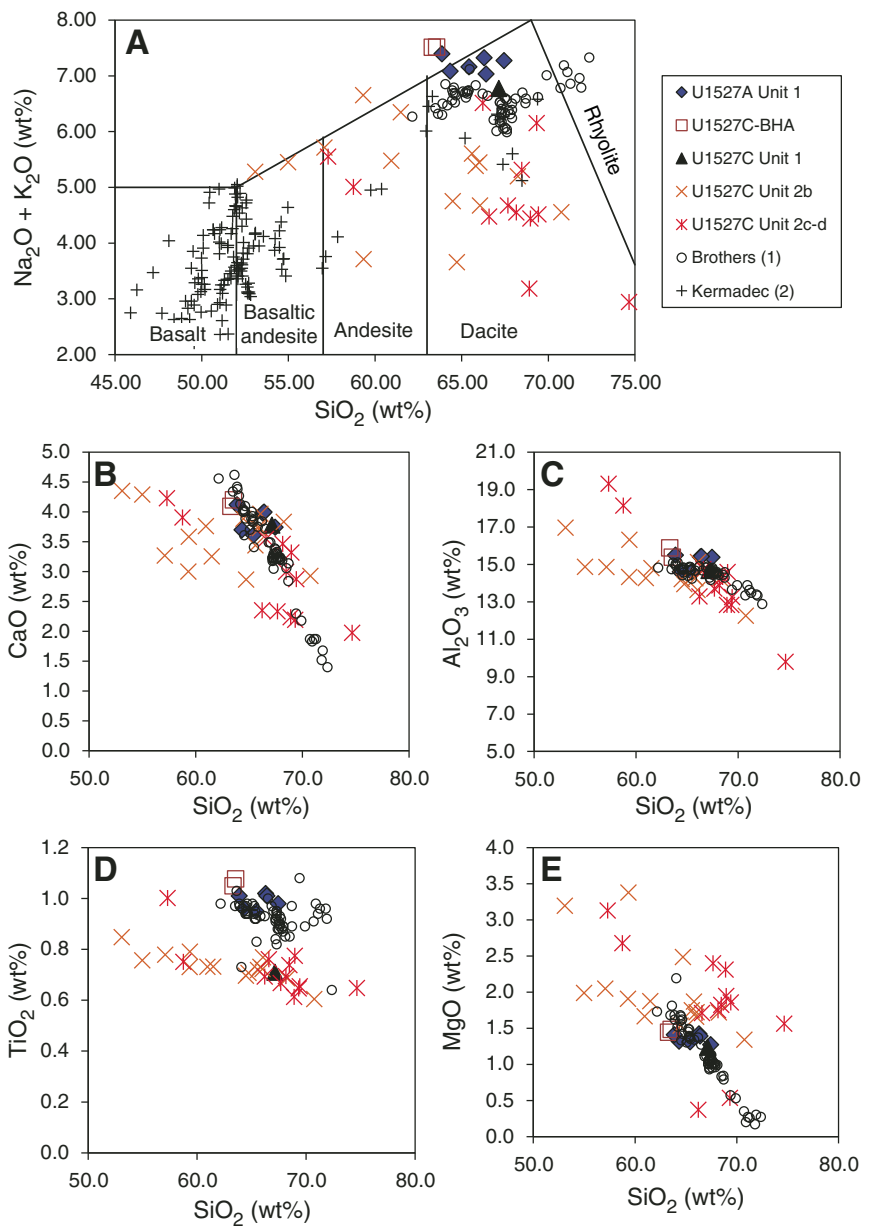
were performed on homogenized rock powder and were calibrated 
T5). Glassy and vesicular volcanic material recovered from the BHA in Hole U1527C consists almost exclusively of scoria and pumice and is compositionally similar to dacitic Unit 1, although its depth of recovery is unknown. Hence, fresh dacites recovered from Site U1527 display, as a whole, very limited major compositional ranges and are essentially similar to the least evolved dacites previously reported from Brothers volcano (Wright and Gamble, 1999; Haase et al., 2006; Timm et al., 2012; Graham et al., 2008) (Figure F31).

Total sulfur contents of unaltered volcanic rocks from Holes U1527A and U1527C range from 150 to $400 \mu \mathrm{g} / \mathrm{g}$, significantly higher values than sulfur contents measured in dacitic glasses (maximum $=180 \mu \mathrm{g} / \mathrm{g}$ ) previously recovered from dredged samples at Brothers volcano (Haase et al., 2006). Although it is possible that recovered lavas at Site U1527 did not degas extensively and therefore retained much of their volatile inventory, the observed sulfur enrichment is probably related to incipient alteration of the volcanic groundmass. In particular, petrographic observations suggest that trace pyrite is present in proximity to the palagonite-rich zone, suggesting a secondary (i.e., alteration) origin of sulfur enrichment in dacites from Igneous Unit 1.

Most of the moderately to highly altered volcaniclastic rocks recovered from Hole U1527C (Igneous Unit 2) also share a similar dacitic composition. Considering that $\mathrm{SiO}_{2}$ and $\mathrm{CaO}$ are more resistant to mobilization by hydrothermal fluids than $\mathrm{K}_{2} \mathrm{O}$ is (see Alteration geochemistry), lapilli-tuff and tuff-breccia show a $\mathrm{SiO}_{2}$ versus $\mathrm{CaO}$ relationship similar to dacites and rhyolites previously reported from Brothers volcano (Wright and Gamble, 1999; Haase et al., 2006; Timm et al., 2012) (Figure F31). Compositional variations in $\mathrm{Al}_{2} \mathrm{O}_{3}$ and $\mathrm{SiO}_{2}$ display limited variability, suggesting that the effect of plagioclase accumulation on bulk-rock chemistry of the plagioclase porphyritic and glomeroporphyritic dacite from Igneous Units 1 and 2 is quite limited (Table T5).
To determine whether there are differences in the composition of primitive magmas unaffected by crystal fractionation and mineral accumulation, correlations between fluid-immobile elements $\mathrm{Zr}$, Y, and Ti were examined (Figure F32). Notably, Igneous Unit 1 in Hole U1527A and combined Igneous Units 1 and 2 in Hole U1527C show two separate trends with different $\mathrm{Zr} / \mathrm{Y}$ and $\mathrm{Zr} / \mathrm{Ti}$ values. The two scoria samples collected from the BHA in Hole U1527C (Figure F32) have a composition similar to that of Unit 1 in Hole U1527A. These results may indicate that despite the petrographic differences between Units 1 and 2, unaltered plagioclase phyric dacite lava (108.4-176.2 mbsf) and highly altered volcaniclastics (185.2-234.4 mbsf) are derived from the same parental magma. Conversely, the unaltered dacites from Hole U1527A (29.1-67.8 mbsf) may be derived from a different magma source (e.g., different degrees of melting) than unaltered dacite in Unit 1 in Hole U1527C.

\section{Volatile geochemistry}

At Site U1527, all samples were analyzed for TC and total inorganic carbon (TIC). Total organic carbon (TOC) for each sample was then calculated by difference: TOC $=$ TC - TIC. Measured data and associated uncertainties for loss on ignition (LOI), TIC, TC, total nitrogen (TN), and total sulfur analysis are reported in Table T6, along with TOC abundances estimated from TC and TIC abundance. Downhole variation in total sulfur abundance, total pyrite volume percent (estimated macroscopically; see Alteration), TC and TIC abundance, and iron oxyhydroxide abundance (estimated macroscopically) are presented in Figure F33. The majority of samples recovered from Holes U1527A and U1527C contain $<300 \mu \mathrm{g} / \mathrm{g} \mathrm{TC}$, as determined by elemental analyzer (TC detection limit $=50 \mu \mathrm{g} / \mathrm{g}$ ) (Table T6). Coulometry was used to determine TIC abundance in all samples collected for ICP-AES analysis (Table T6). This data set also includes four samples collected for microbiological analysis.

Figure F32. Zr/Ti and Y/Ti for unaltered dacites (Igneous Unit 1, Holes U1527A and U1527C; average = blue lines) and altered volcaniclastic breccia (Igneous Unit 2, Hole U1527C; average = green lines). Dashed lines $=1 \sigma$ from average values. The difference in $\mathrm{Zr} / \mathrm{Ti}$ and $\mathrm{Y} / \mathrm{Ti}$ may indicate different parental magmas for the two units. The two shallowest samples (U1527C-BHA) correspond to relatively unaltered volcanic material recovered from the BHA in Hole U1527C (scoria and pumice) and are geochemically similar to Unit 1 dacites from Hole U1527A. Downhole variations in $\mathrm{Al}_{2} \mathrm{O}_{3}$ and $\mathrm{Fe}_{2} \mathrm{O}_{3}$ are also shown for comparison.

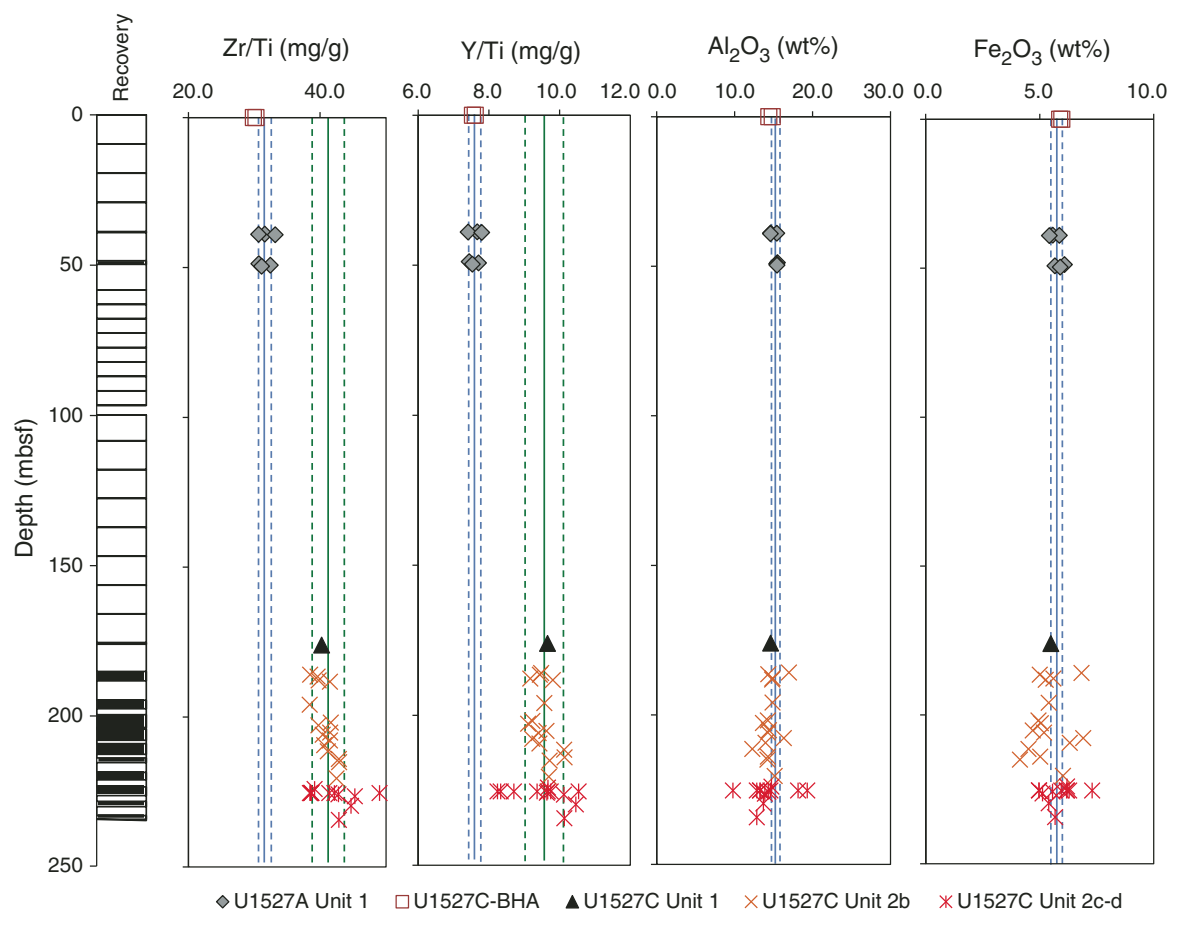


Table T6. Total carbon (TC), total sulfur (TS), and total nitrogen (TN) measured by elemental analyzer; total inorganic compound (TIC) measured by coulometry; and total volatiles measured by loss on ignition (LOI), Holes U1527A and U1527C, Expedition 376. Download table in CSV format.

Figure F33. Downhole variations of total sulfur (TS), TC, and TIC compared with macroscopic estimates of pyrite and iron oxyhydroxide abundances, Holes U1527A and U1527C (see Alteration).

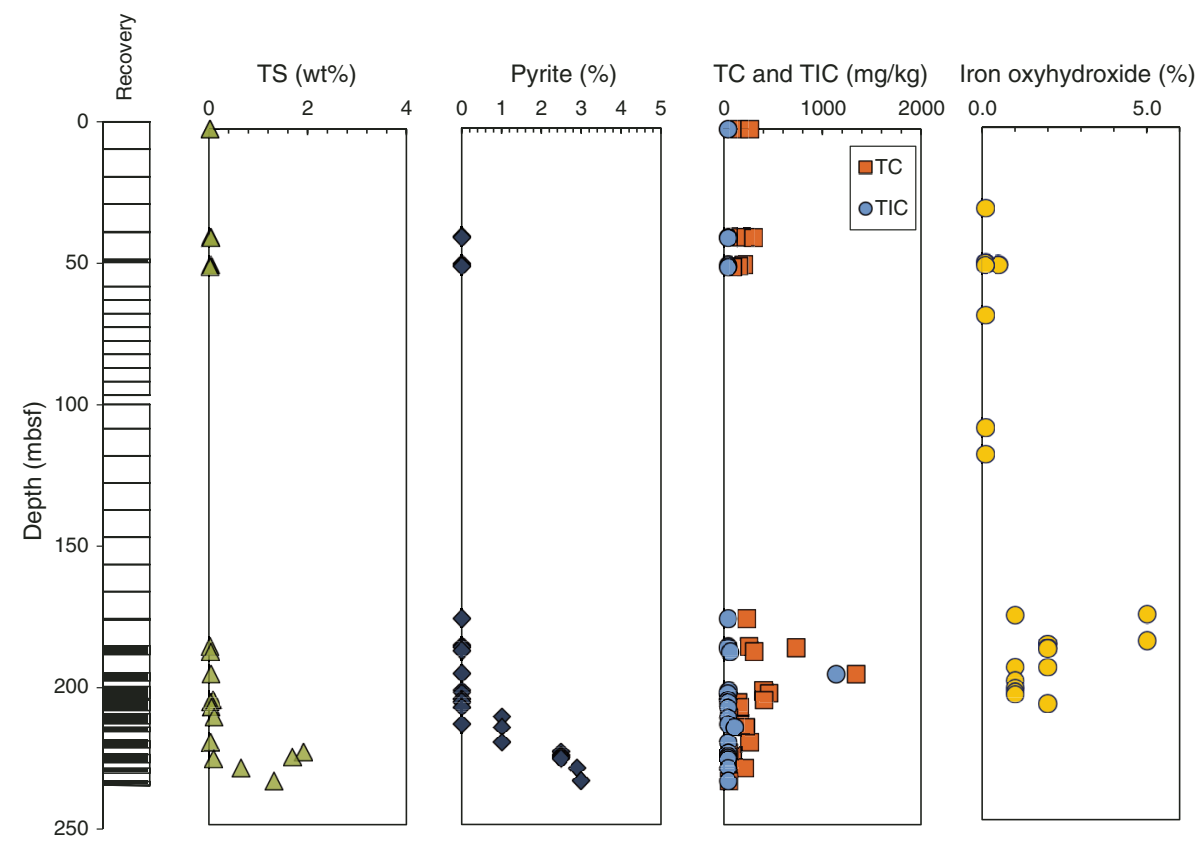

When measurement uncertainty is taken into account, most samples contain inorganic carbon (TIC) abundances that fall below the detection limit. Only one sample with high TIC $(1139 \pm 20 \mu \mathrm{g} / \mathrm{g})$ suggests the presence of significant amounts of carbonates. However, the examination of thin sections and XRD patterns of several samples from the same depth interval did not show any occurrence of carbonates. Samples with relatively high TOC contents $(>400$ $\mu \mathrm{g} / \mathrm{g}$, or $0.04 \mathrm{wt} \%$ ) occur only in the shallower units (185-205 mbsf) and generally correspond to the least altered lithologies (see Alteration for description of alteration style and extent). Most samples from deeper intervals (205-235 mbsf) contain TOC contents below the detection limit.

In comparison, oceanic gabbros and serpentinized lithologies from the Iberian margin of the Atlantic Ocean contain 0.008-0.101 wt\% TOC (Delacour et al., 2008), whereas basalts on the flanks of a mid-oceanic ridge (Juan de Fuca Ridge) typically contain $0.010-$ 0.080 wt\% TOC (Lever et al., 2013). Results from Site U1527 are within these ranges. Palagonitic glass alteration, which consists of a mixture of clay minerals, oxides, and zeolites, can contain significantly higher weight percent levels of TOC than those observed for Brothers volcano rocks (e.g., 0.4-1.5 wt\%) (Kruber et al., 2008). TOC in subseafloor settings such as Site U1527 could originate from either seawater-derived circulating hydrothermal fluids and/or relict or extant subseafloor microbial communities (Delacour et al., 2008; Klein et al., 2015).

In summary, recovered rocks from Site U1527 show very limited TOC enrichment, particularly in the deeper Igneous Unit 2, which is consistent with a higher extent of hydrothermal alteration and virtually no TIC that can be related to carbonate, as in the observed mineralogy.

\section{Alteration geochemistry}

Igneous Unit 2 consists of hydrothermally altered lapilli-tuff and tuff-breccia and is divided into four subunits $(2 a-2 d)$ based on changes in alteration type, matrix-to-clast ratio, and color (see Igneous petrology and volcanology). Three distinct alteration types (I-III) and four subtypes (Ia, Ib, IIa, and IIb) were identified at Site U1527 (see Alteration). Alteration Subtypes Ia and Ib occur within Igneous Unit 1 and Subunit 2a, and Alteration Types II and III occur in Igneous Subunits 2a-2d. Only incipient alteration (Subtype Ia), if any, is present in material recovered from Hole U1527A and the upper part of Hole U1527C (99.90-185.20 mbsf). Hence, major and trace element compositions of these lavas may be used to estimate the primary composition of the altered volcanics recovered in Unit 2, which underlies Unit 1.

The degree of hydrothermal alteration increases downhole, corresponding to an increase in silicification and a greater abundance of secondary sulfides (see Alteration). Downhole variations of key geochemical parameters are generally consistent with petrographic observations. Highly altered volcaniclastics from Igneous Subunits 2c and $2 \mathrm{~d}$ have high total sulfur contents $(\leq 1.9 \mathrm{wt} \%)$ resulting from the increased abundance of pyrite associated with Alteration Type III (Figure F33). The higher degree of alteration encountered in Subunits $2 \mathrm{~b}-2 \mathrm{~d}$ also corresponds to a significant increase in $\mathrm{Mg}$ and $\mathrm{Si}$ contents (i.e., relative to unaltered dacite) (Figure F34), consistent with the formation of chlorite and silica (e.g., quartz, opal) associated with Alteration Subtypes IIa and IIb and Alteration Type III. By contrast, downhole variations in $\mathrm{K}_{2} \mathrm{O}$ show much more variability with both enrichment and depletion across Subunits 2b-2d (Figure F34).

The highest $\mathrm{Ba}$ and $\mathrm{K}_{2} \mathrm{O}$ values were measured in Sample 376U1527C-18R-2, 33-34 cm (Table T5), and correspond to a volcanic 
Figure F34. Downhole variations of $\mathrm{K}_{2} \mathrm{O}, \mathrm{MgO}$, and $\mathrm{SiO}_{2}$ compared with macroscopic estimate of alteration intensity, Holes U1527A and U1527C (see Alteration). Solid vertical lines $=$ average values of shallower, unaltered Igneous Unit 1, Hole U1527A. Dashed lines $=1 \sigma$ from average values. The two shallowest samples (U1527C-BHA) correspond to from relatively unaltered volcanic material recovered from the BHA in Hole U1527C.

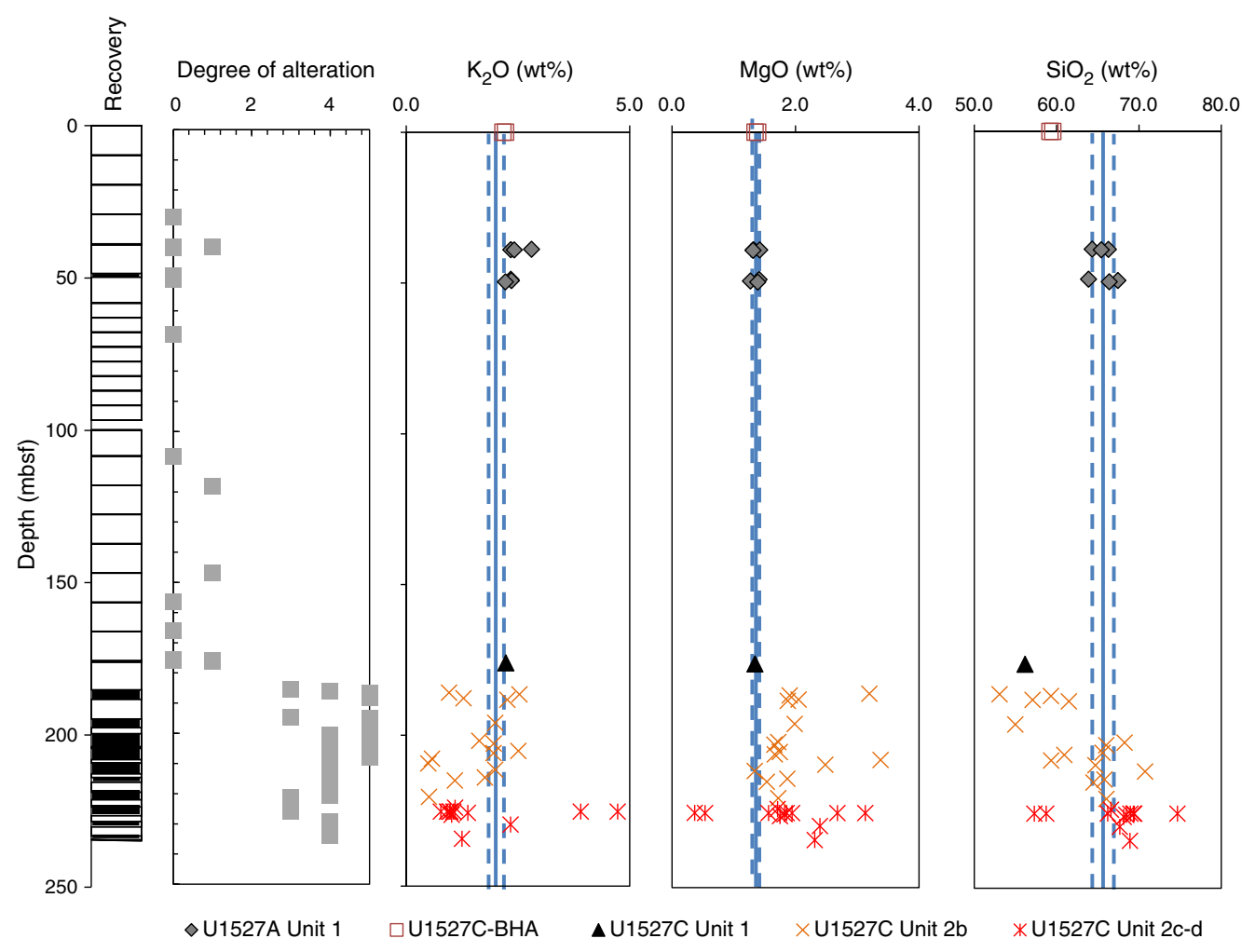

clast separated from a tuff-breccia at 225.32 mbsf. Four main clast types were distinguished based on color: green, white, gray, and dark gray to black. Although this sample was initially described as a dark gray clast, geochemical data are more consistent with the green clast type, which is characterized by intense alteration and illite (i.e., K-rich clay material). To further test the geochemical variability of the different clast types, potentially related to variability in the protoliths and/or alteration processes, six clasts were separated from Sample 376-U1527C-18R-2, 36-38 cm (Subsamples A to F). Results show that light green to dark green clasts have a large range of $\mathrm{K}_{2} \mathrm{O}(0.91-3.9 \mathrm{wt} \%), \mathrm{MgO}(0.54-3.13 \mathrm{wt} \%)$, total sulfur $(0.35-$ 3.99 wt\%), and $\mathrm{Ba}(781-6428 \mu \mathrm{g} / \mathrm{g}$ ) (Table T5). The dark clasts in particular show the highest enrichment in $\mathrm{K}_{2} \mathrm{O}$, Ba, and $\mathrm{S}$ and depletion in $\mathrm{MgO}$. The strong relationships between $\mathrm{Ba}$ and $\mathrm{K}_{2} \mathrm{O}$ enrichment in darker clasts are well supported by the strong correlation between $\mathrm{Ba}$ and $\mathrm{K}_{2} \mathrm{O}$ in Igneous Subunit 2c (Figure F35), yielding $\mathrm{Ba} / \mathrm{K} \approx 0.187 \mathrm{~g} / \mathrm{g} . \mathrm{SiO}_{2}$ contents are also higher in the dark clasts, suggesting more intense silicification (Table T5). Despite the important geochemical differences, the clast types have similar $\mathrm{Zr} / \mathrm{Ti}$ to Igneous Units 1 and 2 in Hole U1527C, suggesting a common protolith.

\section{Determination of enrichment/depletion factors}

To assess the bulk geochemical exchange during alteration, average compositions of altered breccia were compared with those of the least altered samples (Figure F36). In this calculation, samples were grouped according to their lithostratigraphic positions and alteration types. This approach resulted in the determination of average compositions using the following:
Figure F35. Ba vs. $\mathrm{K}_{2} \mathrm{O}$ for unaltered dacites (Igneous Unit 1; Holes U1527A and U1527C) and altered breccia (Igneous Unit 2; Hole U1527C). Previously published data from Brothers volcano and Kermadec arc are shown for comparison (data from Haase et al., 2006; Wright and Gamble, 1999; and the GEOROC geochemical database http://georoc.mpch-mainz.gwdg.de/georoc). The correlation between $\mathrm{Ba}$ and $\mathrm{K}_{2} \mathrm{O}$ for unaltered lava from Brothers volcano is consistent with the effect of fractional crystallization (Haase et al., 2006), whereas decreases in both $\mathrm{Ba}$ and $\mathrm{K}_{2} \mathrm{O}$ in altered breccia in Subunit $2 \mathrm{~b}$ are consistent with the mobility of these elements (i.e., depletion, brown arrow) as they leach into hydrothermal fluids during water-rock reactions. By contrast, intensely altered and polymict breccia from Subunits $2 \mathrm{c}$ and $2 \mathrm{~d}$ show significant enrichment in both $\mathrm{Ba}$ and $\mathrm{K}$ (green arrow), consistent with the addition of barite and K-rich clays (e.g., illite or sericite) in the clast matrix. Sample 376-U1527C-18R-2, 33.0-34.0 cm, corresponds to a dark green to dark gray clast that was separated from a breccia displaying Type III alteration.

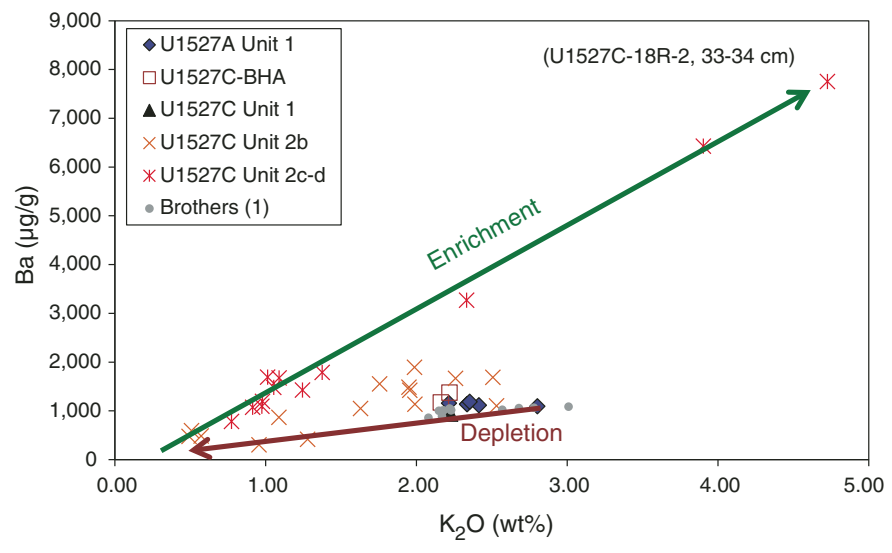


Figure F36. Chemical enrichment factors for major igneous units according to their different alteration types (I-III), Site U1527. Each enrichment curve was obtained by calculating the average composition of each alteration type in each unit and normalizing to the average composition of the least altered dacites recovered in Igneous Unit 1, Hole U1527C (dashed line). TS = total sulfur.

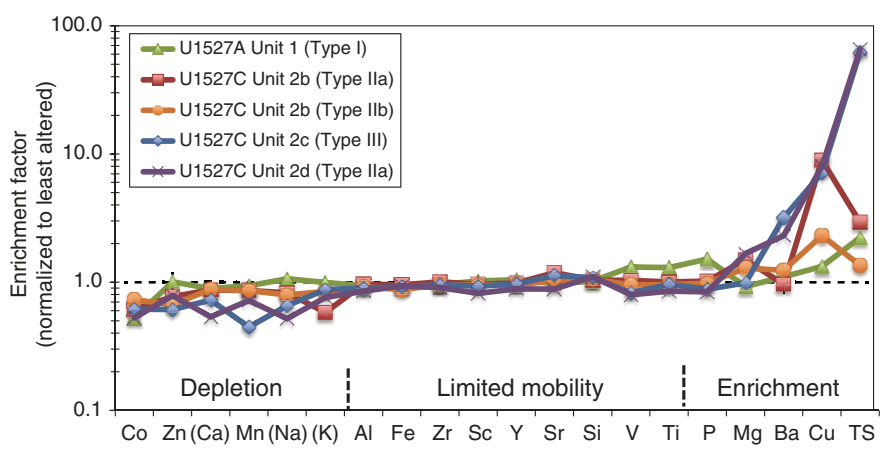

- Eight samples from Igneous Subunit 2b with Alteration Subtype IIa,

- Seven samples from Igneous Subunit 2b with Alteration Subtype IIb,

- Ten samples from Igneous Subunit 2c with Alteration Type III, and

- Two samples from Igneous Subunit 2d with Alteration Subtype IIa.

All average data were normalized to the composition of dacite Sample 376-U1527C-10R-1, 41-42 cm, on the basis that dacitic material from brecciated Igneous Unit 2 may be derived from geochemically similar parental magma sources (see Igneous petrology and volcanology).

In general, geochemical changes between the different alteration types are relatively subtle, with the exception of increasing $\mathrm{Mg}$ near the bottom of the hole. Alteration Subtype IIa and Alteration Type III are characterized by significant enrichment in $\mathrm{Mg}, \mathrm{Cu}$, and total sulfur, as well as depletion in K. Alteration Subtype IIb in Igneous Unit $2 \mathrm{~b}$ is also enriched in $\mathrm{Mg}$, albeit moderately enriched in $\mathrm{Cu}$ and total sulfur, and lacks depletion in $\mathrm{K}$. The most intense alteration type (III) that occurs in Subunit 2c has the strongest enrichment in total sulfur and $\mathrm{Ba}$ and lesser enrichment in $\mathrm{Mg}$. Depletions are observed in $\mathrm{Na}$ and $\mathrm{Ca}$, consistent with more advanced plagioclase alteration, as well as in $\mathrm{Mn}$ and $\mathrm{K}$. Hence, geochemical changes recorded in Hole U1527C are generally consistent with petrographic observations, including the formation of sulfide minerals (primarily pyrite) and the replacement of clast groundmass and breccia matrix with clay minerals (being both $\mathrm{Mg}$ and $\mathrm{K}$ rich).

\section{Synthesis and interpretation}

Based on core descriptions, it is likely that several fragmentation and alteration stages have affected Igneous Unit 2. In particular, clasts in the same sections of the core show different degrees of alteration, as evidenced by their contrasting geochemical compositions. Geochemical studies of altered oceanic crust have shown that alteration of basalt by seawater at low temperature takes up significant amounts of alkalis (Hart and Staudigel, 1982; Kelley et al., 2003). By contrast, high-temperature hydrothermal reactions result in significant release of alkalis, silica, and metals and uptake of $\mathrm{Mg}$ (Humphris and Thompson, 1978; Edmond et al., 1979; Alt, 2003). Hence, $\mathrm{K}$ depletion is a good indicator of high degrees of alteration. The large range of $\mathrm{K}_{2} \mathrm{O}$ contents in Subunits $2 \mathrm{c}$ and $2 \mathrm{~d}$ with both enrichment and depletion relative to unaltered dacite thus reveals a complex history of fragmentation and alteration stages of the primary volcanic material in the breccia, with possibly higher temperature (resulting in $\mathrm{Mg}$ uptake and $\mathrm{K}$ depletion) and lower temperature hydrothermal stages (resulting in $\mathrm{K}$ and possibly $\mathrm{Ba}$ uptake).

$\mathrm{Ba}$ is generally contained in K-rich secondary minerals (i.e., clays) as a trace component; thus, we compared $\mathrm{Ba}$ and $\mathrm{K}_{2} \mathrm{O}$ contents of unaltered dacite and altered breccia from Site U1527. Because of their behavior as incompatible elements, $\mathrm{Ba}$ and $\mathrm{K}$ are highly correlated in lavas generated from one parental magma, as shown by the general trend defined by fresh dacitic glasses from Brothers volcano (Wright and Gamble, 1999; Haase et al., 2006) and other volcanoes along the Kermadec arc (Figure F35). The relationships between $\mathrm{Ba}$ and $\mathrm{K}_{2} \mathrm{O}$ in altered breccia for Igneous Subunit $2 \mathrm{~b}$, however, show a general depletion in both elements in Alteration Subtype IIa, which is best explained by hydrothermal alteration and leaching of fluidmobile elements rather than fractional crystallization. This hypothesis is consistent with petrographic descriptions that detail pervasive alteration of the clast groundmass and matrix, likely composed of volcanic ash or glass fragments. By contrast, highly altered clasts recovered from Igneous Subunit 2c show a strong correlation between $\mathrm{Ba}$ and $\mathrm{K}_{2} \mathrm{O}$ with an overall enrichment reflecting the addition of both $\mathrm{K}$ and $\mathrm{Ba}$ that is probably due to the co-occurrence of secondary clay (i.e., illite) and barite (Figure F35). The occurrence of barite, although not detected by XRD analysis (see Alteration), is supported by the relative enrichment in total sulfur (as much as $4 \mathrm{wt} \%$ ) in Ba-rich samples from Subunit 2c (Table T5).

In summary, volcaniclastic rocks recovered from Hole U1527C do not show strong geochemical changes for a large range of elements despite the substantial extent of alteration and color changes occurring throughout the hole. These elements include relatively fluid immobile $\mathrm{Al}, \mathrm{V}, \mathrm{Zr}, \mathrm{Sc}, \mathrm{Y}$, and $\mathrm{Ti}$ and to a lesser degree $\mathrm{Si}, \mathrm{Sr}$, and $\mathrm{Fe}$, which are elements normally characterized by significant mobility during hydrothermal alteration. These observations are consistent with the hypothesis that the breccias are composed of lava clasts embedded in volcanic ash with the same composition that were then altered by hydrothermal fluids without significant chemical mass transport (see Igneous petrology and volcanology). This hypothesis may also suggest that the temperature of the hydrothermal fluids and/or the time during which Igneous Unit 2 was exposed to hydrothermal fluids was relatively limited, with the exception of Subunit 2d, which is deeper and thus more affected by hydrothermal fluid input. The preliminary geochemical characterization of the clasts in Subunit 2c are also consistent with petrographic studies, suggesting secondary brecciation after alteration of the pyroclastic breccia had already taken place, possibly under lower temperature (or water/rock ratios) conditions. Secondary brecciation may have been caused by movement along the ring faults surrounding the caldera affected by higher temperature fluid circulation.

\section{Headspace analysis of $\mathrm{H}_{2}, \mathrm{CO}$, and $\mathrm{CH}_{4}$}

Dissolved $\mathrm{H}_{2}, \mathrm{CO}, \mathrm{CH}_{4}$, and $\mathrm{C}_{2} \mathrm{H}_{6}$ abundances in pore space were assessed via headspace analysis at six sampled intervals in Hole U1527C between 212.1 and 233.9 mbsf (Table T7; Figure F37). Concentrations of $\mathrm{C}_{2} \mathrm{H}_{6}$ are below the analytical detection limit $(<0.03 \mu \mathrm{mol} / \mathrm{L})$ in all six intervals. In the majority of samples, headspace gas concentrations in general are not greater than those of ambient air. However, several samples (e.g., at 212.1, 226.4, and $233.9 \mathrm{mbsf})$ have elevated concentrations of $\mathrm{H}_{2}(>10 \mu \mathrm{mol} / \mathrm{L})$. These concentrations are unusually high relative to similar analyses per- 
Table T7. Pore space gas concentrations, Hole U1527C. R = rotary core barrel. Download table in CSV format.

\begin{tabular}{lccccc}
\hline Core, section & $\begin{array}{c}\text { Depth } \\
(\mathrm{mbsf})\end{array}$ & $\begin{array}{c}\mathrm{CH}_{4} \\
(\mu \mathrm{mol} / \mathrm{L})\end{array}$ & $\begin{array}{c}\mathrm{C}_{2} \mathrm{H}_{6} \\
(\mu \mathrm{mol} / \mathrm{L})\end{array}$ & $\begin{array}{c}\mathrm{H}_{2} \\
(\mu \mathrm{mol} / \mathrm{L})\end{array}$ & $\begin{array}{c}\mathrm{CO} \\
(\mu \mathrm{mol} / \mathrm{L})\end{array}$ \\
\hline $\begin{array}{l}\text { 376-U1527C- } \\
\text { 15R-2 }\end{array}$ & 212.06 & 2.0 & $<0.03$ & 15 & 1.7 \\
16R-1 & 215.45 & 2.7 & $<0.03$ & 9.2 & 0.54 \\
17R-2 & 220.95 & 1.4 & $<0.03$ & 0.39 & 0.76 \\
18R-2 & 226.44 & 0.92 & $<0.03$ & 13 & 0.65 \\
19R-2 & 230.05 & 1.4 & $<0.03$ & 0.63 & $<0.1$ \\
20R-1 & 233.90 & 1.1 & $<0.03$ & 24 & 2.2 \\
\hline
\end{tabular}

Figure F37. Pore space gas concentrations, Site U1527.

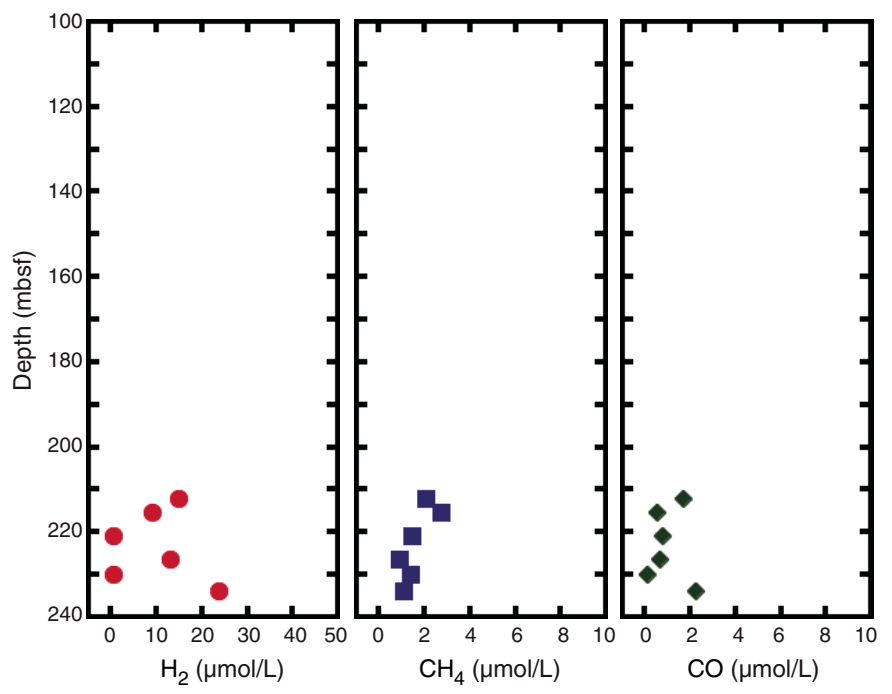

formed in sedimentary and hard rock environments (e.g., Integrated Ocean Drilling Program Expeditions 343 and 366; Chester et al., 2013; Fryer et al., 2018). These $\mathrm{H}_{2}$ concentration anomalies may thus indicate a present-day hydrothermal fluid influence in Hole $\mathrm{U} 1527 \mathrm{C}$. However, a corresponding lack of increased $\mathrm{CO}, \mathrm{CH}_{4}$, and $\mathrm{C}_{2} \mathrm{H}_{6}$ concentrations in the same samples makes a hydrothermal origin of $\mathrm{H}_{2}$ less plausible (Figure F37). Another possible $\mathrm{H}_{2}$ source is mechanochemical $\mathrm{H}_{2}$ production, in which $\mathrm{H}_{2}$ can be generated during RCB coring and/or crushing rock samples prior to headspace sampling (Wakita et al., 1980; Wiersberg and Erzinger, 2008; Hirose et al., 2011).

\section{Paleomagnetism}

Magnetization directions and intensities of oriented pieces larger than $\sim 10 \mathrm{~cm}$ from archive halves from Site U1527 were measured in the cryogenic magnetometer. Any overprint magnetization coming from drilling and coring was removed using in-line alternating field (AF) demagnetization to $70 \mathrm{mT}$. Each archive half was measured by using the magnetometer in continuous sampling mode, and then subsections were analyzed on board at set intervals based on the location of the larger oriented pieces using PuffinPlot v. 1.0.3 (Lurcock and Wilson, 2012). It is important to note that this is a nonstandard measurement, and discontinuous recovery compromises an accurate measurement of the magnetization parameters. For this reason, care should be taken when using the magnetization directions and intensities from the shipboard Labo-
Table T8. Discrete samples, Holes U1527A and U1527C. All samples received anisotropy of magnetic susceptibility and isothermal remanent magnetization. $\mathrm{AF}=$ alternating field demagnetization, $\mathrm{TD}=$ thermal demagnetization . $\mathrm{R}=$ rotary core barrel. Download table in CSV format.

\begin{tabular}{|c|c|c|c|}
\hline $\begin{array}{l}\text { Core, section, } \\
\text { interval }(\mathrm{cm})\end{array}$ & Sample ID & $\begin{array}{c}\text { Igneous } \\
\text { unit }\end{array}$ & Treatment \\
\hline \multicolumn{4}{|l|}{ 376-U1527A- } \\
\hline $5 R-1,6-8$ & CUBE9598171 & 1 & TD $610^{\circ}$ \\
\hline 5R-1, 17-19 & CUBE9598091 & 1 & AF $200 \mathrm{mT}$ \\
\hline $6 \mathrm{R}-1,25-27$ & CUBE9598181 & 1 & TD $610^{\circ}$ \\
\hline $6 \mathrm{R}-1-70,70-72$ & CUBE9598121 & 1 & AF $200 \mathrm{mT}$ \\
\hline $6 \mathrm{R}-1,85-87$ & CUBE9598141 & 1 & TD $610^{\circ}$ \\
\hline $6 \mathrm{R}-1,110-112$ & CUBE9598161 & 1 & AF $200 \mathrm{mT}$ \\
\hline \multicolumn{4}{|l|}{ 376-U1527C- } \\
\hline $11 \mathrm{R}-1,30-32$ & CUBE9604061 & $2 \mathrm{~B}$ & AF $70 \mathrm{mT}$ \\
\hline $11 R-1,140-142$ & CUBE9604101 & $2 \mathrm{~B}$ & TD $650^{\circ}$ \\
\hline $11 \mathrm{R}-2,38-40$ & CUBE9604111 & $2 \mathrm{~B}$ & AF $70 \mathrm{mT}$ \\
\hline $11 R-2,92-94$ & CUBE9604181 & $2 B$ & TD $650^{\circ}$ \\
\hline $11 \mathrm{R}-2,131-133$ & CUBE9604441 & $2 \mathrm{~B}$ & AF $70 \mathrm{mT}$ \\
\hline $12 \mathrm{R}-1,78-80$ & CUBE9604191 & $2 \mathrm{~B}$ & $\operatorname{TD} 650^{\circ}$ \\
\hline $12 R-2,65-67$ & CUBE9604241 & $2 \mathrm{~B}$ & TD $650^{\circ}$ \\
\hline $13 R-1,49-51$ & CUBE9604281 & $2 B$ & AF $70 \mathrm{mT}$ \\
\hline $13 R-2,25-27$ & CUBE9604421 & $2 \mathrm{~B}$ & TD $650^{\circ}$ \\
\hline $13 R-3-34-36$ & CUBE9604321 & $2 B$ & AF $70 \mathrm{mT}$ \\
\hline $13 R-3,98-100$ & CUBE9604351 & $2 \mathrm{~B}$ & TD $650^{\circ}$ \\
\hline $14 \mathrm{R}-1,52-54$ & CUBE9605511 & $2 \mathrm{~B}$ & TD $610^{\circ}$ \\
\hline $14 \mathrm{R}-2,29-31$ & CUBE9605551 & $2 \mathrm{~B}$ & TD $610^{\circ}$ \\
\hline $14 \mathrm{R}-3,49-51$ & CUBE9605581 & $2 \mathrm{~B}$ & $\mathrm{AF} 70 \mathrm{mT}$ \\
\hline $15 R-1,25-27$ & CUBE9605651 & $2 \mathrm{~B}$ & $\mathrm{AF} 70 \mathrm{mT}$ \\
\hline $15 R-2,35-37$ & CUBE9605671 & $2 \mathrm{~B}$ & $\mathrm{AF} 70 \mathrm{mT}$ \\
\hline $15 R-2,97-99$ & CUBE9605721 & $2 \mathrm{~B}$ & TD $610^{\circ}$ \\
\hline $14 \mathrm{R}-3,12-14$ & CUBE9605741 & $2 \mathrm{~B}$ & TD $610^{\circ}$ \\
\hline $16 \mathrm{R}-1,24-26$ & CUBE9605771 & $2 \mathrm{~B}$ & TD $610^{\circ}$ \\
\hline $16 R-1,64-66$ & CUBE9605781 & $2 \mathrm{~B}$ & TD $610^{\circ}$ \\
\hline $17 R-1,35-37$ & CUBE9605821 & $2 \mathrm{~B}$ & TD $610^{\circ}$ \\
\hline $17 \mathrm{R}-2,24-26$ & CUBE9605851 & $2 \mathrm{~B}$ & TD $610^{\circ}$ \\
\hline $17 R-2,96-98$ & CUBE9605881 & $2 C$ & AF $70 \mathrm{mT}$ \\
\hline $18 R-1,37-39$ & CUBE9605901 & $2 C$ & AF $70 \mathrm{mT}$ \\
\hline $18 \mathrm{R}-1,135-137$ & CUBE9605951 & $2 C$ & TD $610^{\circ}$ \\
\hline $18 \mathrm{R}-2,35-37$ & CUBE9605971 & $2 C$ & TD $610^{\circ}$ \\
\hline $18 \mathrm{R}-2,77-79$ & CUBE9605991 & $2 C$ & $\mathrm{AF} 70 \mathrm{mT}$ \\
\hline 19R-1, 33-34 & CUBE9606021 & $2 \mathrm{D}$ & TD $610^{\circ}$ \\
\hline $19 R-1,124-126$ & CUBE9606041 & $2 \mathrm{D}$ & TD $610^{\circ}$ \\
\hline $19 R-2,22-24$ & CUBE9606071 & $2 \mathrm{D}$ & AF $70 \mathrm{mT}$ \\
\hline $20 \mathrm{R}-1,101-103$ & CUBE9606121 & $2 \mathrm{D}$ & TD $610^{\circ}$ \\
\hline
\end{tabular}

ratory Information Management System (LIMS) database because it contains the continuous measurements from the entire archive halves, including small pieces. Nevertheless, this approach provided a rapid evaluation of the magnetic properties of the cores to optimize the shipboard discrete sampling. In total, 37 oriented samples (6 from Igneous Unit 1 and 31 from Igneous Unit 2) (Table T8) from the working halves from Site U1527 were selected for detailed measurements of anisotropy of magnetic susceptibility, AF, and thermal demagnetization (TD), as well as isothermal remanence magnetization (IRM) experiments.

\section{Igneous Unit 1}

The analysis of archive section halves from 29.10 to $67.81 \mathrm{mbsf}$ is limited to only two sections with very limited recovery $(\sim 1.2 \mathrm{~m})$. Nevertheless, the unaltered dacite in this interval consistently has large NRM intensities $(>0.5 \mathrm{~A} / \mathrm{m}$ and as much as $10 \mathrm{~A} / \mathrm{m})$ before AF demagnetization and relatively large coercivities. Inclination data of the large oriented pieces are generally characterized by negative values between $-30^{\circ}$ and $-70^{\circ}$, which correspond to normal polarity in the southern hemisphere. Mean susceptibilities measured from the 
Figure $\mathrm{F} 38$. AF demagnetization experiment showing univectorial decay in Sample 376-U1527A-6R-1, 70-72 cm (CUBE9598121), from Igneous Unit 1 with a large NRM before demagnetization $(6.561 \mathrm{~A} / \mathrm{m})$. This sample shows large coercivity and a stable primary magnetization for AFs $>10 \mathrm{mT}$.

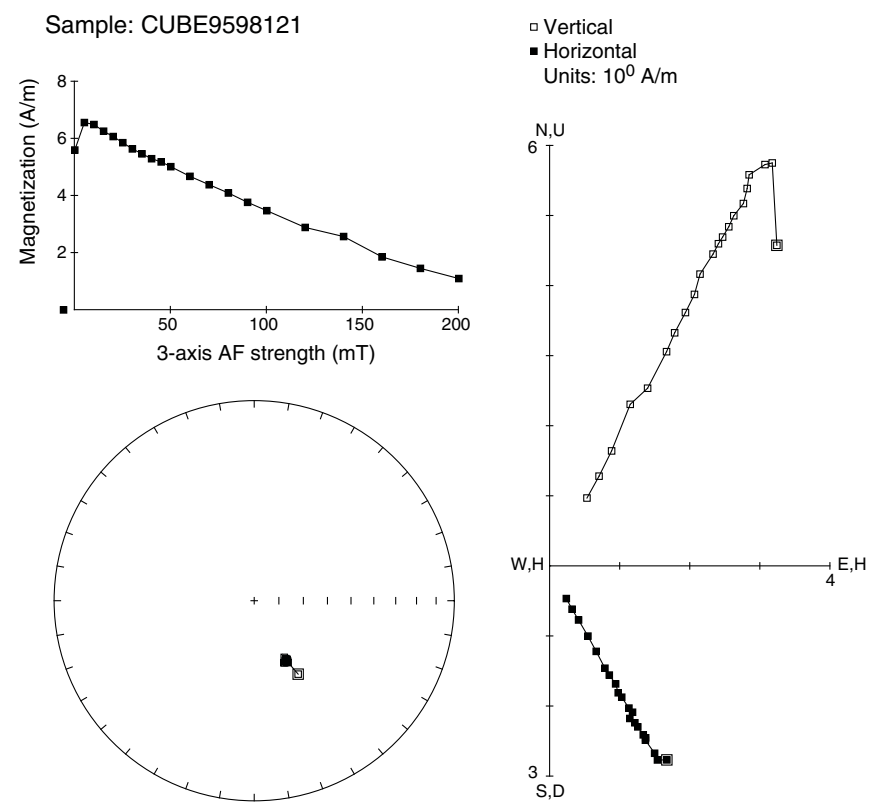

Agico Kappa Bridge KLY 4 for the six fresh dacite samples are large $\left(900 \times 10^{-5}\right.$ to $\left.1900 \times 10^{-5} \mathrm{SI}\right)$ and show good agreement with susceptibility measurements (see Physical properties).

The NRM of three samples (Table T8) was measured before and after AF demagnetization $\leq 200 \mathrm{mT}$ (Figure F38). In general, large NRM intensities $(6.56-9.82 \mathrm{~A} / \mathrm{m})$ were also measured before AF demagnetization for these samples, in agreement with the results from archive halves measured with the cryogenic magnetometer. The soft magnetic drilling overprint (Richter et al., 2007) was removed after AF demagnetization to $10 \mathrm{mT}$, leaving primary components that could be analyzed with principal component analysis (PCA) (Kirschvink, 1980) in vector component diagrams (Zijderveld, 1967). The AF demagnetized samples show relatively large coercivities $(>100 \mathrm{mT}$; confirmed by further IRM experiments) and an average inclination of $-59.8^{\circ}$, calculated using the method of McFadden and Reid (1982). We carried out TD experiments on three other samples. After measuring NRM at room temperature, the samples were shared with the Physical Properties group for moisture and density (MAD) measurements, which required heating the samples to $105^{\circ} \mathrm{C}$. The initial NRM measured before TD $(1.72-9.47 \mathrm{~A} / \mathrm{m})$ was also in agreement with the observed large $(0.5 \mathrm{~A} / \mathrm{m})$ values from the archive halves measured with the cryogenic magnetometer. After the MAD measurements, these samples were thermally demagnetized to a maximum temperature of $610^{\circ} \mathrm{C}$, starting from an initial step of $110^{\circ} \mathrm{C}$ to erase any magnetic overprint as a result of MAD measurements. In general, the samples show a linear decrease in magnetization intensity to $40 \%$ of the original intensity at temperatures around $400^{\circ} \mathrm{C}$ followed by a slightly steeper decrease between $500^{\circ}$ and $600^{\circ} \mathrm{C}$ (Figure F39).

\section{Igneous Unit 2}

In total, 27 archive halves from 185.20 to 234.38 mbsf were measured. The dacite volcaniclastics in this interval have lower NRM intensities $(<0.5 \mathrm{~A} / \mathrm{m})$ before AF demagnetization compared to those in Igneous Unit 1 , as well as lower coercivities ( $\sim 90 \%$ demagnetization
Figure F39. TD experiment using Sample 376-U1527A-6R-1, 25-27 cm (CUBE9598181), from Igneous Unit 1, with a large NRM before demagnetization $(9.468 \mathrm{~A} / \mathrm{m})$. The drilling overprint in this experiment is removed at temperatures $>250^{\circ} \mathrm{C}$, leaving a stable primary component.

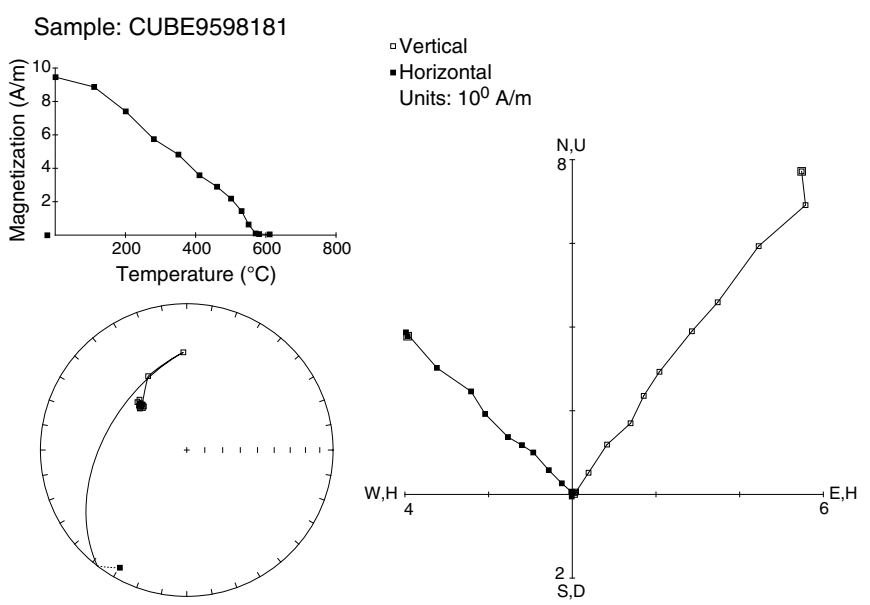

Figure F40. AF demagnetization experiment showing univectorial decay in Sample 376-U1527C-13R-1, 49-51 cm (CUBE9604281), from Igneous Unit 2. This sample shows small coercivity and a stable primary magnetization for AFs $>10 \mathrm{mT}$.

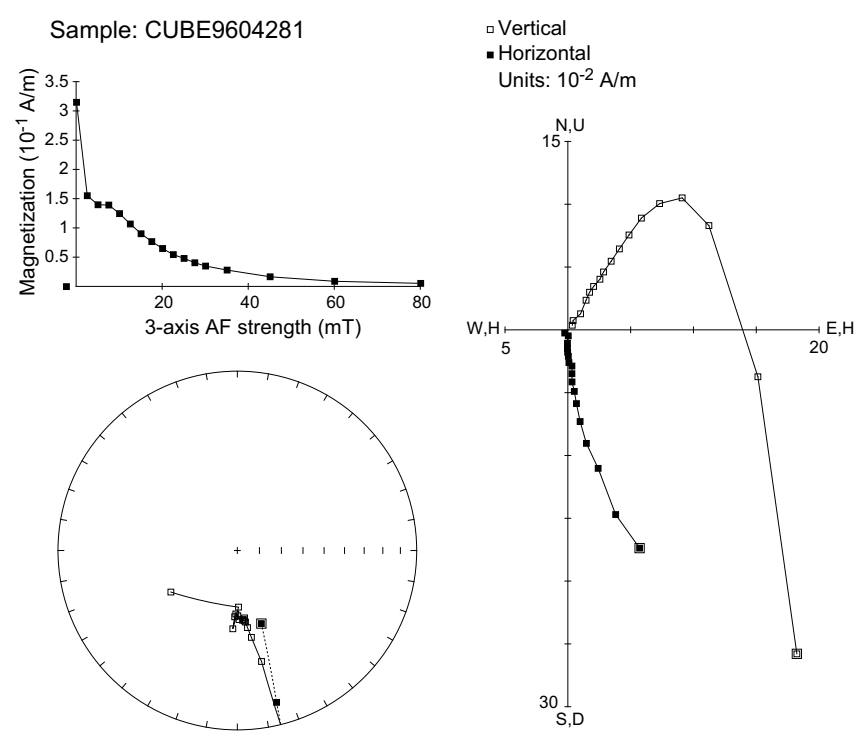

after a $40 \mathrm{mT}$ field in the cryogenic magnetometer). In a few localized parts of the archive section halves, the very high intensities $(>0.5 \mathrm{~A} / \mathrm{m}$ and $\leq 10 \mathrm{~A} / \mathrm{m}$ ) measured with the cryogenic magnetometer are likely caused by an intense magnetic overprint originating from drilling/coring operations and can be explained in light of the significantly smaller coercivities of this igneous unit.

Inclination data from the larger oriented pieces are generally characterized by negative values, again suggesting rocks with normal polarities. Mean susceptibilities measured from the Agico Kappa Bridge KLY 4 for the volcaniclastic samples are also high $\left(1500 \times 10^{-5}\right.$ to 2500 $\times 10^{-5} \mathrm{SI}$ ), with the exception of the samples from below $225 \mathrm{mbsf}$, where measured magnetic susceptibilities are noticeably lower $(60 \times$ $10^{-5}$ to $1500 \times 10^{-5} \mathrm{SI}$ ). The NRM of 12 samples (see Table T8) was measured before and after AF demagnetization $\leq 80 \mathrm{mT}$ (Figure F40), which was enough to demagnetize the samples to less than $10 \%$ of the 
Figure F41. TD experiment using Sample 376-U1527C-11R-1, 140-142 cm (CUBE9605511), from Igneous Unit 2. This sample shows a complex TD curve, with small peaks around $450^{\circ}$ and $570^{\circ} \mathrm{C}$.

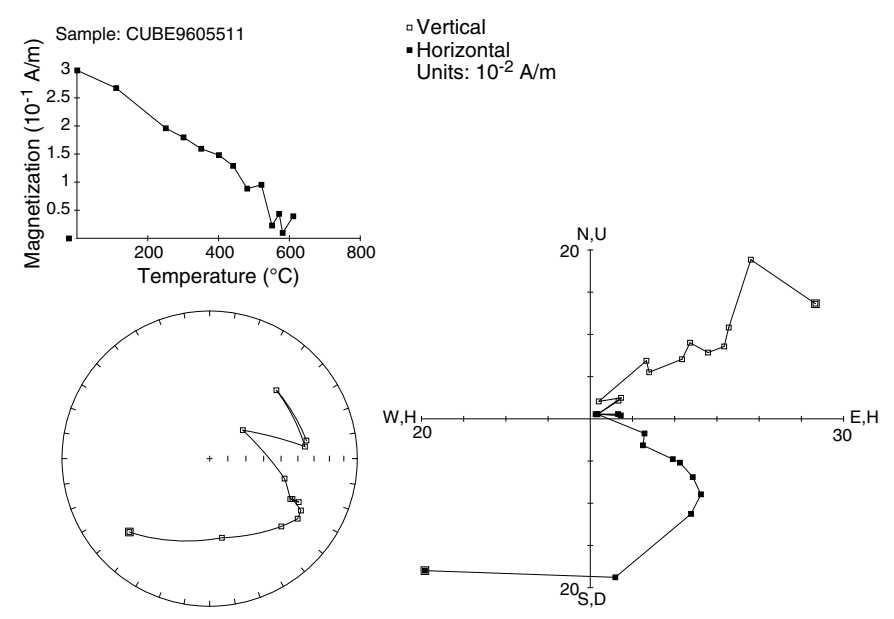

original magnetization intensity. For this igneous unit, the lower NRM intensities $(0.02-0.90 \mathrm{~A} / \mathrm{m})$ measured before AF demagnetization are in substantial agreement with the results from archive halves measured with the cryogenic magnetometer. The small coercivities were also confirmed by additional IRM experiments. Because of the smaller coercivities, the magnetic drilling overprint (Richter et al., 2007) had a larger influence on these samples and was removed after AF demagnetization $>15-20 \mathrm{mT}$, leaving clear primary components that could be analyzed with PCA analysis (Kirschvink, 1980) in vector component diagrams (Zijderveld, 1967) and providing an average inclination of $-59.2^{\circ}$, calculated using the method of McFadden and Reid (1982).

We carried out TD experiments on the remaining 19 samples. Similar to samples from Igneous Unit 1, samples from Igneous Unit 2 were shared with the Physical Properties group for MAD measurements. The initial NRM measured before TD $(0.02-0.93 \mathrm{~A} / \mathrm{m})$ was also in agreement with the smaller values observed with the cryogenic magnetometer on the archive halves. Lower magnetization intensities were measured below $225 \mathrm{mbsf}$, which is in agreement with the susceptibility results. The TD experiments were carried out to temperatures $>600^{\circ} \mathrm{C}$ (see Table T8) starting from an initial step of $110^{\circ} \mathrm{C}$ to erase the magnetic overprint from MAD experiments. The samples show a general linear decrease of magnetization intensity to less than $50 \%$ of the original intensity at $\sim 400^{\circ} \mathrm{C}$ and a complete demagnetization at temperatures greater than $\sim 570^{\circ} \mathrm{C}$. A few samples above $200 \mathrm{mbsf}$ show a slight magnetization increase between $400^{\circ}$ and $500^{\circ} \mathrm{C}$ followed by a smaller peak at $\sim 570^{\circ} \mathrm{C}$ (Figure F41).

\section{Discussion}

Magnetic directions calculated using PCA on discrete samples from Igneous Units 1 and 2 (average inclination $=-59.8^{\circ}$ for unaltered dacite and $-59.2^{\circ}$ for altered volcaniclastics, respectively) consistently show univectorial decay toward the origin at AF steps greater than $15 \mathrm{mT}$. This set of directions is assumed to represent remanent magnetization recorded at the time these rocks cooled. Average inclinations for both lithologies are very similar to the GAD inclination of $-55^{\circ}$ (Figure F42), which indicates a very young age for the primary magnetization component that is almost certainly from the current normal Chron, C1n (Cande and Kent, 1995).
Figure F42. NRM intensity before demagnetization and inclination from PCA after AF and TD experiments, Site U1527. Black vertical lines are GAD inclinations with normal and reversed polarities of $-55^{\circ}$ and $+55^{\circ}$, respectively, at the latitude of Brothers volcano.

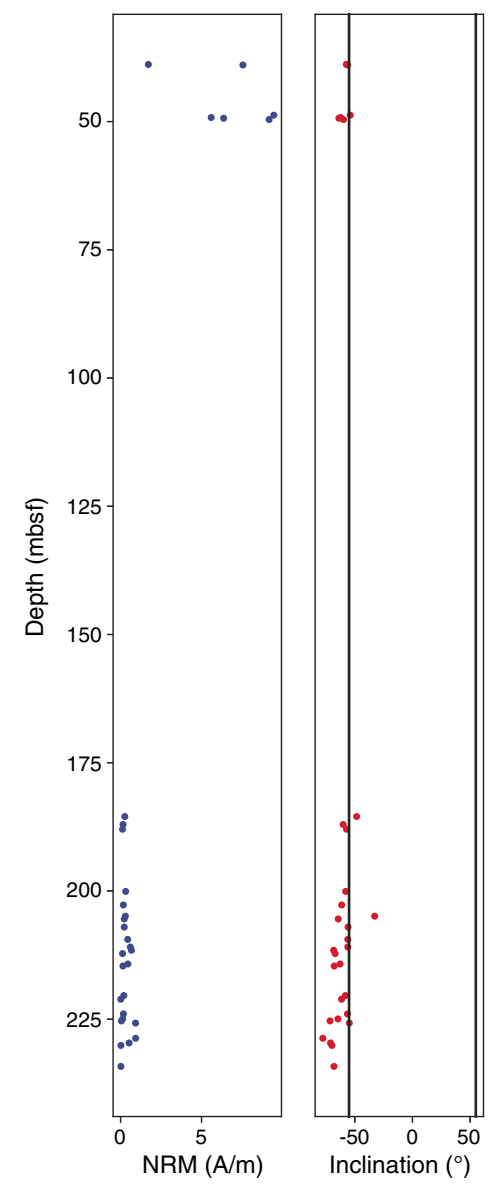

The two units have significantly different magnetic properties. Despite the limited sampling of unaltered dacite from Igneous Unit 1, the discrete samples show consistent TD curves (Figure F39) with a linear decrease of magnetization intensity to temperatures around $400^{\circ} \mathrm{C}$ followed by a more rapid decline between $500^{\circ}$ and $600^{\circ} \mathrm{C}$. This suggests that these samples contain pure magnetite (Curie temperature $=\sim 575^{\circ} \mathrm{C}$; Tauxe, 2010) and titanomagnetite with variable Ti content because increasing Ti content produces a decrease in the Curie temperature (O'Reilly, 1984). The relatively high coercivities measured on discrete samples and archive halves suggest the prevalence of single domain magnetic grains (Tauxe, 2010). No significant transformation of magnetic minerals during heating is evident from the TD curves. The large mean susceptibilities for the six samples from Igneous Unit 1 imply a significant content of magnetite (0.2-0.5 vol\%) using the empirical relation of Grant and West (1965).

Conversely, Igneous Unit 2 shows lower NRM intensities before demagnetization (Figure F42). However, the mean magnetic susceptibilities are generally comparable to those measured from Igneous Unit 1, suggesting a similar magnetite content using the same empirical relation of Grant and West (1965). This is also confirmed by IRM experiments in which samples from both units reach similar saturation magnetizations in excess of $100 \mathrm{~A} / \mathrm{m}$. Samples from Unit 
2, however, show significantly smaller coercivities and complex TD curves (Figure F41). A possible explanation for the increase in magnetization around $450^{\circ}$ and $570^{\circ} \mathrm{C}$ could be a combination of pure magnetite, titanomaghemite, and titanomagnetite, with titanomaghemite inverting to magnetite at temperatures $>400^{\circ} \mathrm{C}$ (Özdemir and O'Reilly, 1982) and Ti-poor titanomagnetite exsolving to pure magnetite at $575^{\circ} \mathrm{C}$. If this was the case, however, we would expect an increase in MS after TD that was not observed in the samples from Unit 2, for which the MS decreased to less than half of the original values after heating. This result appears to exclude the presence of titanomaghemite grains. The complexity of the TD curve is also mirrored in the complex geometry of the Zijderveld plots (Figure F41; Zijderveld, 1967), where in some cases a consistent univectorial component could not be extracted.

\section{Physical properties}

Physical property data for Site U1527 were for Holes U1527A and U1527C (Figure F43). Core temperatures from Hole U1527A were $\sim 13^{\circ} \mathrm{C}$ upon arrival in the splitting room and $\sim 15^{\circ}-19^{\circ} \mathrm{C}$ for cores from Hole U1527C. Cores were left to equilibrate to room temperature $\left(\sim 20^{\circ} \mathrm{C}\right)$ prior to further analyses. Recovered cores were fragmented and of variable thickness, so continuous measurements on whole-round cores (i.e., gamma ray attenuation bulk density, magnetic susceptibility loop [MSL] sensor, and natural gamma radiation [NGR]) yielded noisy data (see Physical properties in the Expedition 376 methods chapter [de Ronde et al., 2019a]). Measurements of $P$-wave velocity, density, porosity, MS, and thermal conductivity made on section-half cores and discrete cubes therefore provide the basis for the petrophysical characterization of Site U1527. To encompass the various igneous lithologies and alteration types, 6 discrete cubes were cut from Hole U1527A and 31 cubes were cut from Hole U1527C. These cubes were shared between paleomagnetic, MAD, and $P$-wave velocity measurements. Thermal conductivity was measured on 1 piece of section-half core from Hole U1527A and 13 pieces of section-half core from Hole U1527C.

\section{Density and porosity}

Individual porosity and bulk, dry, and grain density values are shown in Table T9. Bulk density values range from $1.70 \mathrm{~g} / \mathrm{cm}^{3}$ in fresh dacite (Igneous Unit 1) to $2.46 \mathrm{~g} / \mathrm{cm}^{3}$ in Hole U1527C in Igneous Subunit 2c with a mean value of $2.17 \mathrm{~g} / \mathrm{cm}^{3}$ for the site (Figure F43). Grain density values show little variability with depth and have a mean value of $2.68 \mathrm{~g} / \mathrm{cm}^{3}$ (Figure F43). An anomalously low grain density value $\left(2.36 \mathrm{~g} / \mathrm{cm}^{3} ; 185.5 \mathrm{mbsf}\right)$ was recorded on one sample at the top of Igneous Subunit 2b in Hole U1527C. For this discrete sample, only the bulk density and $P$-wave velocity data are considered representative.

Porosity varies inversely with bulk density throughout Site U1527 (Figures F43, F44). Accordingly, the highest porosity values ( 37 and 54 vol\%) correspond to the unaltered vesicular lava in Core 376-U1527A$5 \mathrm{R}$ that has the lowest bulk density values. Meanwhile, the lowest porosity values correspond to an unaltered dacite with high bulk density in Igneous Unit 1 (20 vol\%; $49.2 \mathrm{mbsf}$ ) and the dense samples within Igneous Subunit 2c (minimum porosity of $15 \mathrm{vol} \%$ at $221 \mathrm{mbsf}$ ).

Table T9. Moisture and density (MAD), Holes U1527A and U1527C. Download table in CSV format.

Figure F43. Physical properties, Holes U1527A and U1527C. $P$-wave velocity values are the mean for each measurement.

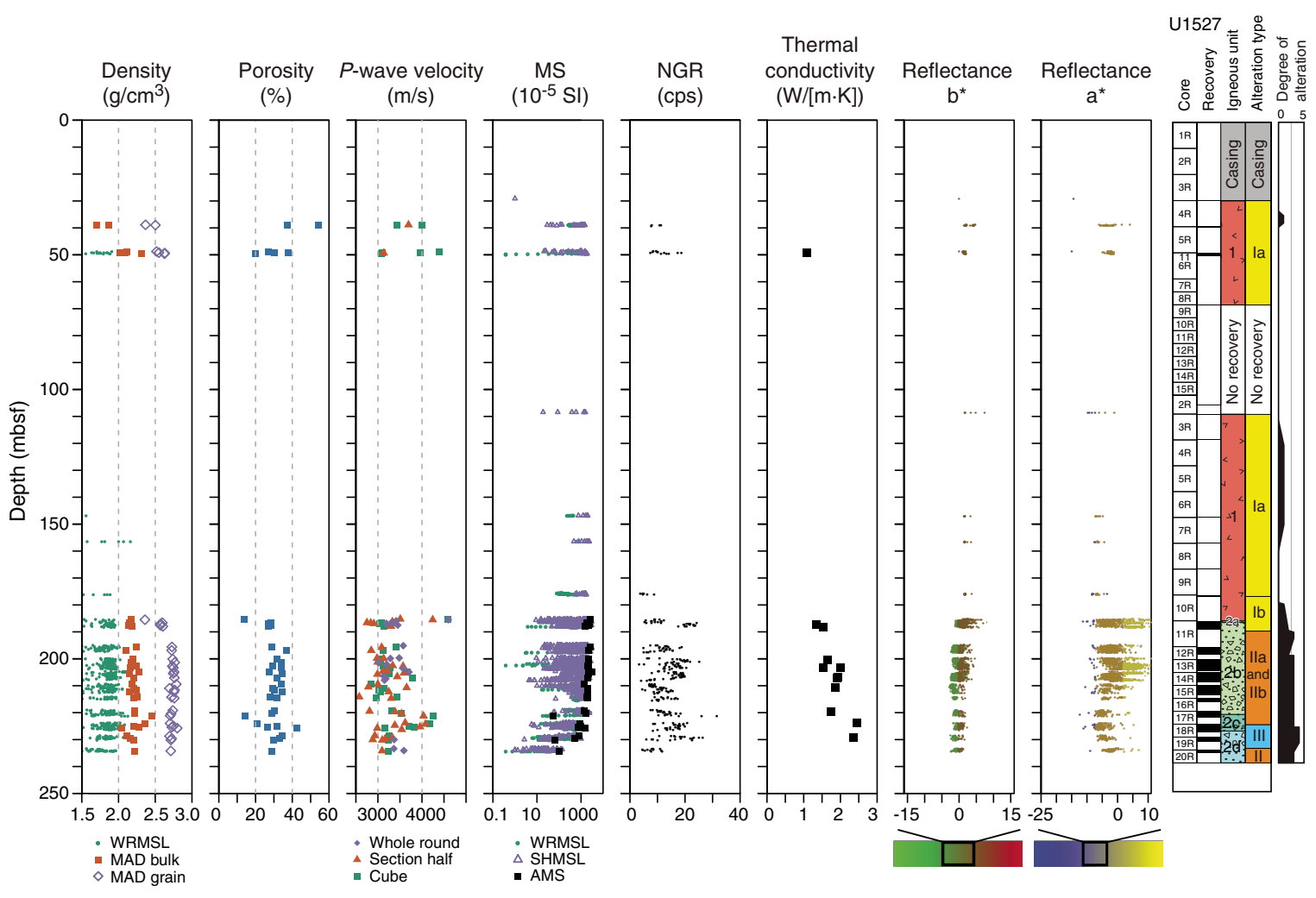


Figure F44. MAD and $P$-wave velocity data for discrete samples, Holes U1527A and U1527C. Lines = best fit regression.
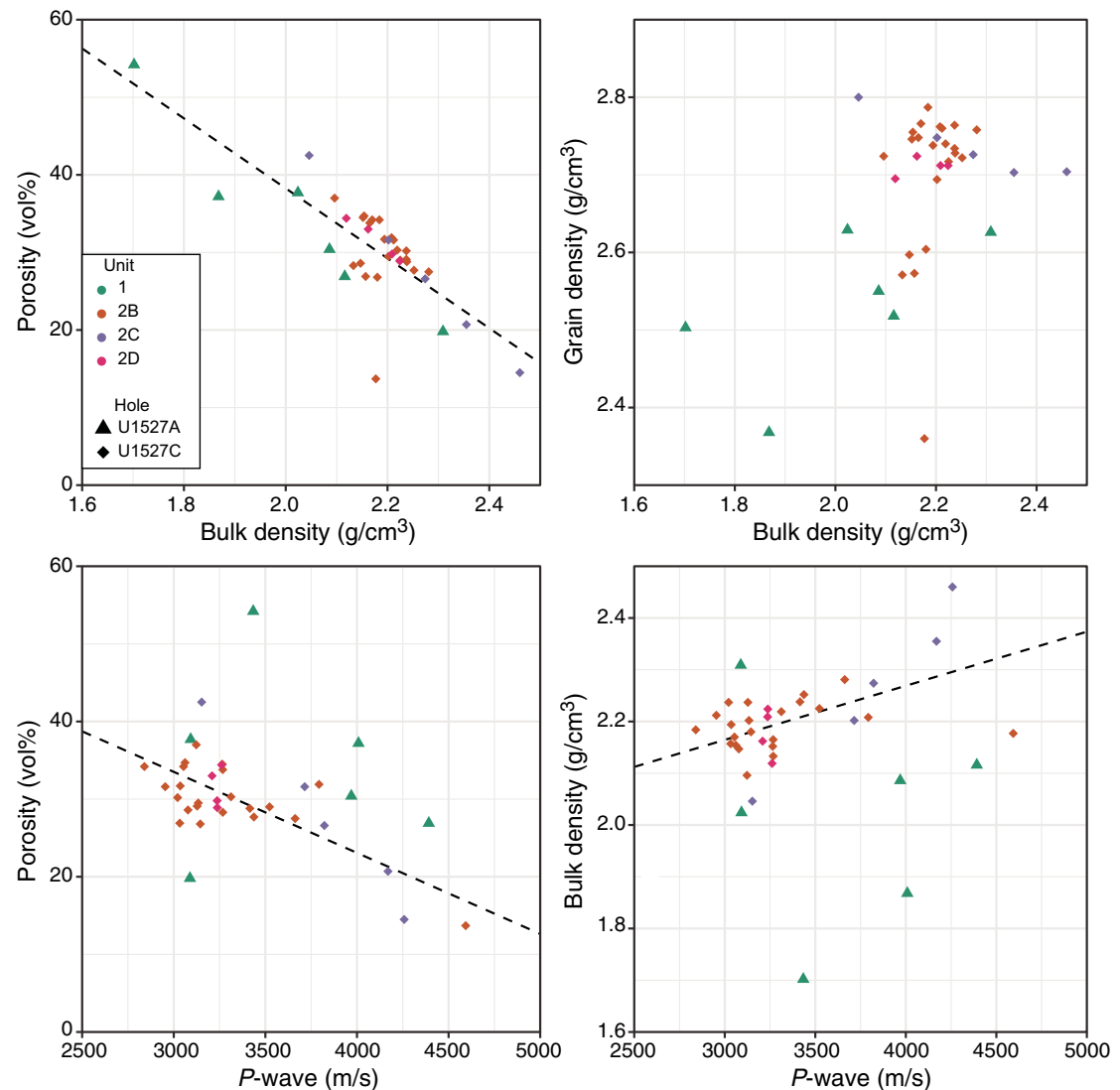

\section{P-Wave velocity}

$P$-wave velocities were measured on whole-round core pieces in the $x$ - and $y$-directions, on section-half cores in the $x$-direction, and on discrete cubes in the $x$-, $y$-, and $z$-directions (see Physical properties in the Expedition 376 methods chapter [de Ronde et al., 2019a]). In total, $99 P$-wave measurements were made at Site U1527, of which 19 were on whole-round cores, 43 were on section half cores, and 37 were on discrete cubes (Figure F43). Measured $P$ wave velocity and calculated anisotropy data are shown in Table T10. Measured velocities are consistent among the three measurement types.

Measured $P$-wave velocities at Site U1527 range from $\sim 2580$ to $\sim 4750 \mathrm{~m} / \mathrm{s}$ with a mean value of $\sim 3390 \mathrm{~m} / \mathrm{s}$. Unaltered dacitic samples from Igneous Unit 1 have a wide range of $P$-wave velocity values ( $\sim 3100$ to $\sim 4400 \mathrm{~m} / \mathrm{s}$ ) with anisotropy values $\leq 5 \%$ (Figure F45). One section half core from Igneous Subunit 2a has a $P$-wave velocity of $\sim 3500 \mathrm{~m} / \mathrm{s}$. Samples from Igneous Subunits 2b, 2c, and 2d, which contain a variety of altered volcaniclastic rocks, cover a range of $P$-wave velocities similar to that of Unit 1 . However, in contrast to Unit 1 , these samples have $P$-wave anisotropy values that range from $0 \%$ to $18 \%$ between the $z$-direction (vertical) and the $x$ - $y$ plane (horizontal) and between $0 \%$ and $23 \%$ between the $x$ - and $y$-axes. There is no consistent relationship in the direction $(x, y$, or $z)$ or magnitude of the observed anisotropy (Figure F45).

In the altered volcanic material from Igneous Subunits $2 b, 2 c$, and $2 \mathrm{~d}$, higher $P$-wave velocities are associated with lower porosities and higher bulk densities (Figure F44). Generally, these three parameters are relatively constant with depth within these subunits.

Table T10. P-wave velocity, Holes U1527A and U1527C. Download table in CSV format.

However, the transition from Subunit $2 b$ to Subunit 2c (see Igneous petrology and volcanology) is marked by a sudden increase in $P$ wave velocity at the top of Subunit 2c to $\sim 4260 \mathrm{~m} / \mathrm{s}$ at $221.11 \mathrm{mbsf}$ (Figure F46), which corresponds to the sample with lowest porosity (15 vol\%) and highest bulk density $\left(2.46 \mathrm{~g} / \mathrm{cm}^{3}\right)$. $P$-wave velocity values then decrease with depth throughout the rest of Subunit 2c with a corresponding increase in porosity and decrease in bulk density (to $\sim 3000 \mathrm{~m} / \mathrm{s}, 43 \mathrm{vol} \%$, and $2.05 \mathrm{~g} / \mathrm{cm}^{3}$, respectively, at 225.76 mbsf). This variation occurs over the same depth interval in which structural deformation and a change from Alteration Type II to Alteration Type III is observed (see Alteration), with greater deformation corresponding to the top of Subunit 2c, where the highest $P$ wave velocity and bulk density and lowest porosity value are observed. The $P$-wave velocity data from Subunit $2 \mathrm{~d}$ are very similar to those from Subunit 2b (Figures F43, F45; Table T10). In the fresh volcanic samples from Unit 1, there are no discernible relationships between $P$-wave velocity and bulk density or between $P$-wave velocity and porosity (Figure F44).

\section{Magnetic susceptibility}

Figure F43 shows the variation in MS in Holes U1527A and U1527C as measured by the Whole-Round Multisensor Logger (WRMSL) MSL sensor and the Section Half Multisensor Logger (SHMSL) point magnetic susceptibility (MSP) sensor alongside the bulk MS measurements of discrete cubes from Igneous Subunits $2 b$, 2c, and 2d (see Paleomagnetism). SHMSL MSP data are in good 
Figure F45. P-wave velocity and anisotropy, Holes U1527A and U1527C.

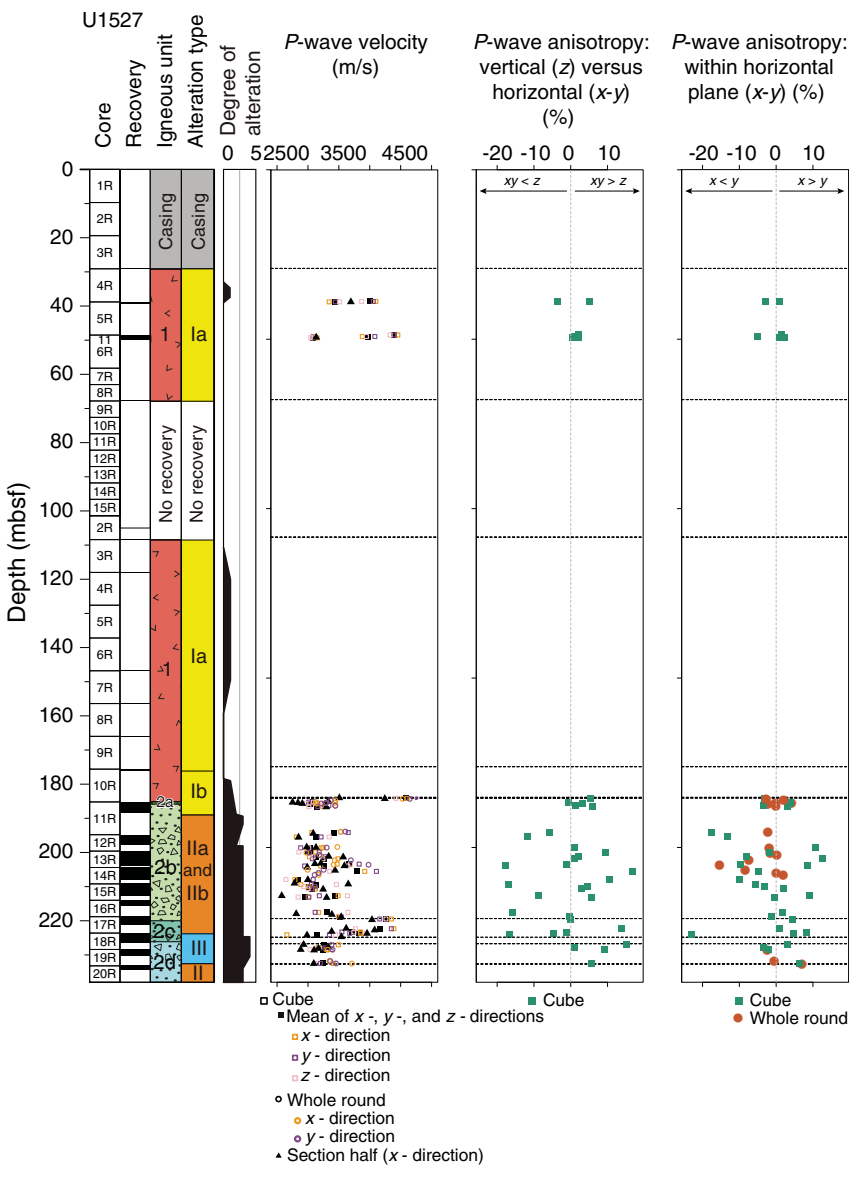

Figure F46. Physical properties measured on discrete samples from Cores 376-U1527C-17R, 18R, and 19R and Igneous Subunits 2b, 2c, and 2d. Core photograph shows a fault and indication of deformation intensity decreasing from the upper to lower boundaries of Subunit $2 \mathrm{c}$ associated with variations in petrophysical properties (see text).

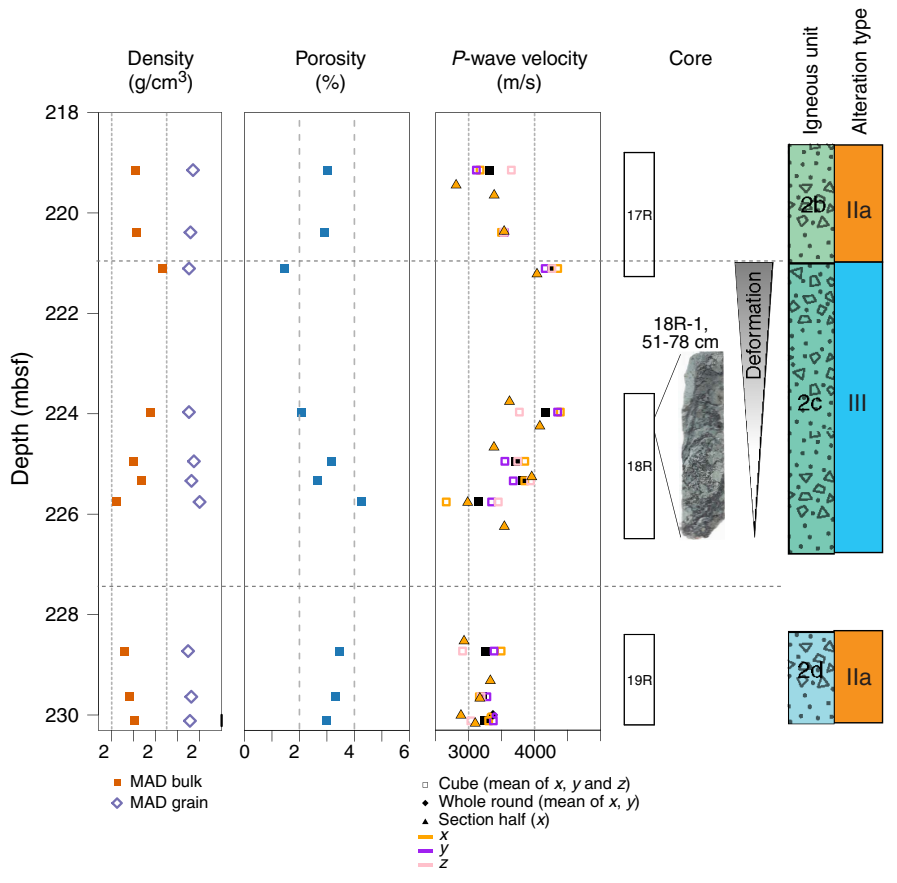

agreement with the bulk MS of discrete cubes. In general, Igneous Unit 2 has higher MS values (maximum $=\sim 3000 \times 10^{-5} \mathrm{SI}$ ) than Igneous Unit 1 (maximum $=\sim 2330 \times 10^{-5} \mathrm{SI}$ ), which corresponds to an observed increase in minerals with high MS in Unit 2 (see Igneous petrology and volcanology). These minerals are heterogeneously distributed within core sections, as demonstrated by the comparison of WRMSL MSL and SHMSL MSP data obtained for Core 376-U1527A-14R in Subunit 2b (Figure F47). For sections of this core unaffected by fragmentation, WRMSL MSL data reveal a constant bulk MS with depth, whereas SHMSL MSP data reveal the variation in magnetically susceptible minerals contained in just the uppermost few millimeters of the split half surface (see Physical properties in the Expedition 376 methods chapter [de Ronde et al., 2019a]). Although Unit 2 has higher MS overall than Unit 1, MS decreases with depth through Subunits $2 \mathrm{c}$ and $2 \mathrm{~d}$, which corresponds to the decrease in magnetite through these depths (see Alteration).

\section{Natural gamma radiation}

NGR measurements are summarized in plots of total counts per second versus depth (Figure F43). NGR counts depend on core thickness, so fragmented material results in lower values (see Physical properties in the Expedition 376 methods chapter [de Ronde et al., 2019a]). A visual comparison of counts per second to the quality of core recovery indicates that the range of NGR values obtained largely reflects intervals of low or fragmented recovery. Therefore, qualitative comparisons of NGR values are made only between intervals that contain coherent pieces with lengths $>20 \mathrm{~cm}$. Using this criterion, values are generally $\sim 20$ counts/s throughout Igneous Units 1 and 2 . An exception occurs at the transition between Igneous Subunits $2 \mathrm{~b}$ and 2c and Alteration Types II and III, where NGR increases to $>30$ counts/s despite originating from smaller pieces of fragmented core. This corresponds to an increase in $\mathrm{K}_{2} \mathrm{O}$ wt\% measured by pXRF in this depth interval (see Igneous petrology and volcanology).

\section{Thermal conductivity}

At Site U1527, thermal conductivity was measured on 11 samples generally representative of lithologic and/or alteration changes (Table T11). Values range from 1.09 to $2.45 \mathrm{~W} /(\mathrm{m} \cdot \mathrm{K})$ with a median value of $1.81 \mathrm{~W} /(\mathrm{m} \cdot \mathrm{K})$ (Figure F43). The lowest value is in a sample of vesicular unaltered dacite from Igneous Unit 1 because the low thermal conductivity of the seawater within the vesicles reduces the overall thermal conductivity of the sample. Within Igneous Unit 2, variations in thermal conductivity reflect variations in the clast-matrix ratio and the alteration mineral assemblages present. Waterrich clay minerals contribute to lower thermal conductivity values, whereas minerals such as pyrite, silica, and magnetite have higher thermal conductivities. The observed variations are greater than the error associated with the individual measurements and can be closely spaced in depth, reflecting the heterogeneity of mineral composition and distribution even within one identified igneous subunit or alteration type (Figure F48). The highest thermal conductivity value recorded at Site U1527 is in the altered volcaniclastic rocks in Igneous Subunit 2c, which is also the zone of structural deformation associated with variations in $P$-wave velocity, density, porosity, and NGR counts.

\section{Reflectance colorimetry}

The reflectance colorimetry data obtained with the SHMSL are helpful in identifying the transitions between the interlayered Alteration Subtypes IIa and IIb, which are associated with a color change (see Alteration). Subtype IIa (green-gray) is characterized by a low 
Figure F47. Physical properties for Core 376-U1527C-14R, Igneous Subunit 2b, with interlayered Alteration Subtypes Ila and IIb. Reflectance spectrophotometry and colorimetry $b^{*}$ parameter highlights Alteration Subtypes Ila (green-gray, $b^{*}<0$ ) and llb (yellow-brown, $b^{*}>0$ ).

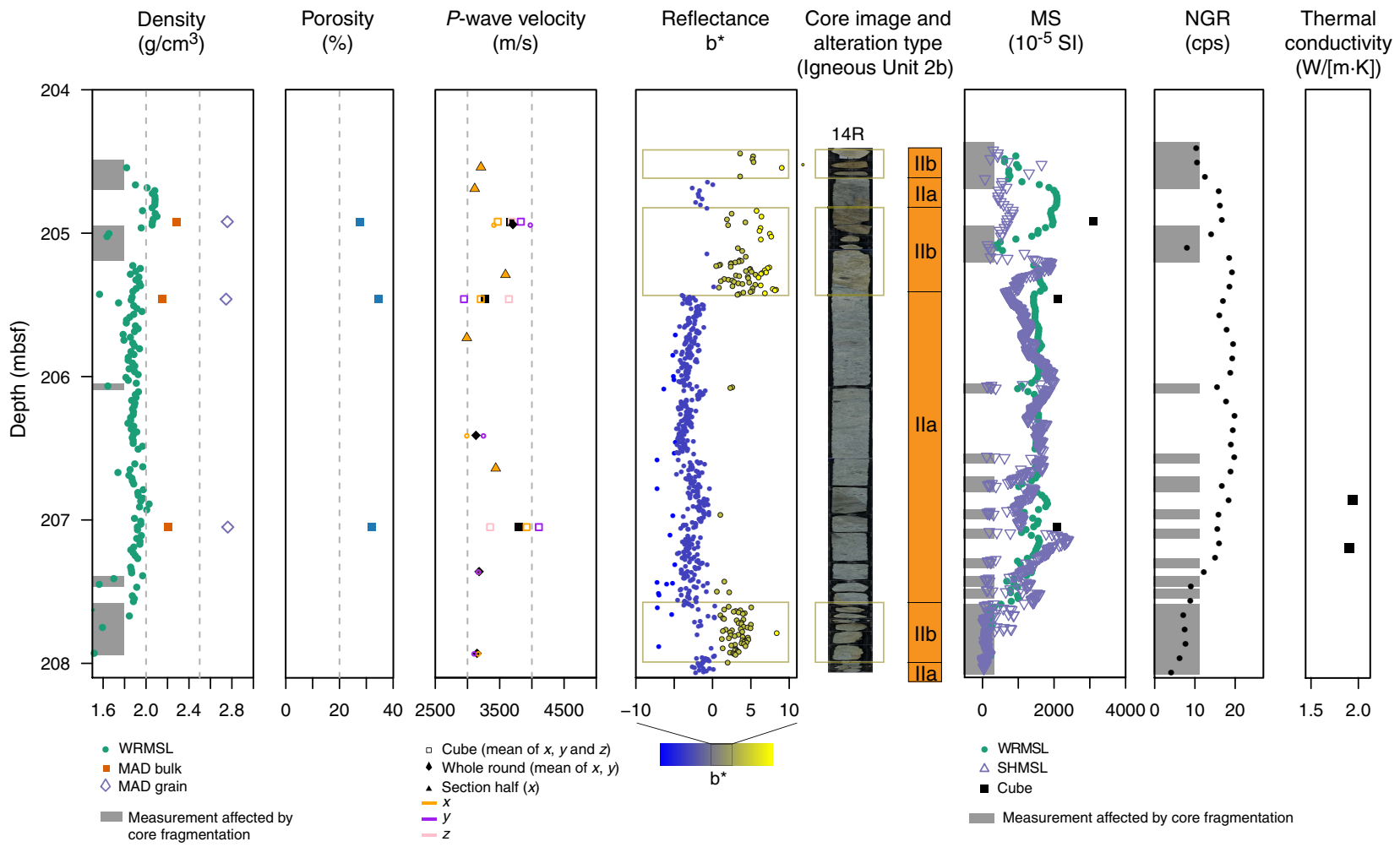

Table T11. Thermal conductivity, Holes U1527A and U1527C. Download table in CSV format.

Figure F48. Thermal conductivity measured on section-half samples from Igneous Unit $2 b$, Site U1527. Error bars show $\pm 1 \sigma$ deviation of the mean.

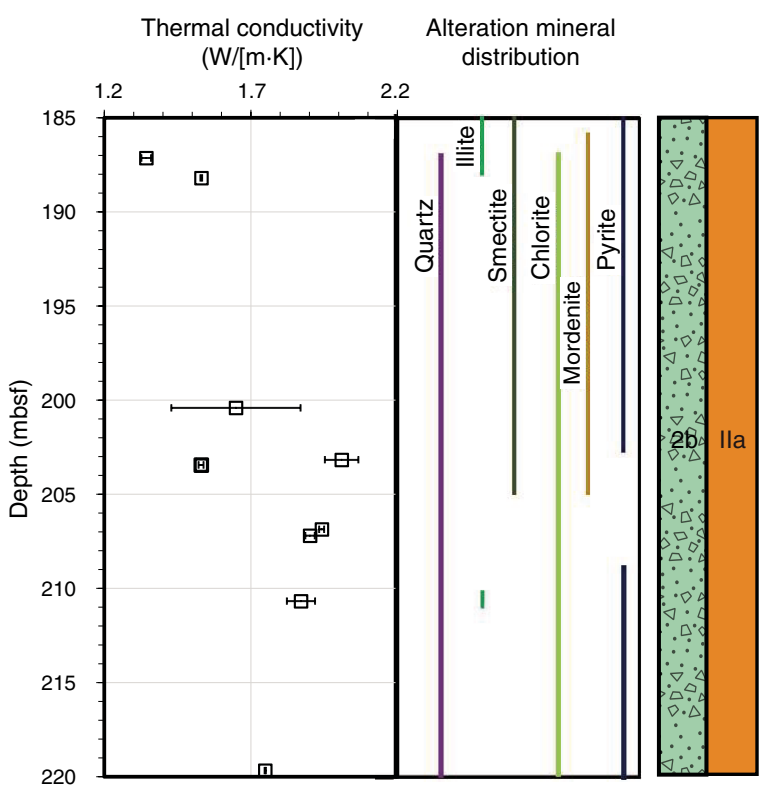

b* parameter, whereas Subtype IIb (yellow-brown) is characterized by a high b* parameter (Figures F43, F47).

\section{Integration of observations}

The characteristic physical properties of Igneous Unit 1 (low bulk density, high porosity, wide range in $P$-wave velocities, and low thermal conductivity) are comparable to those reported for similar samples of unaltered vesicular dacite lavas from the PACMANUS hydrothermal field drilled during ODP Leg 193 (Shipboard Scientific Party, 2002). There is more variation in physical properties in Igneous Unit 2 than in Igneous Unit $1 . P$-wave anisotropy without a specific orientation may reflect the random orientation of volcanic clasts and the large variation of clast-matrix ratios. It suggests a lack of significant subsequent stress or strain overprint, consistent with the limited number of veins (see Structural geology). Sharp changes in density, porosity, and $P$-wave velocity are recorded at the Igneous Subunit $2 b-2 c$ transition, which corresponds to a zone of structural deformation. Qualitative assessment of NGR data also identifies high count rates in Subunit 2c that may correlate with potassium-rich areas of clay minerals or other minerals associated with radiogenic isotopes. Thermal conductivity values within the altered Subunits $2 b, 2 c$, and $2 \mathrm{~d}$ are comparable to those of similarly altered volcanics from the PACMANUS field (Shipboard Scientific Party, 2002). The variations in thermal conductivity over small depths within the same alteration type reflect the heterogeneity in the distributions of alteration minerals, which may have resulted from temporal and spatial variability in alteration processes (see Geochemistry). 


\section{Microbiology}

\section{Site U1527}

\section{Hole U1527A}

Sampling efforts were focused on cores with softer materials (i.e., clays) or rocks with evidence of hydrothermal alteration and/or fracturing fills, such as veins. Because the recovered material in Hole U1527A was mainly relatively fresh volcanic rock, no samples were collected for microbiological analyses.

\section{Hole U1527C}

Five whole-round samples (11-20 cm long) were collected from Hole U1527C (Figure F49). The pieces were selected based on various criteria, including (1) a good level of core recovery (because a minimum of $11 \mathrm{~cm}$ is required for routine microbiology sampling), (2) representation of various degrees of alteration, and (3) the presence of softer materials, such as clays. Samples collected for postexpedition research include fixed samples for cell counts to quantify microbial and viral biomass, frozen samples for DNA extraction to describe the diversity and RNA extraction to characterize activity of the microbial community, and whole-round samples to measure viral and microbial activity. For all five samples, we established nutrient enrichment experiments to attempt culturing the microbial communities.

An adenosine triphosphate test was performed on board to identify signs of bacterial life. Detection was not possible due to denaturation of the luciferase enzyme by compounds found in the recovered material. Addition of the sample to the luciferin/luciferase solution resulted in a complete inactivation of the luciferase enzyme and fluorescence levels below the negative control, suggesting that the luciferase enzyme was denatured by a component in the rock sample. According to the manufacturer's instructions, arsenate compounds denature the enzyme luciferase. This result does not refute the presence of a subsurface biosphere inhabiting Brothers volcano.

Contamination testing was conducted during drilling operations using the tracer perfluoromethyl decaline (PFMD). Drilling

Figure F49. Whole-round samples collected for microbiology, Hole U1527C.

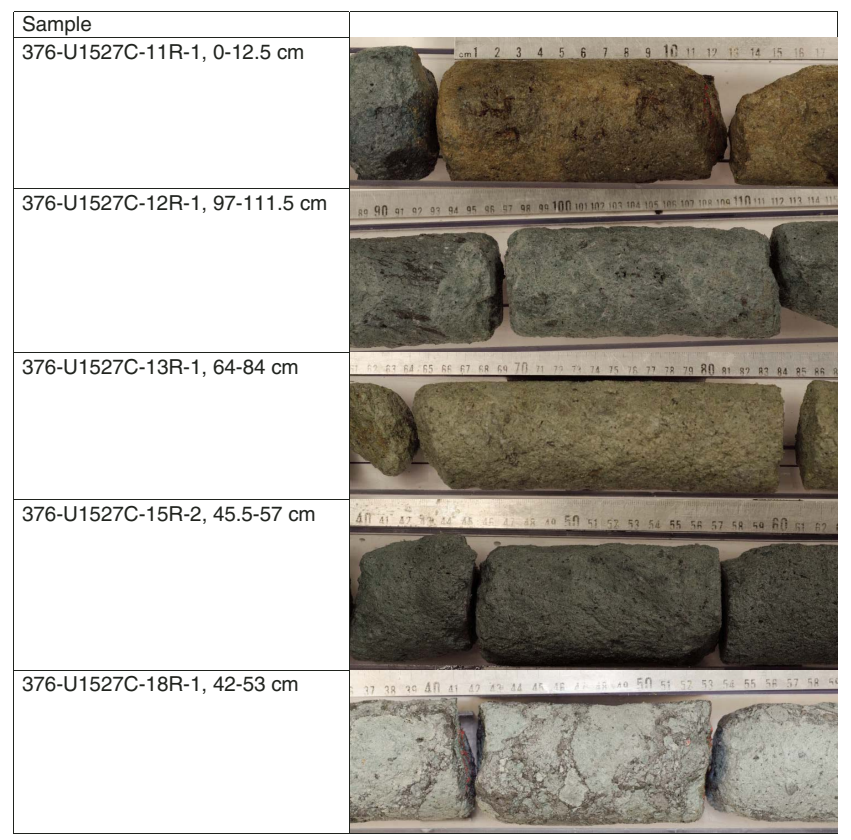

fluid for Hole U1527C, as well as the exterior (after cleaning) and interior of each whole-round sample, was collected for detection of PFMD. When possible, we also collected $5 \mathrm{~mL}$ of core liner fluid on the catwalk immediately after core recovery. All samples were quickly placed into $20 \mathrm{~mL}$ headspace glass vials with metal caps and Teflon seals. The vials were heated at $70^{\circ} \mathrm{C}$ for $10 \mathrm{~min}$ to volatilize any PFMD present. The quantity of PFMD present in the sample was detected using an Agilent gas chromatograph with an electron capture detector. PFMD was routinely detected in the drilling fluids, but it was barely above detection limits on the cleaned outsides and insides of the cores, showing that penetration of drilling fluids into the interior of whole-round cores was minimal.

\section{References}

Alt, J.C., 2003. Hydrothermal fluxes at mid-ocean ridges and on ridge flanks. Comptes Rendus Geoscience, 335(10-11):853-864. https://doi.org/10.1016/j.crte.2003.02.001

Cande, S.C., and Kent, D.V., 1995. Revised calibration of the geomagnetic polarity timescale for the Late Cretaceous and Cenozoic. Journal of Geophysical Research: Solid Earth, 100(B4):6093-6095. https://doi.org/10.1029/94JB03098

Caratori Tontini, F., de Ronde, C.E.J., Yoerger, D., Kinsey, J.C., and Tivey, M., 2012. 3-D focused inversion of near-seafloor magnetic data with application to the Brothers Volcano hydrothermal system, southern Pacific Ocean, New Zealand. Journal of Geophysical Research: Solid Earth, 117(B10):B10102. https://doi.org/10.1029/2012JB009349

Chester, F.M., Mori, J., Eguchi, N., Toczko, S., and the Expedition 343/343T Scientists, 2013. Proceedings of the Integrated Ocean Drilling Program, 343/343T: Tokyo (Integrated Ocean Drilling Program Management International, Inc.). https://doi.org/10.2204/iodp.proc.343343T.2013

Delacour, A., Früh-Green, G.L., Bernasconi, S.M., Schaeffer, P., and Kelley, D.S., 2008. Carbon geochemistry of serpentinites in the Lost City hydrothermal system $\left(30^{\circ} \mathrm{N}, \mathrm{MAR}\right)$. Geochimica et Cosmochimica Acta, 72(15):3681-3702. https://doi.org/10.1016/j.gca.2008.04.039

de Ronde, C.E.J., Hannington, M.D., Stoffers, P., Wright, I.C., Ditchburn, R.G., Reyes, A.G., Baker, E.T., et al., 2005. Evolution of a submarine magmatichydrothermal system: Brothers Volcano, southern Kermadec arc, New Zealand. Economic Geology, 100(6):1097-1133. https://doi.org/10.2113/gsecongeo.100.6.1097

de Ronde, C.E.J., Humphris, S.E., and Höfig, T.W., 2017. Expedition 376 Scientific Prospectus: Brothers Arc Flux. International Ocean Discovery Program. https://doi.org/10.14379/iodp.sp.376.2017

de Ronde, C.E.J., Humphris, S.E., Höfig, T.W., Brandl, P.A., Cai, L., Cai, Y., Caratori Tontini, F., Deans, J.R., Farough, A., Jamieson, J.W., Kolandaivelu, K.P., Kutovaya, A., Labonté, J.M., Martin, A.J., Massiot, C., McDermott, J.M., McIntosh, I.M., Nozaki, T., Pellizari, V.H., Reyes, A.G., Roberts, S., Rouxel, O., Schlicht, L.E.M., Seo, J.H., Straub, S.M., Strehlow, K., Takai, K., Tanner, D., Tepley III, F.J., and Zhang, C., 2019a. Expedition 376 methods. In de Ronde, C.E.J., Humphris, S.E., Höfig, T.W., and the Expedition 376 Scientists, Brothers Arc Flux. Proceedings of the International Ocean Discovery Program, 376: College Station, TX (International Ocean Discovery Program). https://doi.org/10.14379/iodp.proc.376.102.2019

de Ronde, C.E.J., Humphris, S.E., Höfig, T.W., and the Expedition 376 Scientists, 2019b. Supplementary material,

https://doi.org/10.14379/iodp.proc.376supp.2019. Supplement to de Ronde, C.E.J., Humphris, S.E., Höfig, T.W., and the Expedition 376 Scientists, 2019. Brothers Arc Flux. Proceedings of the International Ocean Discovery Program, 376: College Station, TX (International Ocean Discovery Program). https://doi.org/10.14379/iodp.proc.376.2019

de Ronde, C.E.J., Massoth, G.J., Butterfield, D.A., Christenson, B.W., Ishibashi, J., Ditchburn, R.G., Hannington, M.D., et al., 2011. Submarine hydrothermal activity and gold-rich mineralization at Brothers Volcano, Kermadec arc, New Zealand. Mineralium Deposita, 46(5-6):541-584. https://doi.org/10.1007/s00126-011-0345-8 
Dziak, R.P., Haxel, J.H., Matsumoto, H., Lau, T.K., Merle, S.G., de Ronde, C.E.J., Embley, R.W., and Mellinger, D.K., 2008. Observations of regional seismicity and local harmonic tremor at Brothers Volcano, south Kermadec arc, using an ocean bottom hydrophone array. Journal of Geophysical Research: Solid Earth, 113(B8):B08S04. https://doi.org/10.1029/2007JB005533

Edmond, J.M., Measures, C., McDuff, R.E., Chan, L.H., Collier, R., Grant, B., Gordon, L.I., and Corliss, J.B., 1979. Ridge crest hydrothermal activity and the balances of the major and minor elements in the ocean: the Galapagos data. Earth and Planetary Science Letters, 46(1):1-18. https://doi.org/10.1016/0012-821X(79)90061-X

Embley, R.W., de Ronde, C.E.J., Merle, S.G., Davy, B., and Catatoni Tontini, F., 2012. Detailed morphology and structure of an active submarine arc caldera: Brothers Volcano, Kermadec arc. Economic Geology,107(8):15571570. https://doi.org/10.2113/econgeo.107.8.1557

Fisher, R.V., and Schmincke, H.-U., 1984. Pyroclastic Rocks: Berlin (SpringerVerlag). https://doi.org/10.1007/978-3-642-74864-6

Fryer, P., Wheat, C.G., Williams, T., and the Expedition 366 Scientists, 2018. Mariana Convergent Margin and South Chamorro Seamount. Proceedings of the International Ocean Discovery Program, 366: College Station, TX (International Ocean Discovery Program). https://doi.org/10.14379/iodp.proc.366.2018

Graber, K.K., Pollard, E., Jonasson, B., and Schulte, E. (Eds.), 2002. Technical Note 31: Overview of Ocean Drilling Program engineering tools and hardware. Ocean Drilling Program. https://doi.org/10.2973/odp.tn.31.2002

Graham, I.J., Reyes, A.G., Wright, I.C., Peckett, K.M., Smith, I.E.M., and Arculus, R.J., 2008. Structure and petrology of newly discovered volcanic centers in the northern Kermadec-southern Tofua arc, South Pacific Ocean. Journal of Geophysical Research: Solid Earth, 113(B8):B08S02. https://doi.org/10.1029/2007JB005453

Grant, F.S., and West, G.F., 1965. Interpretation Theory in Applied Geophysics: New York (McGraw-Hill).

Haase, K.M., Stroncik, N., Garbe-Schönberg, D., and Stoffers, P., 2006. Formation of island arc dacite magmas by extreme crystal fractionation: an example from Brothers Seamount, Kermadec island arc (SW Pacific). Journal of Volcanology and Geothermal Research, 152(3-4):316-330. https://doi.org/10.1016/j.jvolgeores.2005.10.010

Hart, S.R., and Staudigel, H., 1982. The control of alkalies and uranium in seawater by ocean crust alteration. Earth and Planetary Science Letters, 58(2):202-212. https://doi.org/10.1016/0012-821X(82)90194-7

Hirose, T., Kawagucci, S., and Suzuki, K., 2011. Mechanoradical $\mathrm{H}_{2}$ generation during simulated faulting: implications for an earthquake-driven subsurface biosphere. Geophysical Research Letters, 38(17):L17303. https://doi.org/10.1029/2011GL048850

Humphris, S.E., and Thompson, G., 1978. Hydrothermal alteration of oceanic basalts by seawater. Geochimica et Cosmochimica Acta, 42(1):107-125. https://doi.org/10.1016/0016-7037(78)90221-1

Kelley, K.A., Plank, T., Ludden, J., and Staudigel, H., 2003. Composition of altered oceanic crust at ODP Sites 801 and 1149. Geochemistry, Geophysics, Geosystems, 4(6)8910. https://doi.org/10.1029/2002GC000435

Kirschvink, J.L., 1980. The least-squares line and plane and the analysis of palaeomagnetic data. Geophysical Journal of the Royal Astronomical Society, 62(3):699-718.

https://doi.org/10.1111/j.1365-246X.1980.tb02601.x
Klein, F., Humphris, S.E., Guo, W., Schubotz, F., Schwarzenbach, E.M., and Orsi, W.D., 2015. Fluid mixing and the deep biosphere of a fossil Lost City-type hydrothermal system at the Iberia Margin. Proceedings of the National Academy of Sciences of the United States of America, 112(39):12036-12041. https://doi.org/10.1073/pnas.1504674112

Kruber, C., Thorseth, I.H., and Pedersen, R.B., 2008. Seafloor alteration of basaltic glass: textures, geochemistry, and endolithic microorganisms. Geochemistry, Geophysics, Geosystems, 9(12):Q12002. https://doi.org/10.1029/2008GC002119

Lever, M.A., Rouxel, O., Alt, J.C., Shimizu, N., Ono, S., Coggon, R.M., Shanks, W.C., III, et al., 2013. Evidence for microbial carbon and sulfur cycling in deeply buried ridge flank basalt. Science, 339(6125):1305-1308. https://doi.org/10.1126/science.1229240

Lurcock, P.C., and Wilson, G.S., 2012. PuffinPlot: a versatile, user-friendly program for paleomagnetic analysis. Geochemistry, Geophysics, Geosystems, 13(6):Q06Z45. https://doi.org/10.1029/2012GC004098

McFadden, P.L., and Reid, A.B., 1982. Analysis of paleomagnetic inclination data. Geophysical Journal of the Royal Astronomical Society, 69(2):307319. https://doi.org/10.1111/j.1365-246X.1982.tb04950.x

O'Reilly, W., 1984. Rock and Mineral Magnetism: New York (Springer US). https://doi.org/10.1007/978-1-4684-8468-7

Özdemir, Ö., and O’Reilly, W., 1982. Magnetic hysteresis properties of synthetic monodomain titanomaghemites. Earth and Planetary Science Letters, 57(2):437-447. https://doi.org/10.1016/0012-821X(82)90162-5

Richter, C., Acton, G., Endris, C., and Radsted, M., 2007. Technical Note 34: Handbook for Shipboard Paleomagnetists. Ocean Drilling Program. https://doi.org/10.2973/odp.tn.34.2007

Shipboard Scientific Party, 2002. Leg 193 summary. In Binns, R.A., Barriga, F.J.A.S., Miller, D.J., et al., Proceedings of the Ocean Drilling Program, Initial Reports, 193: College Station, TX (Ocean Drilling Program). https://doi.org/10.2973/odp.proc.ir.193.101.2002

Tauxe, L., 2010. Essentials of Paleomagnetism: Berkeley, California (University of California Press)

Timm, C., de Ronde, C.E.J., Leybourne, M.I., Layton-Matthews, D., and Graham, I.J., 2012. Sources of chalcophile and siderophile elements in Kermadec arc lavas. Economic Geology, 107(8):1527-1538. https://doi.org/10.2113/econgeo.107.8.1527

Wakita, H., Nakamura, Y., Kita, I., Fujii, N., and Notsu, K., 1980. Hydrogen release: new indicator of fault activity. Science, 210(4466):188-190. https://doi.org/10.1126/science.210.4466.188

Wiersberg, T., and Erzinger, J., 2008. Origin and spatial distribution of gas at seismogenic depths of the San Andreas Fault from drill-mud gas analysis. Applied Geochemistry, 23(6):1675-1690. https://doi.org/10.1016/j.apgeochem.2008.01.012]

Wright, I.C., and Gamble, J.A., 1999. Southern Kermadec submarine caldera arc volcanoes (SW Pacific): caldera formation by effusive and pyroclastic eruption. Marine Geology, 161(2-4):207-227. https://doi.org/10.1016/S0025-3227(99)00040-7

Zijderveld, J.D.A., 1967. AC demagnetization of rocks: analysis of results. In Collinson, D.W., Creer, K.M., and Runcorn, S.K. (Eds.), Developments in Solid Earth Geophysics (Volume 3): Methods in Palaeomagnetism: Amsterdam (Elsevier), 254-286. https://doi.org/10.1016/B978-1-4832-2894-5.50049-5 